LÍVIA CAIRES DOS SANTOS

\title{
PEPTÍDEO C16 REGULA MIGRAÇÃO, INVASÃO, INVADOPÓDIOS E SUAS MOLÉCULAS-CHAVE, BEM COMO GERAÇÃO DE ESPÉCIES REATIVAS DE OXIGÊNIO EM CÉLULAS TUMORAIS PROSTÁTICAS
}

Dissertação apresentada ao Programa de Pós-Graduação em Biologia Celular e Tecidual do Instituto de Ciências Biomédicas da Universidade de São Paulo, para obtenção do Título de Mestre em Ciências.

São Paulo

2014 
LÍVIA CAIRES DOS SANTOS

\section{PEPTÍDEO C16 REGULA MIGRAÇÃO, INVASÃO, INVADOPÓDIOS E SUAS MOLÉCULAS-CHAVE, BEM COMO GERAÇÃO DE ESPÉCIES REATIVAS DE OXIGÊNIO EM CÉLULAS TUMORAIS PROSTÁTICAS}

Dissertação apresentada ao Programa de Pós-Graduação em Biologia Celular e Tecidual do Instituto de Ciências Biomédicas da Universidade de São Paulo, para obtenção do Título de Mestre em Ciências

Área de Concentração: Biologia Celular e Tecidual

Orientador: Prof. Dr. Ruy Gastaldoni Jaeger

Versão original

São Paulo

2014 
DADOS DE CATALOGAÇÃO NA PUBLICAÇÃO (CIP)

Serviço de Biblioteca e Informação Biomédica do Instituto de Ciências Biomédicas da Universidade de São Paulo

reprodução não autorizada pelo autor

Santos, Lívia Caires dos.

Peptídeo $\mathrm{C} 16$ regula migração, invasão, invadopódios e suas moléculas-chave, bem como geração de espécies reativas de oxigênio em células tumorais prostáticas / Lívia Caires dos Santos. -- São Paulo, 2014.

Orientador: Prof. Dr. Ruy Gastaldoni Jaeger.

Dissertação (Mestrado) - Universidade de São Paulo. Instituto de Ciências Biomédicas. Departamento de Biologia Celular e do Desenvolvimento. Área de concentração: Biologia Celular e Tecidual. Linha de pesquisa: O papel da laminina e seus peptídeos bioativos na biologia tumoral.

Versão do título para o inglês: Laminin-derived peptide $C 16$ regulates migration, invasion and invadopodia molecules-Keys, as well as reactive oxygen species generation in prostate cancer cells.

1. Neoplasias prostáticas 2. Matriz extracelular 3. Laminina 4. Peptídeos 5. Invadopódios 6. ROS I. Jaeger, Prof. Dr. Ruy Gastaldoni II. Universidade de São Paulo. Instituto de Ciências Biomédicas. Programa de Pós-Graduação em Biologia Celular e Tecidual III. Título. 
Título da Dissertação:

Peptídeo $\mathrm{C} 16$ regula migração, invasão, invadopódios e suas moléculas-chave, bem como geração de espécies reativas de oxigênio em células tumorais prostáticas.

Orientador(a): $\quad$ Prof. Dr. Ruy Gastaldoni Jaeger.

A Comissão Julgadora dos trabalhos de Defesa da Dissertação de Mestrado, em sessão pública realizada a considerou
( ) Aprovado(a)
( ) Reprovado(a)

Examinador(a): Assinatura:

Nome:

Instituição:

Examinador(a): Assinatura:

Nome:

Instituição:

Presidente: Assinatura:

Nome:

Instituição: 


\section{CERTIFICADO DE ISENÇÃO}

Certificamos que o Protocolo CEP-ICB N $\mathrm{N}^{\circ}$ 536/12 referente ao projeto intitulado: "Peptídeo C16, derivado da laminina-111, regulando expressão das proteinas TKS4 e TKSS em invadopódios em linhagem celular de carcinoma epidermóide," sob a responsabilidade de Lívia Caires dos Santos, foi analisado na presente data pela CEUA COMISSÃO DE ÉTICA NO USO DE ANIMAIS e pela CEPSH- COMISSÃO DE ÉTICA EM PESQUISA COM SERES HUMANOS, tendo sido deliberado que o referido projeto não utilizará animais que estejam sob a égide da lei 11.794 de 8 de outubro de 2008, nem envolverá procedimentos regulados pela Resolução CONEP nº196 de 1996.

São Paulo, 08 de agosto de 2012.

\section{P) Equnes}

Prof. DR. Wothan TAVARES DE LIMA Coordenador da CEUA - ICB/USP

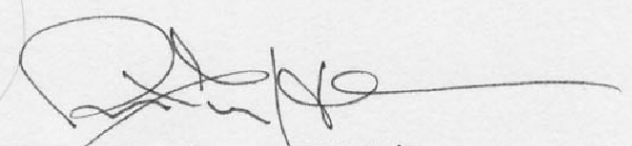

PROF. DR. PAOLO M.A ZaNOTTO

Coordenador da CEPsh - ICB/USP 
Aos meus pais, pelo amor incondicional e constante apoio em toda minha caminhada. Ao meu irmão Rômulo, por sempre estar pronto a me auxiliar com seus sábios conselhos. Amo vocês. 


\section{AGRADECIMENTOS ESPECIAIS}

Ao Prof. Dr. Ruy Gastaldoni Jaeger, por me dar a oportunidade de estar em seu laboratório e assim, desenvolver este trabalho. O senhor me forneceu as ferramentas necessárias para a execução bem feita de um experimento, bem como sua análise e exposição dos resultados. Tudo meticulosamente corrigido e bem feito para sempre garantir a qualidade do que é realizado. Isto reflete sua competência para o trabalho. Os conhecimentos adquiridos com a minha passagem pelo seu Laboratório foram essenciais para minha formação e estarão sempre comigo. Muitíssimo obrigada por tudo.

À Dra. Adriane Sousa de Siqueira, por todo tempo dedicado a me ensinar fazer ciência. Sempre muito organizada, prestativa e de bom humor, me ensinou cada pequeno detalhe para um experimento bem feito. Mas minha admiração vai além da bancada pois, mais do que exemplo de profissional, é também de ser humano. Levarei nossa amizade com muito carinho.

À Profa. Dra. Vanessa Morais Freitas, pela grande colaboração neste trabalho. Agradeço suas sugestões e por sempre estar disponível para responder minhas dúvidas. O apoio técnico de seu Laboratório e de todas as suas alunas foram essenciais para etapas deste trabalho.

Ao Felipe, meu eterno companheiro. Quem cuida de mim com muito carinho e que em todos os momentos, sejam tristes ou felizes, está sempre ao meu lado, vibrando comigo a cada conquista. Este trabalho é resultado de seu apoio e compreensão. Obrigada por fazer parte da minha vida e me deixar fazer parte da sua. 


\section{AGRADECIMENTOS}

À Coordenação de Aperfeiçoamento de Pessoal de Nível Superior (CAPES), pelo suporte financeiro. A concessão da bolsa de Mestrado foi de extrema importância para a minha formação profissional.

Ao Prof. Dr. Hernandes Faustino (Departamento de Biologia Estrutural e Funcional, Instituto de Biologia, UNICAMP, SP), por ter cedido a linhagem DU145 utilizada neste trabalho.

À Profa. Telma Zorn e sua equipe, por toda atenção dada ao nosso Laboratório e por ceder parte de seu espaço para realizarmos experimentos de cultura de células.

Às Profa. Dra. Marinilce Fagundes Santos, Profa. Dra. Patrícia Gama e Profa. Dra. Claudimara Lofti pelas sugestões dadas ao meu trabalho no exame de Qualificação.

À Monique Rodrigues, por ter me ensinado fazer "immunoblot", o experimento com mais minúcias que aprendi até agora. Obrigada pela paciência e por ter sido tão prestativa. Sou muito grata também pelas nossas inúmeras conversas além do Laboratório, com muitos conselhos e risadas.

Às amigas Heydi, Maira, Suély e Thaiomara, do Laboratório da Profa. Vanessa Freitas, agradeço pela constante ajuda que recebi de vocês quando precisei de algo do Laboratório. E também pelas inúmeras conversas e risadas durante almoços e cafés.

Ao Basílio Smuckez, foi a mais grata surpresa ter encontrado você no Laboratório. Meu companheiro de experimentos, conversas, desabafos, sempre me auxiliando da melhor maneira possível e com um incrível bom humor. Uma pessoa muito querida que levarei para sempre com muito carinho. Sei que ainda tem muito trabalho pela frente, com um futuro brilhante para você. 
Às minhas amigas de longa data que sempre me apoiaram neste trabalho $\mathrm{e}$ fazem parte da minha história. Alyne, Carolina, Bárbara, Débora, Marianne e Ana Cláudia. 


\section{RESUMO}

SANTOS, L. C. Peptídeo C16 regula migração, invasão, invadopódios e suas moléculas-chave, bem como geração de espécies reativas de oxigênio em células tumorais prostáticas. 2014. 90 f. Dissertação (Mestrado em Biologia Celular e Tecidual) - Instituto de Ciências Biomédicas, Universidade de São Paulo, São Paulo, 2014.

O câncer de próstata é o segundo câncer mais freqüentemente diagnosticado e a sexta maior causa de morte por câncer em homens. Durante o crescimento tumoral, as células neoplásicas interagem com a matriz extracelular (MEC) e este evento influencia a biologia tumoral. A laminina é uma molécula expressa de forma proeminente na matriz extracelular, sendo reguladora chave de diferentes tumores. Nosso Laboratório demonstrou que os peptídeos derivados da clivagem da laminina estão envolvidos na migração, invasão e formação de invadopódios em diferentes linhagens tumorais. Os invadopódios são caracterizados como protrusões de membrana ricas em actina e proteínas moduladoras de actina. A atividade dos invadopódios é dependente da expressão das proteínas Tks4, Tks5, cortactina e MT1-MMP e da geração de ROS. Neste trabalho, analisamos o efeito de C16, um peptídeo derivado da laminina, sobre a migração, invasão e regulação da atividade dos invadopódios em células de câncer de próstata (DU145). Os ensaios de migração demonstraram que $\mathrm{C} 16$ promoveu um aumento da atividade migratória de células DU145 de maneira dose dependente em comparação com células tratadas com C16SX (peptídeo controle). C16 também aumentou a taxa de invasão de células DU145 de forma dose dependente. A seguir, buscamos vias de sinalização relacionadas aos efeitos de $\mathrm{C} 16 \mathrm{em}$ células tumorais, e demonstramos que o peptídeo estimula a fosforilação de Src. Sabe-se que migração e invasão estão relacionados com a expressão de proteases e atividade de invadópodios. Ensaios de degradação em substrato fluorescente mostraram que C16 promoveu a formação de invadopódios de células DU145. O immunoblot nos revelou que este peptídeo também estimula a expressão de Tks4, Tks5, cortactina e MT1-MMP. Essas moléculas são marcadores chaves dos invadopódios. Além disso, C16 estimulou a produção de espécies reativas de oxigênio, importantes para o fenótipo invasivo das células tumorais. Nossos resultados sugerem que o peptídeo C16 regula migração, invasão, invadopódios e suas moléculas-chave, bem como geração de espécies reativas de oxigênio em células tumorais prostáticas (DU145).

Palavras-chaves: Câncer prostático. Invadopódios. Matriz Extracelular. Laminina. Tks. Espécies Reativas de Oxigênio. 


\begin{abstract}
SANTOS, L. C. Laminin-derived peptide C16 regulates migration, invasion, invadopodia key-molecules, and ROS generation in human prostate cancer cells. 2014. 90 p. Masters thesis (Cell and Tissue Biology) - Instituto de Ciências Biomédicas, Universidade de São Paulo, São Paulo, 2014.

Prostate cancer is the second most frequently diagnosed cancer and sixth leading cause of cancer death in males. During tumor growth, neoplastic cells interact with the extracellular matrix (ECM) and this interaction influences tumor biology. Laminin is a molecule prominently expressed in ECM, and a key regulator of different tumors. Our Laboratory has demonstrated that peptides derived from laminin-111 cleavage are involved in migration, invasion and invadopodia formation in different tumor cell lines. Invadopodia are membrane protrusions made up by actin and actin-binding proteins. Invadopodia activity depends on expression of the proteins Tks4, Tks5, cortactin, MT1-MMP, as well as reactive oxygen species (ROS) generation. Here we analyzed the effect of $\mathrm{C} 16$, a laminin-derived peptide, on migration, invasion and invadopodia activity in human prostate cancer cells (DU145). Migration assays in chemotaxis chambers demonstrated that C16 increased migration activity of DU145 cells in a dose-dependent manner compared to cells grown on C16SX (scrambled control peptide). C16 also increased invasion of DU145 cells in dose-dependent manner. Next, we addressed signaling pathways related to C16 effects in tumor cells, and observed that the peptide stimulated phosphorylation of Src. Migration and invasion are related to protease expression and invadopodia activity. Fluorescent substrate degradation assay showed that $\mathrm{C} 16$ increased invadopodia activity of DU145 cells. Immunoblot revealed that this peptide stimulated Tks4, Tks5, cortactin and MT1-MMP expression in a dose-dependent manner. Furthermore, C16 increased ROS production. Our results strongly suggested that laminin peptide $\mathrm{C} 16$ regulates migration, invasion, invadopodia key-molecules, and ROS generation in human prostate cancer cells (DU145).
\end{abstract}

Keywords: Prostate cancer. Invadopodia. Extracellular Matrix. Laminin. Tks. Reactive Oxygen Species. 


\section{LISTA DE DIAGRAMAS}

Diagrama 2.4.1 - Esquema ilustrativo das moléculas Tks4 e Tks5................ 37

Diagrama 2.4.2 - Fases de formação dos invadopódios............................. 39 


\section{LISTA DE TABELA}

Tabela 4.1: Sequência de aminoácidos dos peptídeos C16 e C16SX............................... 42 


\section{LISTA DE ILUSTRAÇÕES}

Figura 5.1 - Peptídeo C16 estimula as atividades migratória e invasiva de células

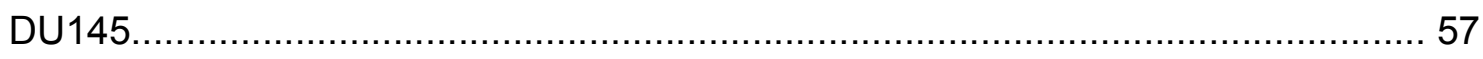

Figura 5.2 - C16 estimula a atividade de invadopódios e a expressão de Tks5 em células DU145. Via Src pode estar relacionada com os eventos............................. 59

Figura 5.3 - O peptídeo C16 estimula a expressão de Tks4 e MT1-MMP de células

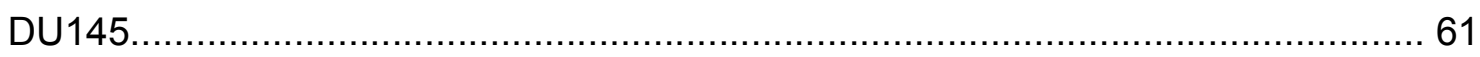

Figura 5.4 - O peptídeo C16 estimula a expressão de cortactina e Tks5................ 63 Figura 5.5 - O peptídeo C16 modula a produção de espécies reativas de oxigênio

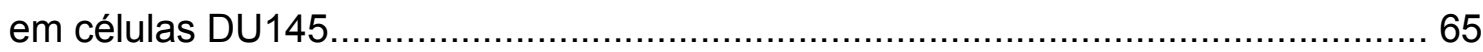




\section{LISTA DE ABREVIATURAS E SIGLAS}

ADAMs do inglês "a disintegrin and metalloproteases", traduzido como uma desintegrina e metaloproteinase

AG73 sequência dos aminoácidos RKRLQVQLSIRT (arginina-lisina-argininaleucina-glicina-valina-glicina-leucina-serina-isoleucina-argininatreonina)

BCA do inglês "Bicinchoninic Acid", traduzido ácido bicinconínico

BSA do inglês "Bovine Serum Albumine", traduzido como albumina sérica bovina

C16 sequência dos aminoácidos KAFDITYVRLKF (lisina-asparaginafenilalanina-ác.aspártico-isoleucina-treonina-tirosina-valina-argininaleucina-lisina-fenilalanina)

CCD do inglês "charge-coupled device" traduzido como dispositivo de carga acoplada

$\mathrm{CO}_{2} \quad$ gás carbônico

DMEM/F-12 do inglês "Dulbecco's Modified Eagles' Medium with Nutrient Mixture F12", traduzido como meio de Eagle modificado por Dulbecco suplementado por nutriente F12

DU145 linhagem celular derivada de carcinoma prostático

ECL do inglês "enhanced chemiluminescence"

EDTA do inglês "ethylenediamine-tetra acetic acid", traduzido como ácido etilenodiamino tetra acético

EHS Engelbreth-Holm-Swarm

FAK do inglês "focal adhesion kinase", traduzido como quinase de adesão focal

FITC do inglês "Fluorescein isothiocyanate", traduzido como isotiocianato de fluoresceína

kDa kilodalton

M molar

MEC matriz extracelular

mg miligrama

$\mathrm{ml} \quad$ mililitro

$\mathrm{mm} \quad$ milímetro 
MMPs do inglês "matrix metalloproteinases" traduzido como metaloproteinase de matriz

MT1-MMP do inglês "membrane-type 1 matrix metalloproteinase", traduzido como metaloproteinase de matriz ancorada a membrana 1

NADPH do inglês "nicotinamide adenine dinucleotide phosphate-oxidase", traduzido como nicotinamida adenina dinucleotídeo fosfato

ng nanograma

nm nanômetro

OMS Organização Mundial da Saúde

$\mathrm{pH} \quad$ potencial hidrogeniônico

$\mathrm{PI}(3,4) \mathrm{P} 2$ fosfatidilinositol-3-4-bifosfato

PSA do inglês "prostate-specific antigen”, traduzido como antígeno prostático específico

ROS do inglês "reactive oxygen species", traduzido como espécies reativas de oxigênio

RP-HPLC do inglês "reversed-phase high-pressure iquid chromatography", traduzido como cromatografia líquida de alta resolução em fase reversa

SBF $\quad$ Soro fetal bovino

SDS-PAGE do inglês "sodium dodecyl sulfate polyacrylamide gel eletrophoresis", traduzido como eletroforese de gel de poliacrilamida, tendo como agente denaturante sulfato dodecil

SH3 do inglês "Src homology 3 domain", traduzido como domínio Src 3 homólogo

TBS do inglês "Tris-buffered saline", traduzido como tampão tris-salina

Tks do inglês “ Tyrosine kinase substrate”, traduzido como substrato de tirosina quinase

UV ultravioleta

WASp do inglês "Wiskott-Aldrich Syndrome protein", traduzido como proteína da síndrome de Wiskott-Aldrich 


\section{SUMÁRIO}

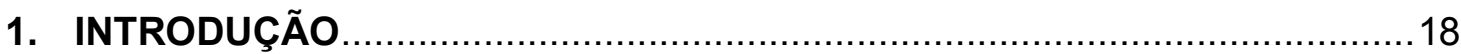

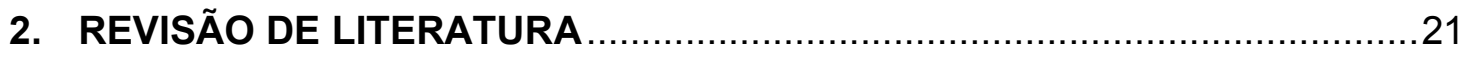

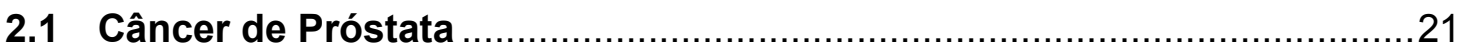

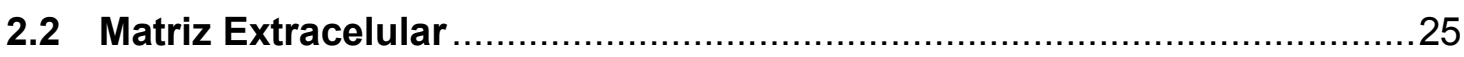

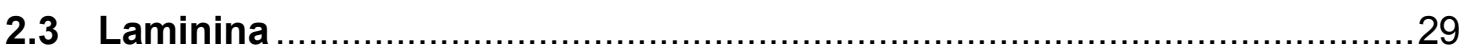

2.3.1 Laminina-111 e o peptídeo bioativo derivado ................................... 31

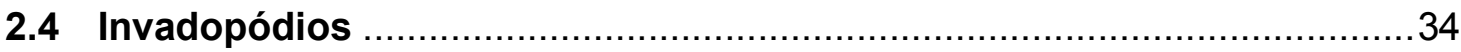

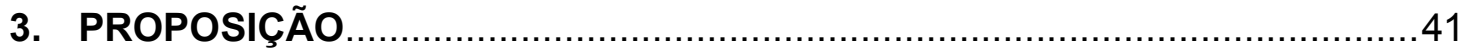

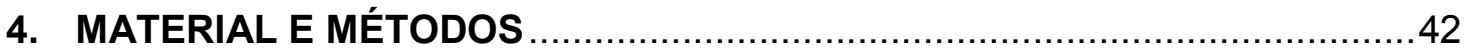

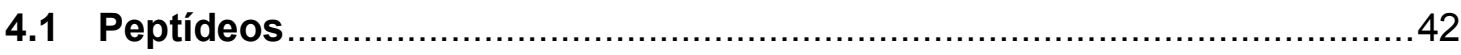

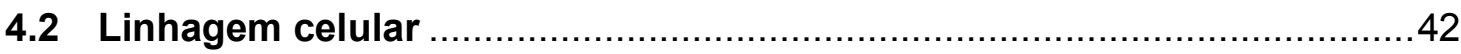

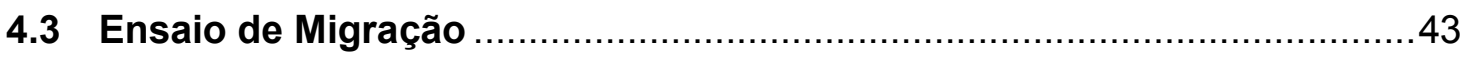

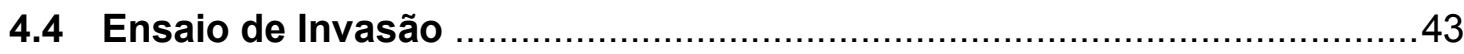

4.5 Determinação de invadopódios em células DU145 tratadas pelo peptídeo C16 crescidas sobre substrato fluorescente ........................................44

4.5.1 Preparo do Substrato Fluorescente ...................................................44

4.5.2 Ensaio de Degradação em Substrato Fluorescente ................................44

4.5.3 Microscopia e Análise das Imagens .................................................. 45

4.6 Estudo de proteínas relacionadas à formação de invadopódios em células DU145 tratadas pelo peptídeo C16 .........................................46

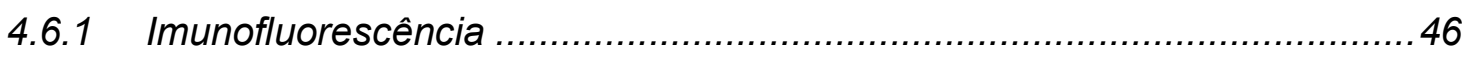

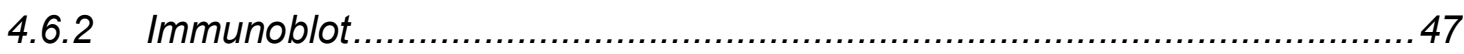

4.6.3 Imunoprecipitação .............................................................. 48

4.7 Via de sinalização relacionada aos efeitos de C16 ............................49

4.8 Peptídeo C16 e produção de espécies reativas de oxigênio ....................49

4.8.1 Mensuração da intensidade de fluorescência.........................................49

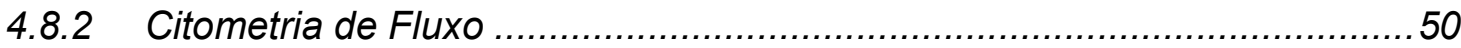

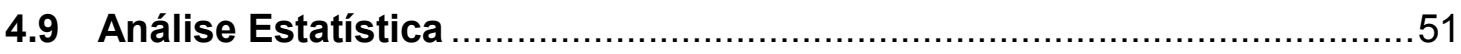

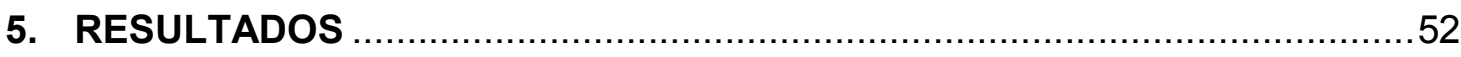

5.1 Peptídeo C16 estimula atividades migratória e invasiva de células

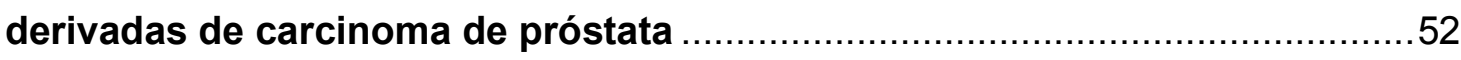


5.2 Peptídeo C16 estimula atividade de invadopódios e a expressão de Tks5 em células DU145. Via Src pode estar relacionada aos eventos ....................52

5.3 Peptídeo C16 estimula a expressão de MT1-MMP e Tks4 .....................53

5.4 Peptídeo C16 estimula a expressão de cortactina e Tks5........................54

5.5 C16 modula a formação de espécies reativas de oxigênio em derivadas

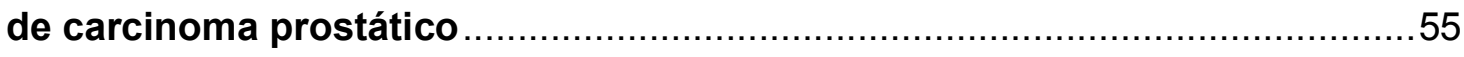

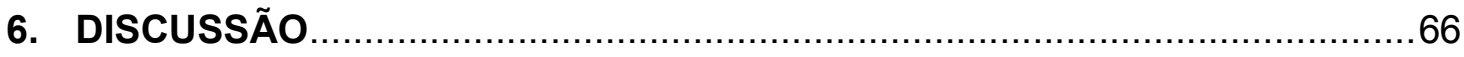

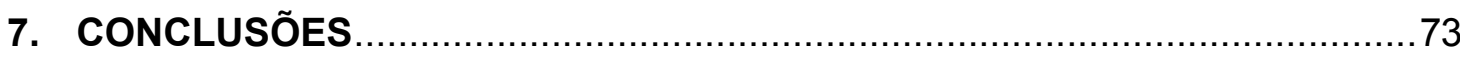

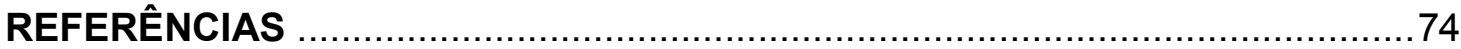




\section{INTRODUÇÃO}

Dentre os tumores que acometem a população masculina no Brasil, o câncer de próstata é o segundo mais prevalente, atrás apenas dos tumores de pele nãomelanoma (INSTITUTO NACIONAL DO CÂNCER, 2014). Dados da Organização Mundial da Saúde (ORGANIZAÇÃO MUNDIAL DA SAÚDE, 2013) mostram que em 2013, aproximadamente 900 mil novos casos foram diagnosticados no mundo, com altas taxas em países desenvolvidos da América do Norte, do Sul e Europa. A idade avançada é o principal fator etiológico, porém, o histórico familiar da doença, alimentação não saudável, consumo excessivo de álcool, tabagismo e exposição à pesticida também perfazem um cenário crítico para o desenvolvimento da neoplasia (GOMELLA et al., 2011; KOUTROS et al., 2013a; KOUTROS et al., 2013b).

O microambiente onde as células do carcinoma de próstata se encontram pode desempenhar papel fundamental na tumorigênese e progressão tumoral. Este microambiente é formado não somente pelo componente maligno epitelial, mas também por estroma circundante e tecido normal. Desse modo, as células neoplásicas, durante o desenvolvimento tumoral, interagem com outros tecidos e com a matriz extracelular (MEC) (MEHROTRA; YADAV, 2006; RUFFELL et al., 2012).

Em tecidos como o epitélio, a MEC forma uma fina camada altamente especializada, chamada lâmina basal, que participa dos processos de adesão, migração, crescimento e diferenciação celulares. Componentes estruturais da lâmina basal incluem colágeno tipo IV, nidogênio, proteoglicanas e lamininas (YURCHENCO; AMENTA; PATTON, 2004). Um evento fundamental para a invasão das células tumorais é proteólise da lâmina basal e seus respectivos componentes. Este processo ocasiona alterações na composição estrutural e conteúdo proteico e está relacionada à capacidade invasiva de tumores malignos (GHOSH; STACK, 2000).

Peptídeos derivados da clivagem da laminina já foram identificados e associados com progressão do câncer. Trabalhos realizados em nosso Laboratório mostraram que diferentes peptídeos da laminina-111 (antiga laminina-1) têm capacidade de regular funções em linhagens celulares derivadas de neoplasias benignas e malignas de glândula salivar (CAPUANO; JAEGER, 2004; FREITAS; JAEGER, 2002; FREITAS et al., 2004; FREITAS et al., 2007; GAMA-DE-SOUZA et 
al., 2008; SIQUEIRA et al., 2010). Dentre eles, o peptídeo C16 (KAFDITYVRLKF), derivado da cadeia $\gamma 1$ estimula migração, invasão e atividade proteolítica em células derivadas de carcinoma adenoide cístico (GAMA-DE-SOUZA et al., 2008). Em trabalhos mais recentes de nosso grupo, verificamos ainda que os peptídeos C16 e AG73, esse último derivado da cadeia $\alpha 1$ da laminina, estão relacionados ao aumento da atividade de invadopódios em células de carcinoma adenoide cístico e de carcinoma epidermóide através do receptor integrina $\beta 1$ (NASCIMENTO et al., 2011; SIQUEIRA et al., 2010; SIQUEIRA, 2014).

O processo metastático consiste na disseminação de células tumorais fora de seu sítio primário de desenvolvimento. Para que a célula neoplásica se desloque, se fazem necessários alguns eventos como perda de contato célula-célula, remodelamento de sítios de adesão célula-matriz e secreção de proteases para degradação da matriz extracelular (GRUNERT; JECHLINGER; BEUG, 2003). Dentre os mecanismos envolvidos para que estes eventos ocorram, podemos citar a formação de invadopódios e sua ação sobre a matriz. Os invadopódios são estruturas que possuem atividade de degradação da matriz extracelular e são encontradas em células tumorais malignas (ARTYM et al., 2006; AYALA et al., 2006; BRYCE et al., 2005; BUCCIONE; ORTH; MCNIVEN, 2004; CLARK; WEAVER, 2008; CLARK et al., 2007). São protrusões de membrana ricas em microfilamentos de actina que se formam no ventre das células, estendendo-se verticalmente para a MEC. Essas protrusões são formadas ainda por proteínas de adesão e proteínas estruturais, proteases de matriz e moléculas sinalizadoras, as quais regulam o citoesqueleto de actina e remodelação da membrana.

Dentre as moléculas que desempenham papel importante na progressão tumoral e na regulação dos invadopódios, podemos destacar Tks4 e Tks5 (YAMAGUCHI; OIKAWA, 2010). São substratos de tirosina quinase, com 4 e 5 domínios SH3 respectivamente (MURPHY; COURTNEIDGE, 2011). São proteínas adaptadoras que se encontram distribuídas pelo citoplasma em situação fisiológica, mas no processo de tumorigênese situam-se na membrana plasmática e nos invadopódios de células tumorais e de fibroblastos Src-transformados (DIAZ et al., 2009; SEALS et al., 2005). Estas moléculas mostraram ter relevância na atividade de invadopódios, degradação da matriz extracelular e no crescimento tumoral in vivo (BUCCIONE; CALDIERI; AYALA, 2009). Tks5 é expressa logo nos primeiros estágios de formação dos invadopódios, participando 
na elongação da estrutura e estando associada à cortactina. Já Tks4 é responsável por regular a localização, a secreção e a estabilização de metaloproteinases de membrana, MT1-MMP (BUCCIONE; CALDIERI; AYALA, 2009). Adicionalmente, Tks4 como Tks5 são relacionados com a formação de espécies reativas de oxigênio ("reative oxygen species" - ROS) (MURPHY; COURTNEIDGE, 2011). Dessa forma seria interessante analisar se um eventual aumento da expressão de Tks4 ou 5 induzido por C16 seria acompanhado por aumento produção de ROS.

Diante da importância da interação das células tumorais prostáticas com seu microambiente, nossa proposta nesta etapa do projeto foi avaliar se o peptídeo C16 regularia a migração, a invasão e a expressão de proteínas relacionadas aos invadopódios na linhagem celular DU145. 


\section{REVISÃO DE LITERATURA}

$\mathrm{Na}$ revisão de literatura, abordaremos os seguintes temas relacionados a esta tese: 1) Carcinoma Prostático, doença de interesse nesse estudo; 2) Conceitos sobre matriz extracelular e lâmina basal, destacando a laminina e suas atividades biológicas; 3) Peptídeos bioativos derivados da laminina, com enfoque ao peptídeo C16; e 4) Invadopódios, estruturas relacionadas à invasão celular.

\subsection{Câncer de Próstata}

Dentre os tumores que acometem a população masculina no Brasil, o câncer de próstata é o segundo mais prevalente, atrás apenas dos tumores de pele nãomelanoma. Estimativas apontam o surgimento de 69 mil novos casos da doença para o ano de 2014 (INCA, 2014). Dados da Organização Mundial da Saúde (OMS, 2013) mostram que em 2013, aproximadamente 900 mil novos casos foram diagnosticados no mundo com altas taxas em países desenvolvidos da América do Norte, do Sul e Europa, enquanto países asiáticos apresentam menores taxas de incidência.

A etiologia do câncer de próstata ainda não é totalmente esclarecida. Entretanto, presume-se que a idade avançada seja um dos principais fatores que influenciam no desenvolvimento da neoplasia (GOMELLA et al., 2011). A idade média para o diagnóstico da doença é de 65 anos (STANGELBERGER; WALDERT; DJAVAN, 2008). Adicionalmente, estudos clínicos mostram que a dieta rica em carne vermelha, consumo excessivo de álcool, tabagismo e exposição à pesticida também perfazem um cenário crítico para o desenvolvimento da neoplasia (KOUTROS et al., 2013a; MANDAIR et al., 2014).

Além dos fatores apresentados, outro importante ponto a ser levado em consideração é o histórico familiar (DEMICHELIS; STANFORD, 2014; HELFAND; CATALONA, 2014). O risco de desenvolvimento da neoplasia prostática é aumentado quando um familiar é acometido pela doença, sendo a proximidade de parentesco um potencializador do quadro. Isto é uma forte evidência do envolvimento genético na doença familiar (EDWARDS; EELES, 2004). Estudos 
realizados envolvendo os genes BRCA1 e BRCA2 relatam que estes estão mutados em $1 \%$ e $5 \%$ dos cânceres de próstata, respectivamente. Porém, a mutação genética que influencia de forma relevante esse quadro familiar ainda não está completamente elucidada (CASTRO; EELES, 2012; ISAACS, 2012; NAKAGAWA, 2011).

A próstata é um órgão glandular retroperitoneal que se encontra próximo ao colo da bexiga e circunda parte da uretra masculina, pesando em torno de 20 gramas em adultos normais. Anatomicamente é divida em quatro zonas distintas: periférica, central, de transição e fibromuscular anterior (estroma) (NASKAR et al., 2014). Sua principal função é de armazenamento e secreção de um fluido claro que, junto aos espermatozoides produzidos nos testículos, constituem o semêm, fundamental na fertilização (MURASHIMA et al., 2014).

Cerca de $70 \%$ das malignidades prostáticas acometem a zona periférica do órgão (GINSBURG et al., 2014). Os tumores são tipicamente adenocarcinoma acinar, porém uma minoria é classificada como forma variante por possuir algumas diferenças histológicas, como características de um carcinoma ductal (HUMPHREY, 2012a, b). Na maioria dos casos, o tecido prostático tumoral removido apresenta lesões precursoras chamadas de neoplasia prostática intra-epitelial (PIN). Estas lesões consistem em glândulas prostáticas benignas com proliferações de células intra-acinares que demonstram anaplasia nuclear, o que sugere a formação do câncer a partir destas lesões (HUMPHREY, 2012b).

A incidência do câncer de próstata vem aumentando ao longo dos anos. Esse aumento está associado com a longevidade dos homens e principalmente com melhoria dos métodos diagnósticos para a detecção do tumor (EDWARDS; EELES, 2004). Para American Cancer Society, tem-se como ideal o início do rastreamento do câncer de próstata a partir dos 50 anos, quando não há histórico familiar. Havendo a ocorrência de caso na família, a investigação inicia-se a partir dos 40 anos.

O antígeno prostático específico (PSA) é amplamente utilizado para detecção precoce do tumor de próstata (HONG et al., 2012). Foi introduzido como biomarcador tumoral em meados da década 80 e teve papel fundamental na epidemiologia desta neoplasia. O teste foi inicialmente introduzido em países desenvolvidos e a exemplo, em 1990, os Estados Unidos tiveram um pico de 
incidência de tumor de próstata, evidenciando a importância do rastreamento (CROCETTI et al., 2013; FRITZ et al., 2013; SCHRODER, 2012).

PSA é uma glicoproteína produzida através de regulação androgênica pelas células luminais do epitélio prostático (DIAMANDIS; YOUSEF, 2001) sendo responsável por liquefazer o sêmen após a ejaculação (BRYANT et al., 2014; LILJA, 1985). A arquitetura prostática faz com que o PSA não circule pelo sangue, ficando confinada apenas no órgão, sendo no líquido seminal sua concentração 100 vezes maior do que no plasma. As elevações séricas no plasma são decorrentes da desestruturação do parênquima prostático por alguma desordem, como o desenvolvimento neoplásico. O valor de referência para o PSA total é de $<4,0 \mathrm{ng} / \mathrm{ml}$ (FARIA et al., 2012; STEUBER; O'BRIEN; LILJA, 2008).

O PSA é considerado um marcador órgão específico, porém não se pode afirmar ser tumor específico. Não apenas a neoplasia, mas prostatite e hiperplasia prostática benigna podem alterar os níveis de plasmáticos de PSA. O valor de PSA total não é exclusivo para se indicar prontamente uma biópsia prostática. Sugere-se levar em consideração parâmetros como a idade, a cinética do PSA e a relação de PSA livre sobre PSA total (HAMELIN-PEYRON et al., 2014). Um dos principais focos das recentes pesquisas urológicas é identificação de biomarcadores que sejam clinicamente significativos e específicos para o câncer de próstata (STANGELBERGER; SCHALLY; DJAVAN, 2008).

Outro método diagnóstico largamente utilizado é o exame digital retal (DRE) (FARIA et al., 2012). Apesar do preconceito e resistência na realização do exame, ele tem papel fundamental no rastreamento tumoral. No DRE, consegue-se detectar anormalidades na textura e no tamanho e a presença de nódulos prostáticos. Estes achados clínicos, associados ao exame de PSA total elevado, são preditivos para solicitação de biópsia (CARDOSO et al., 2008; ELSHAFEl et al., 2014; FARIA et al., 2012; LUCIANI et al., 2006).

A biópsia da próstata é realizada com o auxílio do exame de imagem de ultrassom transretal (TRUS). Este auxilia atingir com mais precisão a próstata e não comprometer estruturas próximas. Além disso, permite uma melhor visualização do tamanho do órgão e localização do tumor, sendo também uma ferramenta no rastreamento neoplásico. Além do ultrassom, a ressonância magnética é amplamente utilizada para acompanhar o crescimento tumoral após sua detecção. $A$ sua mais recente aplicação, chamada Ressonância Magnética de Difusão, está 
sendo muito utilizada por ser um exame não invasivo que permite diferenciar tecidos benignos de malignos e transmite informações mais precisas sobre a localização, tamanho, área atingida e agressividade do tumor (CHOl et al., 2007; GHAFOORI; ALAVI; ALIYARI GHASABEH, 2013).

As biópsias histopatológicas dos tumores de próstata seguem o Sistema Gleason de classificação. As neoplasias prostáticas são estratificadas em cinco graus com base nos padrões glandulares e grau de diferenciação celular (DELAHUNT et al., 2012). O grau 1 consiste em células bem diferenciadas, com glândulas uniformes e redondas, agrupadas em nódulos circunscritos sem invasão no tecido adjacente. Segue-se então, nos graus subsequentes, a gradativa perda de diferenciação celular. No grau 5, os tumores não apresentam diferenciação glandular e as células tumorais infiltram o estroma na forma de cordões, folhetos ou ninhos (REESE et al., 2012).

A maioria dos tumores possui mais de um padrão histológico. Para o padrão dominante é designado um grau primário e para o padrão subdominante um grau secundário. Os dois graus numéricos obtidos a partir do padrão dominante e do padrão subdominante são somados e têm-se o Score de Gleason, que pode variar de 2 a 10 (EPSTEIN et al., 2005). Este Score tem um papel importante no prognóstico da doença e na escolha de seu tratamento (EPSTEIN et al., 1996).

O desenvolvimento e manutenção normais da próstata são dependentes de hormônios andrógenos e seu mecanismo de ação se dá através da ligação aos receptores androgênicos nucleares (AR) (KOOCHEKPOUR, 2014). A testosterona é principal hormônio androgênico presente no homem e é produzida pelos testículos e glândulas adrenais (KAHN; COLLAZO; KYPRIANOU, 2014). Sabe-se que no início e em estágios intermediários de desenvolvimento, a grande maioria dos cânceres de próstata também é andrógeno/AR dependente. O tratamento inicial e principal contra o câncer de próstata é a terapia de privação de andrógenos (ADT). Este tratamento tem como objetivo impedir a ligação da testosterona circulante com os AR para não promover o crescimento tumoral (KOOCHEKPOUR, 2014; MOSTAGHEL et al., 2014).

Porém, sabe-se que o tumor de próstata é heterogêneo em sua composição. Eventos moleculares como superexpressão ou mutações nos ARs, podem fazer com que paciente não seja mais responsivo ao tratamento ADT e tenha um reincidiva (KAHN; COLLAZO; KYPRIANOU, 2014). Este quadro demonstra a evolução e 
agressividade do tumor, sendo um ruim prognóstico. A castração é tida como tratamento complementar a ADT e consiste na retirada cirúrgica dos testículos (orquiectomia) para que não haja mais a produção e, consequentemente, a ligação da testosterona com os ARs e assim, cesse o crescimento tumoral. Outras formas de tratamento são a radioterapia, retirada cirúrgica do tecido tumoral ou até mesmo de toda próstata (prostatectomia) em casos mais graves (FIANDALO; WILTON; MOHLER, 2014; IRELLI et al., 2014; MILECKI et al., 2014).

Além das mudanças moleculares das células neoplásicas como ativação de proto-oncogenes e superexpressão de ARs, expressão de fatores de crescimento, atividade imunológica e a regulação homeostática de células normais circundantes também participam do desenvolvimento e progressão do câncer de próstata (KAHN; COLLAZO; KYPRIANOU, 2014; KOOCHEKPOUR, 2014). Por este motivo, é cada vez mais aceita a ideia de que o microambiente relacionado a esta neoplasia não envolve só o componente maligno epitelial, mas também o estroma circundante. Desse modo, o crescimento e a progressão envolvem interações das células tumorais com células de outros tecidos e com a matriz extracelular (GONG; CHIPPADA-VENKATA; OH, 2014).

Para uma melhor compreensão da relação entre o câncer de próstata e a matriz extracelular, faremos uma breve descrição de sua estrutura, componentes e funções.

\subsection{Matriz Extracelular}

Os componentes do estroma prostático consistem em células musculares lisas, fibroblastos, miofibroblastos, células endoteliais e células inflamatórias dispostas em uma rede tridimensional e complexa conhecida como matriz extracelular (MEC) (ELLEM; DE-JUAN-PARDO; RISBRIDGER, 2014).

Estruturalmente, a matriz extracelular é composta por proteínas fibrosas, glicoproteínas adesivas, glicosaminoglicanos (GAGs), proteoglicanos e proteínas especializadas, incluindo fatores de crescimento (DALEY; PETERS; LARSEN, 2008), enzimas proteolíticas, citocinas e outras moléculas regulatórias (LUKASHEV; WERB, 1998). As macromoléculas da matriz extracelular são sintetizadas localmente pelas células do parênquima ou do estroma e estão em contínua comunicação com 
o meio externo através da superfície celular (TANZER, 2006; ZIOBER; FALLS; ZIOBER, 2006).

A MEC não funciona apenas como um suporte estrutural para elementos celulares do estroma e pode influenciar o comportamento celular afetando crescimento, diferenciação, motilidade e viabilidade (FRANTZ; STEWART; WEAVER, 2010; HYNES, 2009; LU; WEAVER; WERB, 2012; STEWART; COOPER; SIKES, 2004; TANZER, 2006; WEAVER, 2009). Moléculas da MEC podem atuar como reservatório de substâncias secretadas pelas células, incluindo fatores de crescimento, citocinas e metaloproteinases da matriz (MMPs). Disponibilidade dessas substâncias para as células pode ser regulada através de rearranjos da matriz, como os que ocorrem, por exemplo, durante os processos de cicatrização e de invasão de tumores malignos (MARASTONI et al., 2008; MILES; SIKES, 2014).

A matriz extracelular pode ser dividida em matriz intersticial e membrana basal. As principais características desses dois domínios é a sua estrutura básica definida por um esqueleto de colágeno, onde suas moléculas são bastante diferentes. A matriz intersticial apresenta colágenos tipicamente fibrilares, como colágeno I (BIRK; MAYNE, 1997; BOSMAN; STAMENKOVIC, 2003; KADLER et al., 1996). Já membrana basal é formada por colágeno IV, isoforma especializada em formar redes. As glicoproteínas adesivas, incluindo a laminina, e os proteoglicanos aderem ao esqueleto de colágeno e interagem com as células localizadas na matriz ou adjacentes a ela (BORNSTEIN, 2002).

A membrana basal é uma estrutura especializada da matriz extracelular. É uma fina camada de proteínas extracelulares que possuem íntimo contato com as células de vários tecidos. Além de situar-se adjacente às células, como as do mesotélio, músculos, células de Schwann e adipócitos (YURCHENCO et al., 2004; YURCHENCO; WADSWORTH, 2004b). É constituída predominantemente por: 1) colágeno tipo IV, um polímero não fibroso; 2) laminina, glicoproteína adesiva; 3) fibronectina; 4) nidogênio (entactina) e 5) perlecan, uma proteglicana. Pequenas quantidades de outras proteoglicanas e glicoproteínas também podem ser encontradas (AUMAILLEY; SMYTH, 1998; COLOGNATO; YURCHENCO, 2000; MAO; SCHWARZBAUER, 2005; SASAKI; FASSLER; HOHENESTER, 2004). Estudos de reconstrução mostraram que, durante o processo de organização da membrana basal, o colágeno tipo IV sofre polimerização e forma um arcabouço que é reconhecido pela laminina, nidogênio e perlecan. Outras moléculas posteriormente 
conectam-se a esta estrutura, criando uma rede interligada que se torna resistente e insolúvel (TANZER, 2006). Em relação à ultraestrutura, não existem diferenças de arquitetura significantes entre membranas basais de vários órgãos e tecidos (AUMAILLEY; SMYTH, 1998; BOSMAN; STAMENKOVIC, 2003; COLOGNATO; YURCHENCO, 2000). Os componentes da lâmina basal do tecido prostático são similares aos de outros órgãos, sendo uma fina camada de $80 \mathrm{~nm}$ tendo como principais componentes: colágeno tipo IV, entactina, laminina e proteoglicanos, em especial o ácido hialurônico (HA) (KNOX et al., 1994). O HA mantém a hidratação e o balanço osmótico da estrutura (TAMMI; DAY; TURLEY, 2002).

A membrana basal serve como um filtro para grandes solutos e é impenetrável para a maioria das células no tecido adulto (TANZER, 2006). Por isso, ela representa o primeiro obstáculo a ser atravessado pelas células neoplásicas durante o processo de invasão. No entanto, as células tumorais desenvolvem mecanismo que as permitem ultrapassar a barreira e migrar para o estroma circundante (BOSMAN et al., 1992; TANZER, 2006).

Para que possam disseminar-se e invadir outras estruturas, células neoplásicas sofrem mudanças que afetam sua morfologia, comportamento, e relação com a matriz extracelular e lâmina basal (MILES; SIKES, 2014; TANZER, 2006). Neste sentido, são capazes não só de promover a ruptura da lâmina basal e abrir caminho para sua migração, mas também de modificar a composição da matriz, alterando o nível de expressão de diferentes proteínas, ou promovendo degradação de diversos componentes. Estes eventos são em grande parte mediados por enzimas proteolíticas, como as metaloproteinases de matriz (MMPs) (EDWARDS, 2008; MOTT; WERB, 2004; ROWE; WEISS, 2009; SCHENK; QUARANTA, 2003; STERNLICHT; WERB, 2001).

As MMPs constituem uma família evolutivamente conservada formada por mais de 25 endopeptidases dependentes de zinco, capazes de degradar uma grande quantidade de macromoléculas presentes não só na MEC, mas também na superfície celular. Em relação à sua estrutura geral, as MMPs possuem três domínios: o pró-peptídeo, o domínio catalítico, e o domínio C-terminal hemopexina (o qual está ligado ao domínio catalítico) (KESSENBROCK; PLAKS; WERB, 2010; OVERALL; BLOBEL, 2007).

As MMPs são inicialmente expressas em estado enzimaticamente inativo devido à interação de um resíduo de cisteína do pró-domínio com um íon zinco do 
domínio catalítico. Apenas após o rompimento dessa interação, mediado por remoção proteolítica do pró-domínio ou modificação química do resíduo de cisteína, as MMPs tornam-se ativas (PAGE-MCCAW; EWALD; WERB, 2007; STERNLICHT; WERB, 2001). As MMPs podem ser dividas simplificadamente em duas subclasses: MMPs solúveis e MMPs ancoradas à membrana (MT-MMP, do inglês "membranetype matrix metalloproteases") (PAGE-MCCAW; EWALD; WERB, 2007; ROWE; WEISS, 2009).

No desenvolvimento tumoral prostático, há uma expressão desequilibrada de MMPs. A elevada atividade de MMPs promove a progressão do câncer de próstata não só por facilitar a metástase, mas também por modificações nas vias de proliferação, apoptose e angiogênese. Geralmente, as MMPs estão mais ativas em canceres de estágio avançado. Análises biomoleculares e teciduais de tumores de próstata mostraram um aumento na expressão da MMPs, em especial das MMPs -2 , -7, -9 e -14 (LITTLEPAGE et al., 2010).

Atualmente, acredita-se que as MT-MMPs, em especial a MT1-MMP (MMP14), assumem um importante papel nos processos que envolvem a proteólise da lâmina basal e saída da célula tumora de seu sítio primário para tecidos adjacentes. Dos seis tipos de MT-MMPs que foram identificados, a MT1-MMP foi a mais estudada em câncer de próstata. A MT1-MMP possui aspectos estruturais similares a outras MMPs mas difere por estar ancorado à membrana plasmática da célula por um domínio transmembranar, expondo o seu domínio catalítico sobre a superfície celular (LI et al., 2008). MT1-MMP tem um amplo repertório de substratos de MEC, incluindo colágeno, laminina, fibronectina, desempenhando assim um papel importante na degradação da matriz extracelular em facilitar a migração celular e invasão (CHUN et al., 2004; SOUNNI et al., 2002).

As células do câncer de próstata interagem fortemente com a matriz extracelular e dependem de mecanismos de adesão com essa estrutura para seu crescimento. Estudos demonstram que mudanças na expressão de colágeno IV e laminina podem contribuir para o crescimento tumoral prostático (STEWART; COOPER; SIKES, 2004).

Em nosso laboratório, estudamos o papel da laminina no comportamento biológico de tumores (CAPUANO; JAEGER, 2004; FREITAS; JAEGER, 2002; FREITAS et al., 2004; FREITAS et al., 2007; GAMA-DE-SOUZA et al., 2008; SIQUEIRA et al., 2010; NASCIMENTO, 2011; SANTOS, 2011; SIQUEIRA, 2014). 


\subsection{Laminina}

A laminina é a glicoproteína mais abundante na membrana basal e exerce tanto atividades estruturais quanto biológicas (MARTIN; TIMPL, 1987; SASAKI; FASSLER; HOHENESTER, 2004). Essa molécula foi identificada em 1979 por Timpl e colabores, depois de ser isolada e purificada a partir de uma neoplasia de camundongo dotada de grande quantidade de membrana basal, o tumor EngelbrethHolm-Swarm (EHS) (TIMPL et al., 1979). A laminina é uma importante molécula para a organização da lâmina basal. Já foi demonstrado que camundongos que não expressam esta glicoproteína morrem logo após implantação do embrião, enquanto que na ausência de moléculas como perlecan, colágeno IV ou nidogênio, esta etapa ocorre normalmente (SASAKI; FASSLER; HOHENESTER, 2004)

A laminina é uma proteína heterotrimérica composta por três cadeias $(\alpha, \beta, \gamma)$ que se organizam formando uma estrutura cruciforme. Essa disposição dá origem a três braços curtos, e a um braço longo formado pelo entrelaçamento de porções de cada uma das três cadeias. Através de fotomicrografias eletrônicas, observou-se que a laminina possui domínios globulares (MARTIN; TIMPL, 1987; MINER; YURCHENCO, 2004b).

Atualmente, a família das lamininas é constituída por 16 isoformas, mas provavelmente existem outras que ainda não foram isoladas (MALINDA; KLEINMAN, 1996; MINER; YURCHENCO, 2004b; PONCE; NOMIZU; KLEINMAN, 2001). As isoformas de laminina são sintetizadas por praticamente todas as células epiteliais, além de células musculares lisas, de tecido ósseo, de músculo cardíaco, nervosas, endoteliais e de medula óssea. Após a síntese, esta molécula se deposita principalmente, mas não exclusivamente, na membrana basal (BOSMAN; STAMENKOVIC, 2003).

A laminina contribui fortemente para a organização molecular final da membrana basal, e neste contexto interage com ela mesma e com colágeno IV, nidogênio e proteoglicanas (BOSMAN; STAMENKOVIC, 2003; COLOGNATO; YURCHENCO, 2000; MALINDA; KLEINMAN, 1996; MARTIN; TIMPL, 1987). Além disso, parece estar relacionada com o início da formação da matriz da membrana basal, já que é a primeira molécula a ser sintetizada durante o desenvolvimento embrionário (COLOGNATO; YURCHENCO, 2000; MALINDA; KLEINMAN, 1996). A importância da laminina é ainda reforçada pelo fato de sua ausência impedir a 
formação da membrana basal (YURCHENCO; AMENTA; PATTON, 2004; YURCHENCO; WADSWORTH, 2004a).

Além de funções estruturais, a laminina possui diversas atividades biológicas, que incluem adesão celular, espraiamento, migração, proliferação, metástase de tumores e secreção de proteases (BOSMAN; STAMENKOVIC, 2003; MALINDA; KLEINMAN, 1996; MARTIN; TIMPL, 1987; PONCE; NOMIZU; KLEINMAN, 2001). Já foi observado que células cultivadas sobre laminina formam mais tumores in vivo do que células não aderentes ou células aderentes à fibronectina (TERRANOVA et al., 1984). Ainda, células tumorais co-injetadas com laminina em ratos atímicos promovem aumento da formação de colônias metastáticas pulmonares nesses animais (IWAMOTO et al., 1987).

A laminina, assim como outras moléculas da matriz extracelular, é capaz de regular atividades celulares e pode fornecer instruções que aparecem de acordo com as necessidades celulares (SCHENK; QUARANTA, 2003). Dissecção bioquímica da laminina relatou que algumas de suas funções são específicas a porções dessa glicoproteína, demonstrando que diferentes partes da laminina exercem efeitos diferentes nas células (FAISAL KHAN et al., 2002). Estudos evidenciaram que pequenas sequências de aminoácidos derivadas da laminina são capazes de estimular funções biológicas. Essas sequencias são conhecidas como peptídeos bioativos e algumas das funções que exercem não são as mesmas da proteína íntegra (HANDSLEY; EDWARDS, 2005; SCHENK; QUARANTA, 2003).

Por tal motivo, os efeitos da laminina não podem ser relacionados apenas a sua molécula como um todo, uma vez que possuem escondida em sua estutrura, diversos sítios ativos. Esses sítios podem não estar expostos na superfície da molécula na sua forma intacta, sendo denominados matricriptinas ou sítios matricrípticos (SCHENK; QUARANTA, 2003).

Os mecanismos que regulam a exposição de sítios matricrípticos representam uma etapa relevante no controle dos vários eventos biológicos promovidos pela MEC. Pelo menos cinco mecanismos vinculados à geração desses sítios já foram descritos, e todos envolvem modificação estrutural e conformacional de moléculas da matriz. 1) degradação enzimática por ação proteolítica; 2) ligação heterotípica (adsorção) a outras moléculas, levando a mudança conformacional; multimerização (organização de moléculas em arranjo), (4) forças mecânicas 
mediadas por células e (5) denaturação (DAVIS et al., 2000; SCHENK; QUARANTA, 2003) .

Estudos demonstram que em cânceres de próstata de alta agressividade, há uma acentuada diminuição na expressão de laminina, o que indica o rompimento da membrana basal adjacente às células tumorais. Este evento pode fazer com que ocorra a exposição desses sítios matricrípticos, podendo de alguma forma auxiliar no crescimento tumoral (BRAR et al., 2003).

\subsubsection{Laminina-111 e o peptídeo bioativo derivado}

Como o peptídeo que estudamos neste trabalho é derivado da cadeia $\gamma 1$ da laminina-111, faremos uma breve revisão sobre esta molécula.

Dentre todas as isoformas da laminina, a laminina-111 (antiga laminina-1, 900 kDa) formada pelas cadeias $\alpha 1$ (400 kDa), $\beta 1$ (200 kDa) e $\gamma 1$ (200 kDa) é a mais estudada e foi a primeira a ser identificada, estruturalmente analisada e sequenciada (AUMAILLEY; SMYTH, 1998; COLOGNATO; YURCHENCO, 2000; EKBLOM et al., 1998a; TIMPL; BROWN, 1994).

O modelo estrutural proposto para a laminina-111 foi baseado na correlação entre análise química da proteína, observações em microscopia eletrônica e estudo de fragmentos proteolíticos purificados. Nesse modelo, as cadeias $\alpha 1, \beta 1$ e $\gamma 1$ dispõem-se como uma bobina enrolada sobre si mesma. As cadeias $\alpha 1$ possuem três domínios globulares em sua porção amino-termina, separados por repetições do tipo EGF (fator de crescimento epidermal). Na porção carbóxi-terminal existe um domínio tipo bobina e um grande domínio globular contendo 5 glóbulos. As cadeias $\beta 1$ e $\gamma 1$ são menores em relação à $\alpha$, contendo apenas dois domínios globulares e duas repetições tipo EGF na porção amino-terminal. Pontes dissulfeto unem as cadeias próximas ao domínio carbóxi-terminal, enquanto a porção amino-terminal permanece livre (AUMAILLEY et al., 2005; MINER; YURCHENCO, 2004b). As três cadeias que formam a laminina-111 apresentam três braços curtos, sendo que um possui $48 \mathrm{~nm}$ de comprimento e dois possuem $34 \mathrm{~nm}$. Já braço longo posui $77 \mathrm{~nm}$ de comprimento (AUMAILLEY; SMYTH, 1998) 
A cadeia $\gamma 1$ está presente na maioria das isoformas da laminina, exceto na laminina 332 (antiga laminina 5) (BURGESON et al., 1994; COLOGNATO; YURCHENCO, 2000; EKBLOM et al., 1998a; NOMIZU et al., 1997; PONCE; KLEINMAN, 2003). Essa cadeia apresenta ligação com alta afinidade ao nidogênio, que está presente em todas as lâminas basais. A interação ocorre através de domínios EGF-“like" localizados no braço curto da cadeia e parece ser particularmente interessante, uma vez que anticorpos que bloqueiam a ligação mostraram inibir de maneira significativa a morfogênese de pulmão, glândula salivar e rim (EKBLOM et al., 1998b; EKBLOM, 1996; EKBLOM; TIMPL, 1996; NOMIZU et al., 1997).

Além de seu papel no desenvolvimento, a laminina-111 também é uma molécula adesiva para a maioria dos tipos celulares e ainda promove espraiamento, proliferação, crescimento de neuritos, metástase tumoral, angiogênese, secreção de protease e colagenase IV (FRIDMAN et al., 1990; KANEMOTO et al., 1990; KURATOMI et al., 2002; MARTIN; TIMPL, 1987; PONCE; KLEINMAN, 2003; PONCE; NOMIZU; KLEINMAN, 2001; POWELL; KLEINMAN, 1997). Células mioepiteliais derivadas de tecido glandular de mama normal atuam mantendo a correta polaridade celular através de sua habilidade em sintetizar laminina-111 (GUDJONSSON et al., 2002). Células derivadas de carcinomas parecem ser capazes de sintetizar, depositar e utilizar diferentes isoformas de laminina, como a 111 (PATARROYO; TRYGGVASON; VIRTANEN, 2002; ZIOBER; FALLS; ZIOBER, 2006). Trabalho verificou que células derivadas de melanoma eram capazes de produzir e sintetizar laminina-111 e que ainda essa molécula é capaz de promover migração dessas células (OIKAWA et al., 2011).

As várias atividades biológicas estimuladas pela laminina, tanto em células normais quanto neoplásicas, despertaram o interesse em estudar os diferentes sítios ativos da molécula. Para realizar esses estudos, foram utilizados clones de cadeias de laminina, sequências de peptídeos correspondentes a vários domínios estruturais (fragmentos proteolíticos e peptídeos sintéticos) e anticorpos.

Para pesquisar sequências biologicamente ativas na molécula de laminina111, foram realizadas varreduras sistemáticas de sequências, com posterior síntese de 560 peptídeos das três cadeias da laminina-111 $(\alpha 1, \beta 1, \gamma 1)$, sendo 2008 peptídeos da cadeia $\alpha 1,187$ da cadeia $\beta 1$ e 165 da cadeia $\gamma 1$. Depois de 
sintetizados, os peptídeos foram testados quanto a sua capacidade de adesão. Dentre os 560 peptídeos, apenas 51 foram identificados como sequências adesivas, sendo 25 da cadeia $\alpha 1,14$ da cadeia $\beta 1$ e 12 da cadeia $\gamma 1$ (NOMIZU et al., 2000; NOMIZU et al., 1997; NOMIZU et al., 2001).

Nomizu et al. (1997) realizaram varreduras sistemáticas de sequências e ensaios de adesão e revelaram 20 sequências ativas dessa cadeia. Dentre essas sequências, foram encontrados quatro peptídeos com forte atividade adesiva e avaliados quanto à capacidade de estimular atividades biológicas. O peptídeo C16 (KAFDITYVRLKF), presente no primeiro domínio globular da cadeia $\gamma 1$, foi identificado como uma dessas sequências ativas e mostrou ter forte atividade adesiva em células de fibrossarcoma (HT1080) e melanoma (B16-F10) (NOMIZU et al., 1997).

Trabalho realizado por Kuratomi et al. (2002) mostrou que o peptídeo C16 induziu um aumento significativo de metástase pulmonar de células de melanoma (B16-F10) (KURATOMI et al., 2002). Além disso, o peptídeo estimulou migração e secreção de MMP9 nessas células. Embora os mecanismos envolvidos nesses processos não tenham sido descritos pelos autores, eles acreditam que C16 desempenhe papel em várias etapas da metástase, como adesão, migração e invasão.

O peptídeo C16 utilizado em trabalhos do laboratório são derivados da laminina-111, dado devida ênfase na revisão (GAMA-DE-SOUZA et al., 2008). Porém, não só esta laminina, mas também outras, como a laminina 511 (antiga laminina-10), possuem a cadeia $\gamma 1$. Os tumores de próstata de alta agressividade apresentam uma proeminente expressão da laminina 10 (BRAR et al., 2003), e através de sua proteólise, seria sugestivo dar origem a peptídeos bioativos como o C16. Dados de nosso grupo mostram que o peptídeo C16 migração, invasão e secreção de protease em células de carcinoma adenóide cístico e carcinoma epidermódie (NASCIMENTO et al., 2011; SIQUEIRA, 2014). Neste trabalho, buscamos elucidar o papel de C16 na biologia tumoral do tumor de próstata, não visto antes na literatura 


\section{$2.4 \quad$ Invadopódios}

As etapas da metástase tumoral compreendem a separação das células neoplásicas do sítio primário de desenvolvimento, passagem pela matriz extracelular, invasão ao tecidos adjacentes, rompimento da parede de vasos e entrada na corrente sanguinea. Distintos programas moleculares são responsáveis pela regulação da adesão e migração, sendo estes processos dependentes da dinâmica do citoesqueleto para a formação de invadopódios (KAHN; COLLAZO; KYPRIANOU, 2014; SIBONY-BENYAMINI; GIL-HENN, 2012). Os invadopódios podem ser definidos como protrusões ventrais de membrana que se estendem verticalmente para a MEC (COURTNEIDGE, 2012). Essas protrusões são ricas em filamentos de actina e proteínas associadas, como proteínas de adesão, proteases de matriz e moléculas sinalizadoras que regulam o citoesqueleto de actina e a remodelação da membrana (BOWDEN et al., 1999; BUCCIONE; ORTH; MCNIVEN, 2004; CHEN, 1989).

O início dos estudos para descoberta dos invadopódios deu-se na década de 80, quando se observou uma reestruturação das proteínas do citoesqueleto em fibroblastos transformados com o vírus do Sarcoma de Rous (DAVID-PFEUTY; SINGER, 1980). Foi demonstrada a formação de estruturas que possuíam pontos de ligação com a MEC, estavam ventralmente localizadas, continham actina e domínios protéicos de tirosina fosforiladas. Estas estruturas foram descritas inicialmente por Marchisio e denominadas pés celulares e, posteriormente, podossomos (CHEN, 1989; MARCHISIO et al.,1984; TARONE et al., 1985). Foi observado que não só as células transformadas, mas também outros grupos celulares possuíam podossomos, como os osteoclastos (ZAMBONIN-ZALLONE et al., 1988). O grupo de Chen demonstrou que estes podossomos eram dotadas de capacidade proteolítica, degradando o local de adesão à MEC. Descreveram também estruturas similares com habilidade de degradação da MEC linhagens tumorais, sendo chamadas de invadopódios para enfatizar sua natureza protrusiva (CHEN, 1989).

Sendo assim, utilizou-se por um tempo as nomenclaturas podossomos e invadopódios para caracterizar a mesma estrutura. Apesar das similaridades, diferenças morfológicas e moleculares foram observadas. Atualmente, o termo podossomo é adotado para células normais, onde estas estruturas desempenham um importante papel para motilidade como monócitos, macrófagos, células 
dendríticas e osteoclastos. Já os invadopódios são encontrados em células tumorais, como as células do câncer de próstata (CHEN et al., 1985; DESAI; MA; CHELLAIAH, 2008; GIMONA et al., 2008; MARCHISIO et al., 1984). Estruturalmente, os podossomos são relativamente menores, apresentando $1 \mu \mathrm{m}$ de diâmetro e comprimento de $0.4 \mu \mathrm{m}$. Utilizam-se primariamente da protease MT1-MMP para proteólise pericelular. Já os invadopódios são maiores e podem medir até $8 \mu \mathrm{m}$ de diâmetro, atingem um comprimento maior que $4 \mu \mathrm{m}$ e utilizam-se, além de MT1MMP, de outras proteases como MMP2, MMP9 e ADAMs (BUCCIONE; CALDIERI; AYALA, 2009; CLARK; WEAVER, 2008; GIMONA et al., 2008; STYLLI; KAYE; LOCK, 2008).

Estudos in vitro são utilizados para melhor estudo da morfologia, localização e atividade dos podossomos e dos invadopódios. Para isso, células são marcadas com faloidina, que se liga a actina, e com anticorpos contra proteínas chaves para a formação dos invadopódios e reestruturação do citoesqueleto como a ARP2/3, que promove a nucleação da actina, e cortactina. Como outras estruturas celulares podem também ser evidenciadas pelo mesmo método, é importante determinar que esta marcação esteja localizada ventralmente na célula para melhor caracterizar os invadopódios (ABRAM et al., 2003; DIAZ et al., 2009; OIKAWA; ITOH; TAKENAWA, 2008). Outro método conhecido e largamente utilizado é o ensaio de degradação da matriz fluorescente (ARTYM et al., 2006; CHEN et al., 1985; YAMAGUCHI; PIXLEY; CONDEELIS, 2006). Este experimento é importante para detectar os estágios de formação dos invadopódios. Nesse ensaio, células são crescidas sobre lamínulas que contém uma gelatina fluorescente conjugadas a fluorocromos. A atividade de degradação dos invadopódios é verificada por regiões com ausência de fluorescência, ou seja, áreas escuras no substrato fluorescente que são detectadas por microscopia de fluorescência ou microscopia confocal (ARTYM et al., 2006; BOWDEN et al., 1999; CHEN et al., 1985).

Sabe-se que uma grande variedade de proteínas está associada aos invadopódios, incluindo proteínas de adesão, transdução de sinal, regulação de actina, proteólise da MEC e dinâmica da membrana (BUCCIONE; ORTH; MCNIVEN, 2004). Podem ser dividas em: 1) Arp2/3, N-WASp, Cdc42, Nkc, cofilina, cortactina, dinamina sendo reguladores da polimerização da actina, considerados como o motor para o funcionamento do invadopódios. 2) Integrinas e proteínas de adesão que são responsáveis por modular a interação dos invadopódios com a MEC. 3) Tirosina 
quinases e GTPases Ras que são do grupo de proteínas sinalizadoras que regulam o citoesqueleto de actina e a remodelação da membrana. 4) MT1-MMP, MMP-2 e MMP-9 que são proteases que modulam a degradação da MEC em sítios funcionais dos invadopódios (ARTYM et al., 2006; CLARK; WEAVER, 2008; MONSKY; CHEN, 1993).

Estudos mostram que vários estímulos, como TGF $\beta$ e EGF, induzem à formação de invadopódios por ativar vias de sinalização relacionadas à fosforilação e ativação de diversas proteínas através de integrinas (DESTAING et al., 2008; THOMAS; BRUGGE, 1997). As quinases da família Src possuem papel importante na formação dos invadopódios. Atividade elevada desta tirosina parece ser essencial para a organização dos invadopódios tanto em células normais quanto transformadas (KELLEY et al., 2010; TARONE et al., 1985). A fosforilação de resíduos de tirosina exerce um papel fundamental para a formação dos invadopódios. Após integrinas serem ativadas, Src é fosforilado e é capaz de ativar/fosforilar outros substratos, como o Tks5. Tks5 é uma proteína adaptadora que contém um domínio N-terminal Phox (PX), seguido de 5 domínios SH3 sendo seu recrutamento facilitado pela ligação de seu domínio PX com fosfatidilinositol-3-4bifosfato (Ptdlns $\left.(3,4) \mathrm{P}_{2}\right)$ ancorado no membrana. Em condições fisiológicas, encontram difuso pelo citoplasma, já em condições patológicas ancora-se a membrana e colocaliza-se com a cortactina (DESAI; MA; CHELLAIAH, 2008; FEKETE et al., 2013; OSER et al., 2009; YAMAGUCHI; OIKAWA, 2010).

No final da década de 90, o grupo de Lock identificou a proteína Tks5 em células NIH-3T3 transformadas pelo vírus de Sarcoma de Rous. Verificaram que esta proteína era um substrato de Src e estava localizada nos podossomos dos fibroblastos (LOCK et al., 1998). Experimentos subsequentes avaliaram o papel de Tks5. Uma redução em sua expressão mostrou que a proteína era necessária para a formação dos podossomos, degradação da MEC e invasão através do Matrigel (SEALS et al., 2005). Tks5 mostrou-se essencial também na formação dos invadopódios em células tumorais, sendo encontrado em várias linhagens neoplásicas, como na próstata. Experimentos em vitro demonstram que o silenciamento da proteína diminuiu a capacidade invasiva de células de câncer de mama e não há a formação de invadopódios (BLOUW et al., 2008; SEALS et al., 2005). Atualmente é investigado se Tks5 tem função no processamento proteolítico no microambiente tumoral. Tks5 não possui atividade catalítica intrínseca e 
experimentos sugerem que o quinto domínio $\mathrm{SH} 3$ de Tks5 liga-se às metaloproteases transmembrana ADAMs 12, 15 e 19 para realizar a proteólise pericelular (ABRAM et al., 2003).

Outro importante substrato de Src é Tks4. Sua descoberta se deu através dos estudos dos genes de Tks5, onde verificou-se uma sequência similar a Tks5. Tks4 é uma proteína adaptadora que possui um domínio N-terminal Phox (PX), com quatro domínios SH3. A diferença apresentada entre as duas proteínas é o sítio de fosforilação por Src e seus papéis temporais na formação dos invadopódios. Tks4 também tem papel importante na formação dos invadopódios. Estudos mostram que a inibição de Tks4 resultaram numa falha formação dos invadopódios, sugerindo que a proteína tem relevância na dinâmica dos invadopódios, porém atue de forma um pouco tardia. A proteólise pericelular foi inibida, o que indica que Tks4 seja responsável pelo recrutamento de proteases, principalmente da MT1-MMP (BUSCHMAN et al., 2009; GIANNI et al., 2009). MT1-MMP tem papel crucial nos processos de invasão celular de linhagens com fenótipo invasivo, sendo acumulada na região dos invadopódios (OHUCHI et al., 1997; SABEH et al., 2004). O diagrama a seguir mostra os domínios moleculares de Tks4 e 5.

\section{Tks4}

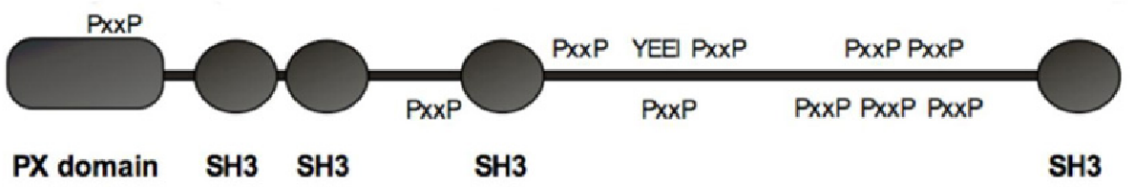

Tks5

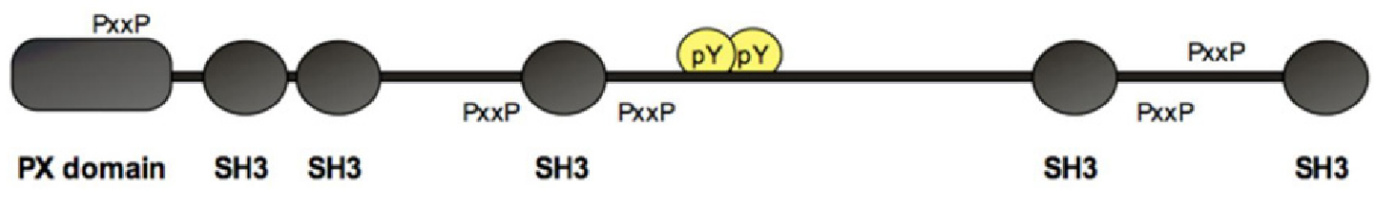

Diagrama 2.4.1. Esquema ilustra a estrutura de Tks4 e Tks5 com seus domínios $P X$ e SH3. PxxP representa os motivos prolina ao longo da molécula; pY e YEEl são os locais de fosforilação mediado por Src (COURTNEIDGE et al., 2005). 
A localização de Tks5 na membrana é essencial no remodelamento do citoesqueleto para a formação dos invadopódios. Seu domínio N-terminal é capaz de se ligar a proteínas como N-WASp, cortactina, Nkc e Grb2 que estão ligadas com a reestruturação da actina (BURGER et al., 2014; COURTNEIDGE, 2012). Já o recrutamento Tks4 para a região do invadopódio é essencial para a estabilização de MT1-MMP (MURPHY; COURTNEIDGE, 2011).

A formação dos invadopódios é dividida em três etapas: iniciação, montagem e maturação. No início do processo, há a interação com receptores de membrana tipo integrina que enviam sinais do microambiente para a modificação estrutural do citoesqueleto. Os invadopódios iniciam próximos às adesões focais (FAK). Estes estímulos promovem uma autofosforilação de FAK, que são fosforiladas no resíduo Tyr 397. FAK possui um domínio com grande afinidade por Src, e desencadeia sua ativação. A ativação de Src permite que seus substratos Tks4 e Tks5 sejam fosforilados e assim, p-Tks5 liga-se a Ptdlns $(3,4) \mathrm{P}_{2}$ através do domínio PX, com posterior ancoragem na membrana. $\mathrm{Na}$ fase de montagem, tem-se a elongação da estrutura do invadopódios com o recrutamento e ativação de reguladores de actina pela $\mathrm{p}$-Tks5, como Arp2/3, N-WASp e de cortactina. Atualmente, não é completamente conhecido o mecanismo por qual Tks5 e cortactina unem-se para a montagem dos invadopódios. Tks5 pode se ligar diretamente a proteínas chaves de regulação da actina, como Nck1, Nck2, N-WASp e Grb2, enquanto a cortactina associa-se a outras proteínas regulatórias como N-WASp e Arp2/3, formando complexos com a GTPase Cdc42. Sugere-se que estas proteínas regulatórias serviram como pontes de ligação entre Tks5 e cortactina (CRIMALDI; COURTNEIDGE; GIMONA, 2009; SHARMA et al., 2013). No processo de maturação há a atividade de degradação da MEC pelas metaloproteinases, principalmente MT1-MMP, tendo Tks4 papel essencial em sua estabilização (CLARK; WEAVER, 2008; COURTNEIDGE et al., 2005; MURPHY; COURTNEIDGE, 2011). O diagrama a seguir mostra as diferentes fases de formação dos invadopódios. 

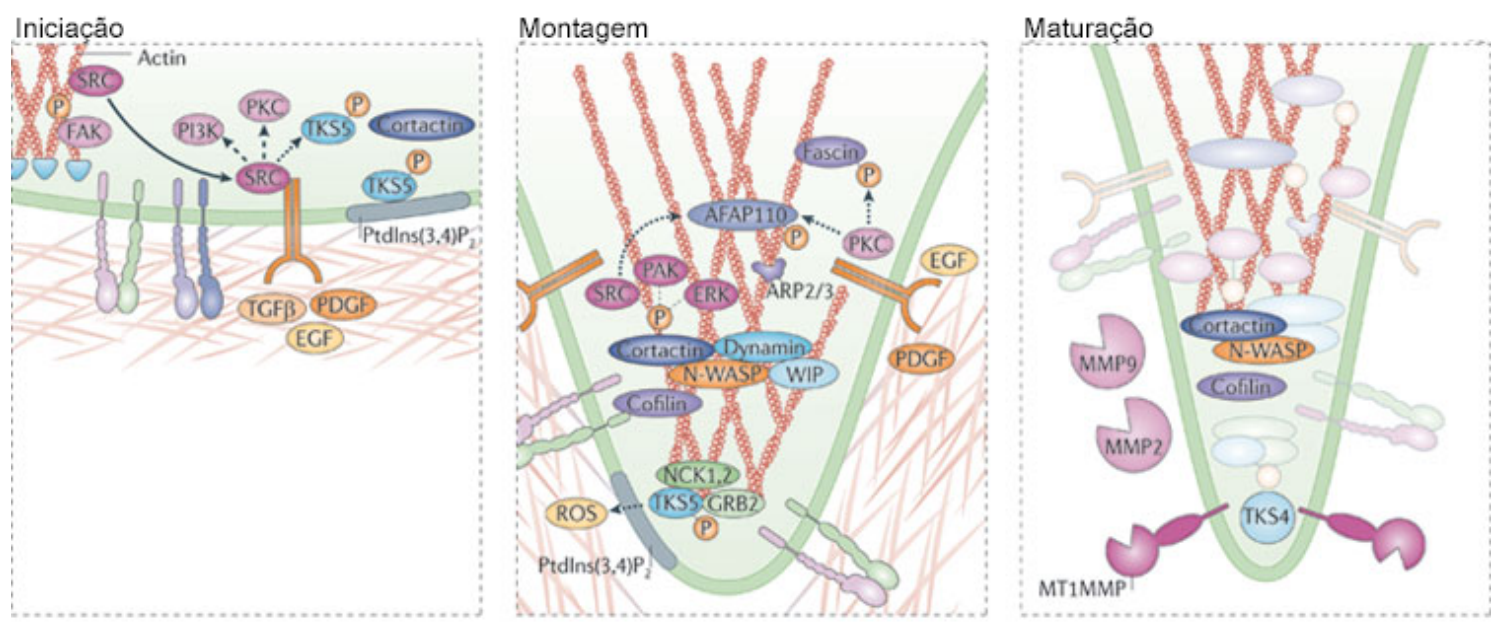

Diagrama 2.4.2 Representação das etapas de formação dos invadopódios e suas proteínas envolvidas (MURPHY; COURTNEIDGE, 2011).

Há vários outros fatores que podem contribuir para a característica invasiva as células tumorais, como as espécies reativas de oxigênio (ROS). As espécies reativas de oxigênio (peróxidos e superóxidos), são produzidas nos processos metabólicos de células normais, como na fosforilação oxidativa das mitocôndrias ou pela ativação de membros da família NAPH oxidase (NOX), desempenhando um importante papel na manutenção da homeostasia celular. Porém, um aumento em sua produção proveniente do desequilíbrio celular como infecção, envelhecimento e mutações no DNA mitocondrial, acarreta em danos teciduais e modificações no DNA, como rearranjo de sequências de bases. E não apenas estes eventos são ocasionadas pelo desequilíbrio da produção de ROS. Atualmente, pesquisas mostram que ROS também estão envolvidas na mudança de vias de sinalização de processos celulares associados com transformação neoplásica e respostas proliferativas e apoptóticas (LAMBETH, 2007; NAKA et al., 2008). O estresse oxidativo foi relacionado com um aumento no risco de desenvolvimento do tumor de próstata. Estudos indicam que há uma elevada produção de ROS no epitélio prostático de pacientes acometidos pela neoplasia, quando comparados a tecidos de pacientes sadios (KUMAR et al., 2008).

A ativação de NADPH oxidase é importante para a geração de espécies reativas de oxigênio. As nicotinamida adenina dinucleotídeo fosfato (NADPH) oxidases constituem um grupo de enzimas transmembrana que catalisam a transferência de elétrons através da membrana celular e estão presentes 
principalmente nos fagócitos, mas também em células não fagocitárias como tireoide, colón e próstata (BABIOR, 1999; BEDARD; KRAUSE, 2007). São compostas por subunidades: duas proteínas transmembrana: p22phox e gp91phox/NOX2; as outras subunidades constituem-se de três proteínas citosólicas: p47phox, p67phox, p40phox e uma GTPase (Rac1 ou Rac2) (EL-BENNA et al., 2008; GROEMPING \& RITTINGER, 2010). A ativação celular por estímulos fisiológicos como bactérias e fungos, moléculas indutoras de quimiotaxia (anticorpos) ou agentes não fisiológicos, levam à fosforilação da proteína citoplasmática p47phox, levando todo o complexo citoplasmático a migrar para a membrana e se associar ao complexo NADPH oxidase. A agregação ao complexo NADPH oxidase permite o início da transferência eletrônica para o oxigênio molecular, gerando ânion superóxido e em seguida, espécies reativas de oxigênio (ROS) (BABIOR, 1999).

Estudos sugerem que Tks5 tenha papel relevante na produção de ROS. Sabe-se que Tks5 possui um domínio PX seguido de 5 sequências SH3, assim como p47phox. Tks5 fosforilada pode então assumir o papel de p47phox, interagir e ativar NOX para a produção de ROS, promovendo o aumento da degradação da MEC e migração das células tumorais (BRIEGER et al., 2012; COURTNEIDGE, 2012). Essa ativação, além de desencadear um desequilíbrio metabólico citado anteriormente, ROS podem também estimular a formação de invadopódios, secreção de metaloproteinases, ou até mesmo dirigir sinais para ativação de Src (D'AUTREAUX; TOLEDANO, 2007; WEAVER, 2009).

Os invadopódios são capazes de promover a proteólise de constituintes da lâmina basal, como as lamininas (KELLY et al., 1994). Dados de nosso laboratório mostram que o peptídeo C16 estimula a atividade de invadopódios em linhagem de carcinoma adenóide cístico e de carcinoma epidermóide oral (NASCIMENTO et al., 2011; SIQUEIRA, 2014). No entanto, os efeitos dos peptídeos da laminina na dinâmica de formação de invadopódios em células de tumor de próstata ainda não foram observados. 


\section{PROPOSIÇÃO}

Analisamos o papel do peptídeo bioativo C16, derivado da cadeia $\gamma 1$ da laminina, nos processos de migração, invasão e atividade de invadopódios em linhagens celulares derivadas de carcinoma prostático.

1) Efeito de C16 na atividade de migração, invasão e atividade dos invadopódios em células de carcinoma prostático (DU145);

2) Análise dos mecanismos envolvidos aos efeitos biológicos de C16, envolvendo o estudo de moléculas chaves relacionadas à formação dos invadopódios; bem como possível via de sinalização modulada pelo peptídeo.

3) Verificar se C16 induz a formação de espécies reativas de oxigênio 


\section{MATERIAL E MÉTODOS}

Esse trabalho não envolveu manipulação direta nem de seres humanos e nem de animais, e foi aprovado pelo Comitê de Ética e Pesquisa (CEP-ICB), parecer $\mathrm{n}^{\circ} 536 / 12$, de 08 de agosto de 2012.

\subsection{Peptídeos}

Peptídeo C16, derivado da cadeia $\gamma 1$ da laminina, foi sintetizado pela empresa EZ Biolab (Westfield, IN, USA), possuindo grau de pureza de 98\% (RP-HPLC) e massa molecular confirmada por espectrometria de massa. Utilizamos também um peptídeo contendo os mesmos aminoácidos de C16 com sequência embaralhada (peptídeo "scrambled" - C16SX), que serviu como controle nos experimentos.

As sequências de aminoácidos dos peptídeos C16 e C16SX, bem como a cadeia da laminina à qual pertencem estão listados na tabela abaixo:

Tabela 4.1: Sequência de aminoácidos dos peptídeos C16 e C16SX.

\begin{tabular}{c|c|c}
\hline Peptídeo & Sequência & Sequência "scrambled" \\
\hline \hline C16 & KAFDITYVRLKF & FKLRVYTIDFAK \\
\hline
\end{tabular}

\subsection{Linhagem celular}

Linhagem celular derivada de sítio metastático cerebral de células de carcinoma de próstata (DU145) foi gentilmente cedida pelo Prof. Hernandes Faustino de Carvalho (Instituto de Biologia - Universidade Estadual de Campinas Unicamp, Campinas, SP). Células foram cultivada em meio DMEM/F-12 (Sigma Chemical Corp., St Luis, MO, USA) suplementado com $10 \%$ de soro fetal bovino (Life Technologies, Carlsbad, CA, USA). Células foram mantidas em frascos de 25 $\mathrm{cm}^{2}$ a $37^{\circ} \mathrm{C}$, em atmosfera úmida contendo $5 \%$ de $\mathrm{CO} 2$. 


\subsection{Ensaio de Migração}

Com o intuito de analisar se o peptídeo da laminina estimula migração em células de tumor de próstata DU145, foi utilizado um sistema de câmaras de quimiotaxia bipartites de 10 poços (Neuro Probe Inc. Gaithersburg, MD, USA), separadas por membrana porosa de policarbonato (diâmetro dos poros $=8 \mu \mathrm{m}$ ). Os poços da câmara inferior foram preenchidos com peptídeo C16 diluídos em meio contendo $0,5 \%$ de SBF $(20-500 \mu \mathrm{g} / \mathrm{ml})$. Células DU145 foram ressuspendidas em meio sem soro (10 5 poço), colocadas na porção superior da câmara sobre membrana porosa. Como controles, utilizamos peptídeo "scrambled" diluído em meio com $0,5 \%$ de soro $(20-500 \mu \mathrm{g} / \mathrm{ml})$. Controles não peptídicos também foram utilizados. Dessa forma, poços da câmara inferior foram preenchidos por meio contendo $0,5 \%$ de SBF (controle negativo) ou por meio suplementado com $10 \%$ de SBF (controle positivo).

A câmara foi então incubada por 16 horas a $37^{\circ} \mathrm{C}$ em estufa de $\mathrm{CO}_{2}$. Caso o peptídeo estimule a migração, as células passariam da câmara superior para a inferior. A membrana foi então removida da câmara e sua porção superior, sobre a qual as células foram plaqueadas, foi delicadamente raspada para remoção das células que não migraram. Assim, restaram somente as células da face inferior da membrana. Essas células foram fixadas em paraformaldeído $4 \%$ e coradas com violeta cristal.

O número de células em cada poço foi observado por meio da aquisição de imagens utilizando câmera digital acoplada ao microscópio, e contado em pelo menos 7 campos para cada grupo. Ensaios foram realizados em triplicata.

\subsection{Ensaio de Invasão}

Para avaliar se o peptídeo induz fenótipo invasivo das células DU145, foi utilizado o mesmo sistema de câmaras de quimiotaxia empregado nos ensaios de migração (NeuroProbe), com membrana porosa de policarbonato coberta por membrana basal reconstituída (Matrigel, Trevigen Inc, Gaithesburg, MD, USA - 14 $\mu \mathrm{g} / \mathrm{ml})$. Células DU145 ressuspendidas em meio sem soro $\left(1.5 \times 10^{5} /\right.$ poço $)$ foram colocadas na porção superior da câmara. Os poços da câmara inferior foram 
preenchidos com peptídeo C16 diluído em meio contendo 0,5\% de SBF (20-500 $\mu \mathrm{g} / \mathrm{ml}$ ). Como controles, utilizamos peptídeo "scrambled" diluído em meio contendo $0,5 \%$ de SBF $(20-500 \mu \mathrm{g} / \mathrm{ml}$ ). Meio contendo $0,5 \%$ (controle negativo) ou $10 \%$ (controle positivo) de SBF foram utilizados como controles não peptídicos.

A câmara foi incubada por 40 horas a $37{ }^{\circ} \mathrm{C}$ em estufa de $\mathrm{CO}_{2}$ para que ocorresse digestão do Matrigel e invasão das células da câmara superior para a inferior. A membrana foi então removida da câmara e sua porção superior, sobre a qual as células foram plaqueadas, foi delicadamente raspada para remoção de restos de Matrigel e de células que não invadiram. Assim, restaram somente as células da face inferior da membrana. Os processos de limpeza da membrana, fixação, coloração e contagem das células que invadiram foram feitos usando-se o mesmo protocolo descrito para o ensaio de migração. Experimentos realizados em triplicata.

\subsection{Determinação de invadopódios em células DU145 tratadas pelo peptídeo C16 crescidas sobre substrato fluorescente}

\subsubsection{Preparo do Substrato Fluorescente}

Substrato fluorescente foi obtido comercialmente (gelatina-FITC, Invitrogen Life Technologies). Lamínulas de vidro $(18 \times 18 \mathrm{~mm})$ foram cobertas com gelatina fluorescente, seguindo protocolo de Artym (ARTYM et al., 2006). Em resumo, lamínulas foram incubadas com solução de poli-I-lisina (Sigma) por 20 minutos à temperatura ambiente, lavadas em PBS e fixadas em glutaraldeído 0,5\% por 15 minutos. Em seguida, foram lavadas com PBS e invertidas sobre mistura de 8 partes de gelatina $0,2 \%$ (Sigma) e 1 parte de gelatina fluorescente por 10 minutos à temperatura ambiente. Após lavagem em PBS, lamínulas contendo gelatina fluorescente foram incubadas com borohidreto de sódio (5 mg/ml, Sigma) por 15 minutos, para remoção de grupos reativos residuais presentes nos substratos

\subsubsection{Ensaio de Degradação em Substrato Fluorescente}

Para avaliar a capacidade do peptídeo C16 de estimular a atividade dos invadopódios, células DU145 $\left(2 \times 10^{4}-10^{5}\right)$ foram cultivadas sobre substrato de 
gelatina fluorescente (FITC) em meio de cultura contendo $0,5 \%$ de SBF e mantidas em estufa de $\mathrm{CO}_{2}$ a $37^{\circ} \mathrm{C}$. Após período de adesão inicial (1-3 horas), essas células foram tratadas pelo peptídeo C16 $(100 \mu \mathrm{g} / \mathrm{ml})$ diluído em meio com $0,5 \%$ de SBF. Células tratadas por peptídeo "scrambled" C16SX $(100 \mu \mathrm{g} / \mathrm{ml})$ diluído em meio com $0,5 \%$ de SBF serviram como controle. Para controles não peptídicos foram utilizados meio de cultura contendo $0,5 \%$ SBF (controle negativo) e meio contendo $10 \%$ SBF (controle positivo).

Após 16 horas mantidas em estufa de $\mathrm{CO}_{2}$ a $37^{\circ} \mathrm{C}$, amostras foram fixadas em paraformaldeído 4\% em PBS por 10 minutos, permeabilizadas com Triton X-100 $0,5 \%$ (Sigma) em PSB por 5 minutos e bloqueadas com soro de cabra $10 \%$ (Kirkegaard \& Perry Laboratories - KPL, Gaithersburg, MD, USA) por 1 hora. Em seguida, as amostras foram submetidas à marcação para actina utilizando rodaminafaloidina 568 (Invitrogen, Life Technologies - diluição 1:2000), com o intuito de delinear o contorno da célula e seus prolongamentos em direção ao substrato fluorescente. A montagem das lâminas foi realizada com ProLong Gold (Invitrogen Life Technologies).

\subsubsection{Microscopia e Análise das Imagens}

Amostras foram examinadas, em microscópio de fluorescência Axiophot (Carl Zeiss, Oberkochen, Germany), utilizando objetiva PlanApo 100x (Abertura numérica 1.4). Imagens das células e do substrato de gelatina foram adquiridas com o auxílio de câmera monocromática CCD digital, específica para amostras fluorescentes (CoolSNAP HQ2, Photometrics Inc, Tucson, AZ, USA). Para observar a extensão de invadopódios em direção ao substrato fluorescente, no mínimo 10 secções no eixo $Z$ por campo da amostra foram obtidas, utilizando um acessório piezoelétrico (PIFOC, Physik Instrumente, Germany) acoplado à objetiva. O microscópio e demais equipamentos foram controlados em estação gráfica com o software Metamorph Premier 7.6 (Molecular Devices, Sunnyvale, CA, USA). Para cada amostra, foram adquiridas imagens de 15 campos escolhidos aleatoriamente.

Invadopódios foram caracterizados como protrusões de actina sobrepostas a áreas de digestão (espaços escuros) presentes no substrato de gelatina fluorescente. Mensurações das áreas de digestão foram realizadas utilizando o software de domínio público ImageJ (http://rsb.info.nih.gov/ij/). Empregando o 
recurso de segmentação da imagem ("threshold"), o canal do substrato fluorescente foi processado separadamente, de maneira a ressaltar apenas os espaços escuros na matriz fluorescente. As áreas de degradação foram medidas e expressas em $\mu \mathrm{m}^{2}$, e os valores obtidos foram comparados graficamente. Experimentos realizados em triplicata.

\subsection{Estudo de proteínas relacionadas à formação de invadopódios em células DU145 tratadas pelo peptídeo C16}

\subsubsection{Imunofluorescência}

Células DU145 $\left(2 \times 10^{4}-10^{5}\right)$ foram submetidas a ensaios de degradação de substrato fluorescente e tratadas com os peptídeos C16 e C16SX, conforme descrito anteriormente. Após 16 horas de incubação, células foram fixadas em paraformaldeído 4\% em PBS por 10 minutos e permeabilizadas com Triton X-100 0,05\% (Sigma) em PBS por 5 minutos. Em seguida, foi realizado bloqueio de sítios inespecíficos com soro de cabra 10\% (Kirkegaard \& Perry Laboratories - KPL, Gaithersburg, MD, USA) por 1 hora. As amostras foram então incubadas com anticorpo contra Tks5 (Millipore, diluição 1:500) e com rodamina-faloidina 568 para marcação da actina (diluição 1:2000), incubadas com anticorpos contra MT1-MMP (R\&D Systems, Minneapolis, MN, USA, diluição 1:200) e contra Tks4 (Millipore Corporation, MA, USA, diluição 1:500) ou contra Tks5 (Millipore, diluição 1:500) e cortactina conjugada com Alexa Fluor 555 (Upstate - Millipore, diluição 1:500) por 1 hora à temperatura ambiente. Anticorpos primários foram revelados por anticorpos secundários apropriados conjugados a fluorocromo (Alexa Fluor, Invitrogen - Life Technologies). Montagem das lâminas foi realizada com ProLong Gold (Invitrogen Life Technologies). As imagens foram obtidas igualmente como no ensaio de degradação.

Nestes experimentos, utilizamos fluorocromos que permitiram clara distinção e contraste entre substrato e proteínas estudadas. Células foram crescidas sobre gelatina-FITC (verde), os anticorpos primários anti-Tks4 e anti-Tks5 foram revelados por secundário Alexa-633 ("Far Red", "pseudo-corado" em azul) e o anticorpo antiMT1-MMP foi revelado por Alexa-568 (vermelho). 
A ferramenta Linescan, do software Metamorph, foi utilizada como recurso para melhor evidenciar a colocalização dos canais de marcações das proteínas celulares com as áreas de degradação.

\subsubsection{Immunoblot}

Immunoblot foi utilizado para verificar a expressão das proteínas relacionadas à formação de invadopódios em células DU145 tratadas ou não pelo peptídeo $\mathrm{C} 16$. Células foram cultivadas em placas de 6 poços em meio de cultura suplementado com $0,5 \%$ de SBF contendo o peptídeo C16 ou C16SX diluídos (20$500 \mu \mathrm{g} / \mathrm{ml}$ ). Meio contendo $0,5 \%$ (controle negativo) ou 10\% (controle positivo) de SBF foram utilizados como controles não peptídicos. Células foram incubadas a 37 ${ }^{\circ} \mathrm{C}$ em estufa contendo $5 \%$ de $\mathrm{CO}_{2}$ por 16 horas. Assim, as células foram lisadas em tampão RIPA contendo $50 \mathrm{mM}$ de Tris- $\mathrm{HCl}(\mathrm{pH} 7,5), 150 \mathrm{mM}$ de $\mathrm{NaCl}, 1 \%$ de Triton $\mathrm{X}-100,0,1 \%$ de dodecil sulfato de sódio (SDS), $2 \mathrm{mM}$ de EDTA, $1 \%$ deoxicolato de sódio e coquetel de inibidores de protease e fosfatase (Sigma). Amostras foram então centrifugadas a $10.000 \mathrm{~g}$ por 10 minutos a $4^{\circ} \mathrm{C}$ e o sobrenadante recolhido. Quantificação de proteínas foi realizada através do método BCA (Pierce-Thermo Fisher Scientific Inc., Waltham, MA, USA).

Eletroforese foi realizada seguindo protocolo para SDS-PAGE. Amostras foram ressuspendidas em tampão de amostra ( $3 \%$ dodecil sulfato de sódio, $150 \mathrm{mM}$ Tris $\mathrm{pH} 6.8,15 \%$ mercaptoetanol, 30\% glicerol, 0,01\% azul de bromofenol) e carregadas em gel de poliacrilamida $10 \%(1.5 \mathrm{M}$ Tris- $\mathrm{HCl}, 10 \%$ SDS, $30 \%$ bisacrilamida, 10\% persulfato de amônia e TEMED). Após eletroforese, proteínas foram transferidas para membranas de nitrocelulose (Amersham-GE Healthcare, Piscataway, NJ, USA), que posteriormente foram bloqueadas com $5 \%$ de leite desnatado de diluído em 0,05\% Tween-20 em TBS (TTBS). A membrana foi então incubada com os anticorpos primários contra as proteínas de interesse; Tks4 (Millipore Corporation, MA, USA, diluição 1:1000), Tks5 (Santa Cruz Biotechnology Inc., CA, USA, diluição 1:500), MT1-MMP (Millipore, diluição 1:1000), cortactina fosfo Tir 466 (Santa Cruz, diluição 1:1.000), cortactina (Santa Cruz, diluição 1:1.000), que foram então detectados por anticorpos secundários conjugados com peroxidase (Amersham-GE Healthcare). Protocolo de quimioluminescência (ECL kit, AmershamGE Healthcare) foi utilizado para revelar a reação utilizando o sistema de aquisição 
MF-Chemibis 3.2 (DNR Bio-Image Systems, Jerusalém, ISR) ou filmes radiográficos. Para garantir que a mesma quantidade de proteína foi carregada nos géis, a membrana foi "stripped" e remarcada para $\beta$-actina (Sigma Chemical Co, St Louis, MO, USA).

\subsubsection{Imunoprecipitação}

Para avaliar se o peptídeo C16 influenciaria a fosforilação de Tks5, células DU145 $\left(2 \times 10^{7}\right)$ foram cultivadas em placas de 6 poços em meio contendo $10 \%$ SBF. No dia seguinte, meio completo foi substituído por meio sem soro e células foram mantidas nestas condições por 24 horas. A seguir, células foram incubadas com os peptídeos C16 ou C16SX (20-500 $\mathrm{gg} / \mathrm{ml})$ diluídos em meio contendo 0,5\% SBF a $37^{\circ}$ $\mathrm{C}$ em estufa contendo $5 \%$ de $\mathrm{CO}_{2}$, por 16 horas. Como controles não peptídicos, as células foram incubadas em meio de cultura contendo $0,5 \%$ de SBF (controle negativo) ou $10 \%$ de SBF (controle positivo).

Células foram lisadas em tampão RIPA contendo $50 \mathrm{mM}$ de Tris- $\mathrm{HCl}(\mathrm{pH} 7,5)$, $150 \mathrm{mM}$ de $\mathrm{NaCl}, 1 \%$ de Triton X-100, 0,1\% de dodecil sulfato de sódio (SDS), $2 \mathrm{mM}$ de EDTA, 1\% deoxicolato de sódio e coquetel de inibidores de protease e fosfatase (Sigma). Amostras foram centrifugadas a $10.000 \mathrm{~g} \mathrm{a} 4^{\circ} \mathrm{C}$, sobrenadantes recolhidos e incubados com proteína G-agarose (GE Healthcare) a $4{ }^{\circ} \mathrm{C}$ para "pre-clearing". Após 2 horas, foram centrifugadas novamente a $10.000 \mathrm{~g}$ a $4{ }^{\circ} \mathrm{C}$, sobrenadantes recolhidos e incubados com $1 \mu \mathrm{g}$ de anticorpo contra Tks5 (Santa Cruz) ou $1 \mu \mathrm{gg}$ IgG de coelho para controle a $4{ }^{\circ} \mathrm{C}$ overnight. Após o período, adicionou-se beads proteína G (GE Healthcare) durante 4 horas a $4{ }^{\circ} \mathrm{C}$ para conjugação com o anticorpo de interesse, no caso Tks5. Amostras foram então lavadas três vezes com tampão de lise RIPA; entre cada lavagem foram centrifugadas a $10.000 \mathrm{~g}$ a $4{ }^{\circ} \mathrm{C}$ e o sobrenadante descartado. Finalizada a lavagem, foram resuspendidas em $50 \mu \mathrm{L}$ de tampão de lise RIPA, fervidas por 3 minutos a $100^{\circ} \mathrm{C}$ e logo centrifugadas a $10.000 \mathrm{~g}$ para separação dos beads. O sobrenadante foi recolhido e acrescentou-se $10 \mu \mathrm{L}$ de tampão de amostra para Immublot. Eletroforese realizada segundo o protocolo SDSPAGE. Após eletroforese, proteínas foram transferidas para membranas de nitrocelulose (Amersham-GE Healthcare), que posteriormente foram bloqueadas com 5\% de BSA diluído em 0,05\% Tween-20 em TBS (TTBS). A membrana foi então incubada com os anticorpos primários contra as proteínas de interesse; Tks5 (Santa 
Cruz Biotechnology, diluição 1:500) e p-Tyr clone 4G10 (Millipore, diluição 1:1000) que foram detectados por anticorpos secundários conjugados com peroxidase (Amersham-GE Healthcare). Protocolo de quimioluminescência (ECL kit, Amersham) foi utilizado para revelar a reação utilizando o sistema de aquisição MF-Chemibis 3.2 (DNR Bio-Image Systems, Jerusalém, ISR).

\subsection{Via de sinalização relacionada aos efeitos de C16}

Para analisar se a via de sinalização Src estaria relacionada aos efeitos gerados pelo peptídeo C16, células DU145 foram cultivadas em placas de 6 poços em meio contendo $10 \%$ SBF. No dia seguinte, meio completo foi substituído por meio sem soro e células foram mantidas nestas condições por 24 horas. A seguir, amostras foram incubadas com C16 ou C16SX $(100 \mu \mathrm{g} / \mathrm{ml})$ diluídos em meio contendo $0,5 \%$ SBF em diferentes intervalos de tempo (2-20 minutos), e submetidas a experimentos de immunoblot, conforme descrito anteriormente. Membranas foram incubadas com os anticorpos primários contra Src (Cell Signaling, diluição 1:1000), p-Src (Tir-416, Cell Signaling, diluição 1:1000). A influência de C16 sobre as vias de sinalização foi analisada a partir da observação dos níveis de fosforilação de Src ( $p$ Src, Tir-416), comparada à expressão de Src. $\beta$-actina foi usada como controle de carregamento.

\subsection{Peptídeo C16 e produção de espécies reativas de oxigênio}

\subsubsection{Mensuração da intensidade de fluorescência}

Para analisar a modulação de espécies reativas de oxigênio pelo peptídeo C16, células DU145 $\left(2 \times 10^{4}\right)$ foram cultivadas sobre lamínulas de vidro em meio contendo $0,5 \%$ de SBF e, após período de adesão inicial (1-3 horas), foram tratadas pelo peptídeo C16 $(100 \mu \mathrm{g} / \mathrm{ml})$ ou C16SX $(100 \mu \mathrm{g} / \mathrm{ml})$ diluídos em meio contendo $0,5 \%$ SBF e mantidas a $37{ }^{\circ} \mathrm{C}$ em estufa contendo $5 \%$ de $\mathrm{CO}_{2}$. Utilizamos também controles não peptídicos positivos (meio contendo 10\% de SBF) e negativos (meio com $0,5 \%$ de SBF).

Após 24 horas, células foram delicadamente lavadas com PBS, e incubadas com $2 \mu \mathrm{L}$ da solução de CellRox Deep Red (Life Technologies) e $1 \mu \mathrm{M}$ Hoechst 
33342 (Molecular Probes, Life Technologies), para marcação de núcleo, por 30 minutos a $37^{\circ} \mathrm{C}$ protegidos da luz.

A montagem das lâminas foi feita com PBS aquecido a $37^{\circ} \mathrm{C}$ e amostras foram imediatamente examinadas em microscópio de fluorescência Axiophot (Carl Zeiss), utilizando objetiva PlanApo de $63 \mathrm{x}$ ou 100x e adquiridas no comprimento de onda DAPI e Cy5. Um total de 15 campos aleatórios foram fotografados. Emissão de fluorescência ROS foi analisada através do software público ImageJ, utilizando-se do plugin Color Profile, onde os canais foram processados separadamente, de maneira a ressaltar apenas a marcação de ROS.

\subsubsection{Citometria de Fluxo}

Afim de melhor averiguar a modulação das espécies reativas de oxigênio pelo peptídeo C16, experimento de Citometria de Fluxo foi realizado. Para isso, células DU145 $\left(2 \times 10^{5}\right)$ foram cultivadas em placas de 6 poços em meio de cultura $0,5 \%$ de SBF e, após período de adesão inicial (1-3 horas), foram tratadas pelo peptídeo C16 $(100 \mu \mathrm{g} / \mathrm{ml})$ ou C16SX $(100 \mu \mathrm{g} / \mathrm{ml})$ diluídos em meio contando 0,5\% SBF e mantidas a $37{ }^{\circ} \mathrm{C}$ em estufa contendo $5 \%$ de $\mathrm{CO}_{2}$. Meio contendo $0,5 \%$ (controle negativo) ou 10\% (controle positivo) SBF foram utilizados como controles não peptídicos.

Após 16 horas, células foram removidas das placas por PBS-EDTA 0.5mM, centrifugadas a $13.000 \mathrm{rpm}$ a $18{ }^{\circ} \mathrm{C}$ por 20 segundos e o sobrenadante descartado. Células foram ressuspendidas em $1 \mathrm{~mL}$ de meio de cultura sem soro contendo $2 \mu \mathrm{L}$ do kit comercial CellRox Deep Red (Invitrogen - Life Technologies, concentração final de $5 \mu \mathrm{M}$ ) e incubadas a $37{ }^{\circ} \mathrm{C}$ em estufa contendo $5 \%$ de $\mathrm{CO}_{2}$, por 40 minutos, protegidas da luz. Posteriormente, células foram centrifugadas a $13.000 \mathrm{rpm}$ a $18{ }^{\circ} \mathrm{C}$ por 20 segundos e resuspendidas em $400 \mu \mathrm{L}$ de PBS-BSA 0,5\% contendo $2 \%$ de paraformaldeído e logo analisadas no Citômetro de Fluxo Facs Calibur (Beckton Dickinson and Co., EUA), com leitura para 20.000 eventos. Experimento realizado em triplicata. 


\subsection{Análise Estatística}

Dados obtidos a partir dos experimentos foram analisados usando o software GraphPad Prism 5 (GraphPad Software, Inc., San Diego, CA, USA). Teste t de Student foi utilizado para avaliar diferenças entre dois grupos. Diferenças entre três ou mais grupos foram estimadas através de análise de variância (ANOVA), seguido por teste de comparações múltiplas de Bonferroni. 


\section{RESULTADOS}

\subsection{Peptídeo C16 estimula atividades migratória e invasiva de células derivadas de carcinoma de próstata}

Analisamos os processos de migração celular in vitro, utilizando o sistema de câmaras bipartite separadas por membrana porosa. Após o período de 16 horas, observamos que o peptídeo estimulou aumento da taxa de migração das células DU145 de maneira dose-dependente. Contagem do número células/poço demonstrou que o índice de migração foi até quatro vezes maior nas amostras quando comparadas com as células tratadas com C16SX (Figura 1A). Para os ensaios de invasão, utilizamos o mesmo sistema de câmaras bipartites, porém a membrana porosa foi coberta com Matrigel, a fim de mimetizar a barreira pela qual a célula tumoral atravessa em seu processo metastático. Após o período de 40 horas, observamos que a taxa de invasão das células DU145 também se deu de maneira dose-dependente. Quando as amostras tratadas com peptídeo C16 foram comparadas com as amostras tratadas com peptídeo controle C16SX, notou-se um aumento de até quatro vezes na taxa de invasão sendo significativamente estatístico em todas as concentrações (Figura 1B). Em relação aos controles não peptídicos, os índices de migração e invasão estimulados por C16 foram maiores que o observado nos grupos tratados com $0,5 \%$ SBF (controle negativo) (Figuras $1 \mathrm{~A}$ e 2B, linhas horizontais).

Ensaios de migração e invasão foram realizados pelo menos três vezes, com resultados semelhantes.

\subsection{Peptídeo C16 estimula atividade de invadopódios e a expressão de Tks5 em células DU145. Via Src pode estar relacionada aos eventos}

Tendo em vista que o peptídeo C16 estimulou o aumento das taxas de migração e invasão de células DU145, avaliamos a seguir a sua participação na formação de invadopódios utilizando ensaios de degradação em gelatina fluorescente. Nesse ensaio, a formação de invadopódios foi representada pelos pontos escuros (áreas de digestão) na matriz de gelatina fluorescente (Figura 2A, painel superior). Células DU145 tratadas pelo peptídeo C16 mostraram colocalização de actina e Tks5 nas zonas de digestão do substrato (Figura 2A, 
painel superior). Essa colocalização foi particularmente evidenciada pela ferramenta Linescan (Figura 2A, asterisco no gráfico do painel superior). O gráfico gerado pelo Linescan mostrou picos superpostos dos canais azul e vermelho em contraste à depressão do canal verde, que representa a área de digestão da gelatina. Células tratadas com peptídeo controle C16SX apresentaram discretos focos de digestão (Figura 2A, painel inferior).

Mensurações das áreas de digestão de amostras tratadas com C16 na concentração de $100 \mu \mathrm{g} / \mathrm{ml}$ demonstraram que, em células DU145, a atividade de invadopódios foi cerca de três vezes maior quando comparada ao controle C16SX (Figura 2A, gráfico). Em relação aos controles não peptídicos, a atividade de invadopódios induzida por C16 foi maior que a do controle negativo (Figura 2A, linha horizontal no gráfico).

Estímulos do microambiente tumoral, como o peptídeo C16, promovem a formação de invadopódios através da ativação de vias que sinalizam para a mudança conformacional do citoesqueleto (SIQUEIRA, 2014). A via Src é relacionada com a regulação da atividade e com a expressão de proteínas chaves dos invadopódios (GUARINO, 2010). Verificamos então se o peptídeo C16 seria capaz de estimular a ativação da via de sinalização relacionada à Src, avaliando os níveis de fosforilação desta proteína. Resultados de immunoblot mostraram que C16 estimula a fosforilação de Src em células DU145. O aumento na fosforilação de Src (Tir-416) foi observado cerca de 2 minutos após o tratamento com C16. Taxas significativas de fosforilação de Src foram mantidas por até 20 minutos em células tratadas com C16, o que não foi observado em amostras tratadas com C16SX (Figura 2B). Não foram observadas alterações significativas nos níveis de fosforilação de Src em intervalos de tempos maiores (dados não ilustrados).

\subsection{Peptídeo C16 estimula a expressão de MT1-MMP e Tks4}

Na dinâmica dos invadopódios, Tks4 exerce um papel crucial para regular a principal metaloprotease presente nos invadopódios, a MT1-MMP (MURPHY; COURTNEIDGE, 2011). Diante desses dados, resolvemos analisar a distribuição celular e níveis de expressão de Tks4 e MT1-MMP em células DU145. Amostras de células tratadas com peptídeo C16 foram submetidas a ensaio de degradação e então duplamente marcadas para Tks4 e MT1-MMP. Tks4 apresentou tendência de 
se concentrar na porção central das células (Figura 3A, painel superior). Por sua vez, MT1-MMP encontrou-se amplamente distribuída em células DU145 (Figura 3A, painel superior). Linescan mostrou focos de colocalização entre MT1-MMP e Tks4 nas áreas de digestão da matriz de gelatina (Figura 3A, asterisco no gráfico do painel superior). Nas amostras tratadas por C16SX não foram observadas áreas relevantes de digestão da matriz nem de colocalização entre Tks4 e MT1-MMP (Figura 3A, painel inferior).

Resultados de immunoblot permitiram-nos avaliar melhor os níveis de Tks4 e MT1-MMP nas células tumorais. Para este experimento, células foram tratadas com o peptídeo de interesse em diferentes concentrações por 16 horas. Em células DU145, C16 aumentou os níveis de Tks4 e MT1-MMP em todas as concentrações utilizadas, quando comparado ao peptídeo controle C16SX. No entanto, esse aumento não foi dose-dependente (Figura 3B).

\subsection{Peptídeo C16 estimula a expressão de cortactina e Tks5}

No processo de invasão, sabe-se que Tks5 auxilia no recrutamento de cortactina para a região dos invadopódios (MURPHY; COURTNEIDGE, 2011). Assim, resolvemos analisar a distribuição celular e níveis de expressão de Tks5 e cortactina em células DU145. Células tratadas com peptídeo C16 foram submetidas a ensaio de degradação e posteriormente duplamente marcadas para Tks5 e cortactina. Células DU145 tratadas com C16 exibiram Tks5 e cortactina difusos pelo citoplasma (Figura 4A, painel superior). Colocalização de cortactina e Tks5 foi observada em focos de digestão da matriz de gelatina (Figura 4A, painel superior), conforme mostrado na análise por Linescan (Figura 4A, asterisco no gráfico do painel superior)

Células DU145 tratadas pelo peptídeo controle C16SX exibiram distribuição de Tks5 nas porções centrais, enquanto que cortactina predominava nos domínios periféricos do citoplasma (Figura 4A, painel inferior). Nas amostras tratadas por C16SX não foram observadas áreas relevantes de digestão da matriz nem de colocalização de cortactina e Tks5.

Resultados de immunoblot permitiram-nos avaliar melhor os níveis de Tks5 e cortactina nas células tumorais. Para este experimento, células foram tratadas com o 
peptídeo de interesse em diferentes concentrações por 16 horas. Em células DU145, C16 aumentou os níveis de cortactina e Tks5 em todas as concentrações utilizadas, quando comparado ao peptídeo controle C16SX. No entanto, esse aumento não foi dose-dependente (Figura 4B painel à esquerda).

Sabendo que a fosforilação dos resíduos de tirosina Tks5 é um importante evento para a formação dos invadopódios, observamos o efeito de C16 sobre fosforilação dessa molécula. Amostras tratadas com o peptídeo C16 por 16 horas, foram imunoprecipitadas com o anticorpo contra Tks5 e posteriormente submetidas à immunoblot para marcação com anticorpo contra p-Tir (clone 4G10). Observamos que houve um aumento da marcação para Tirosina fosforilada no tratamento com C16 na concentração de $100 \mu \mathrm{g} / \mathrm{ml}$, o que não ocorreu nas demais concentrações (Figura 4B, painel à direita).

\subsection{C16 modula a formação de espécies reativas de oxigênio em derivadas de carcinoma prostático}

Espécies reativas de oxigênio (ROS) contribuem para a formação de invadopódios, que resulta em um fenótipo tumoral ainda mais invasivo (WEAVER, 2009). Para avaliarmos os efeitos de C16 sobre a geração de espécies reativas, células DU145 foram plaqueadas em lamínulas e tratadas com o peptídeo por 16 horas. Utilizando-se o kit comercial CellRox Deep Red (Invitrogen), pudemos avaliar a emissão de fluorescência de ROS que foi produzido. As células foram fotografadas (Figuras 5A e B) e a mensuração da fluorescência foi realizada através do plugin Color Profile, do software ImageJ. Observamos que houve um aumento significativo das espécies reativas de oxigênio em até duas vezes comparado ao peptídeo controle (Figura 5C). Isso sugere que o peptídeo modulou a produção de ROS. Com o intuito de confirmar os resultados, adicionalmente avaliamos a modulação das espécies reativas de oxigênio por citometria de Fluxo. Células foram tratadas com o peptídeo C16 por 16, ressuspendidas, marcadas por CellRox Deep Red (Invitrogen), e analisadas no citômetro Facs Calibur. Os resultados foram complementares aos anteriores, comprovando a ação do peptídeo na geração de ROS (Figura 5D). Amostras tratadas com controle C16SX exibiram uma menor produção de ROS em ambos experimentos. 
Figura 5.1

\begin{abstract}
Peptídeo C16 estimula as atividades migratória e invasiva de células DU145. Nos ensaios de migração e invasão, contagem do número de células/poço revela que C16 induz migração e invasão de células DU145 comparado ao controle C16SX (A e B). Os fenômenos são dose-dependente. Asteriscos em A e B indicam diferenças estatisticamente significantes entre os grupos C16 e C16SX ( $p<0,05)$. Linhas horizontais representam média das taxas de migração e invasão dos grupos controles não peptídicos positivo (10\% SBF) e negativo ( $0,5 \%$ SBF). Resultados representam média \pm erro da média de três experimentos.
\end{abstract}


Ensaio de Migração

A

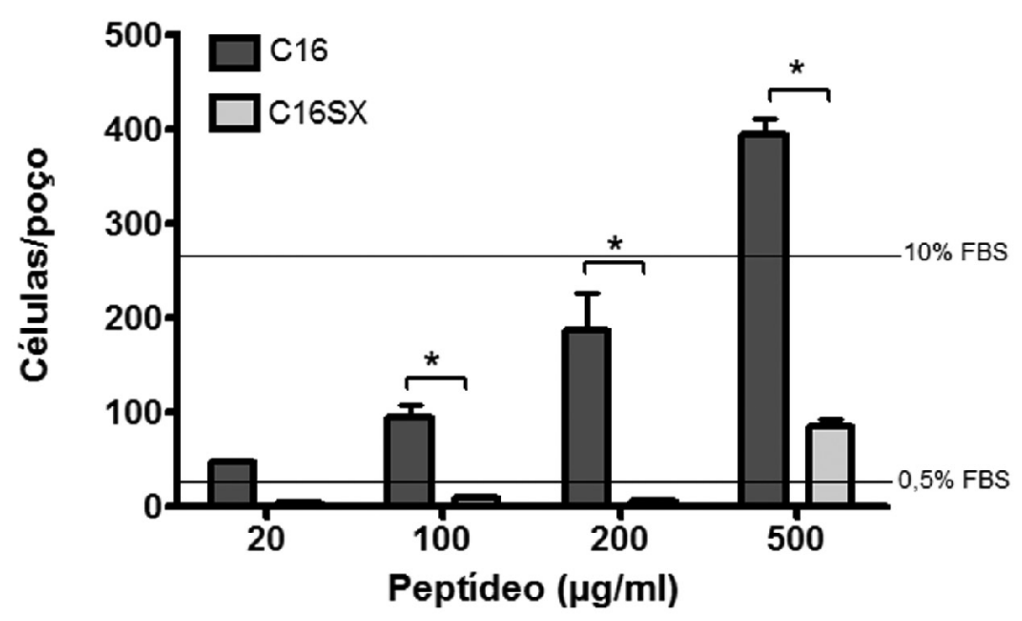

Ensaio de Invasão
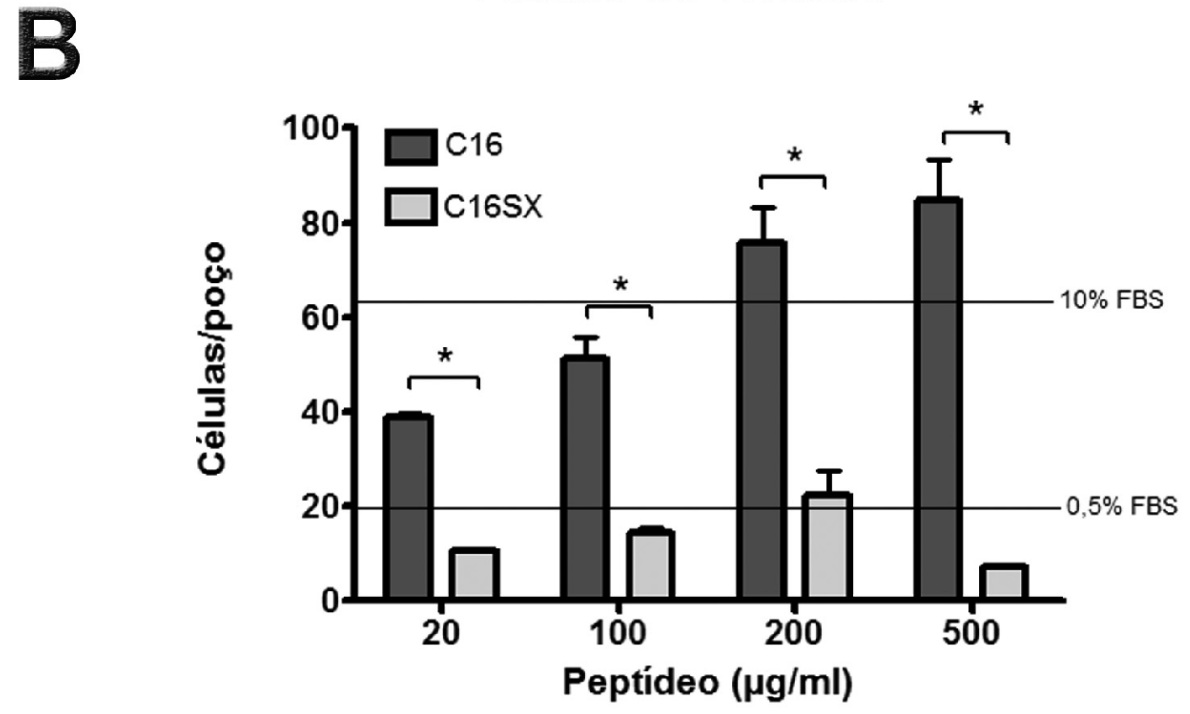

Figura 5.1 - Peptídeo C16 estimula as atividades migratória e invasiva em células DU145 de maneira dose-dependente 
Figura 5.2

C16 estimula a atividade de invadopódios e a expressão de Tks5 em células DU145. Via Src pode estar relacionada com os eventos. Ensaios de degradação de substrato fluorescente (A). Nesse ensaio, a formação de invadopódios é representada pelos pontos escuros (áreas de digestão) na matriz de gelatina fluorescente (A, painel superior). Células DU145 tratadas pelo peptídeo C16 mostram colocalização de actina e Tks5 nas zonas de digestão do substrato, evidenciada pela ferramenta Linescan ( $A$, asterisco no gráfico do painel superior). $O$ gráfico gerado pelo Linescan mostra picos superpostos dos canais azul e vermelho em contraste à depressão do canal verde, que representa a área de digestão da gelatina. Células tratadas com peptídeo controle C16SX apresentam discretos focos de digestão (A, painel inferior). Immunoblot demonstra que C16 estimula a fosforilação de Src (B) após dois minutos de tratamento. Escalas em A: $10 \mu \mathrm{m}$. 

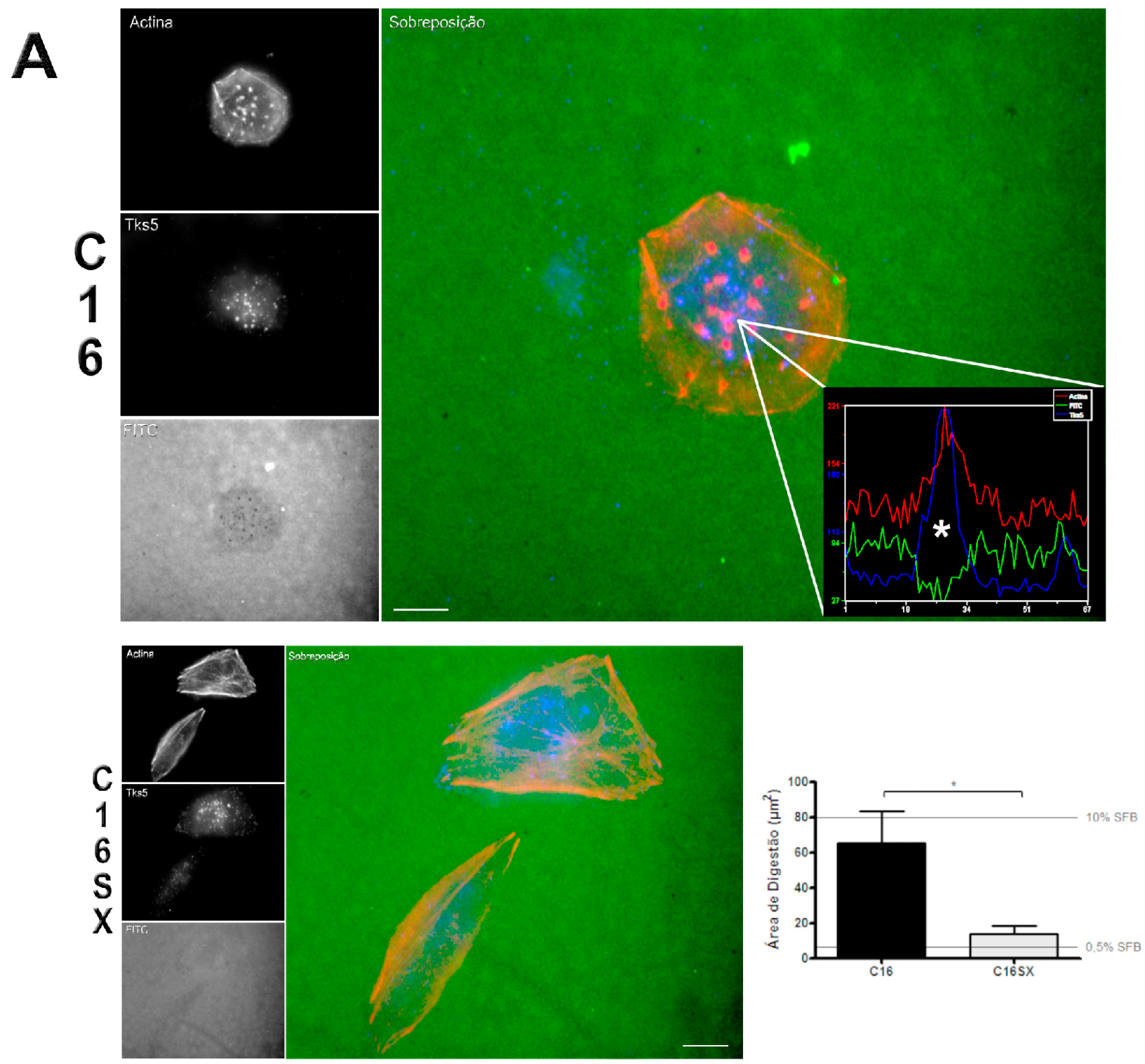

B

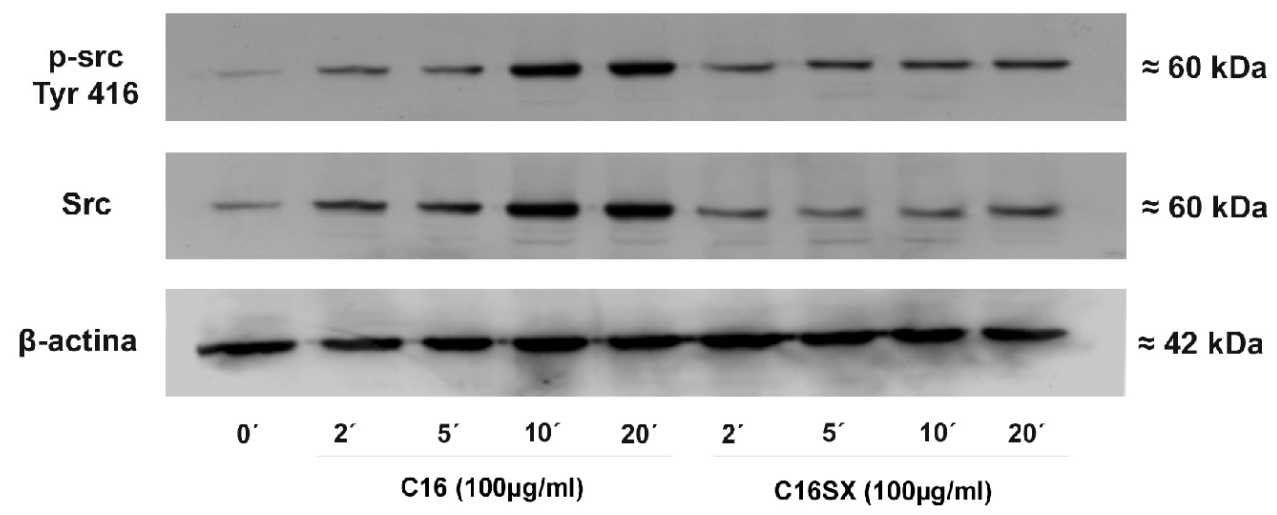

Figura 5.2 - C16 estimula a atividade de invadopódios e a expressão de Tks5 em células DU145. Via Src pode estar relacionada com os eventos 
Figura 5.3

\section{O peptídeo C16 estimula a expressão de Tks4 e MT1-MMP de células DU145.} Tks4 apresenta tendência de se concentrar na porção central das células (A, painel superior). Por sua vez, MT1-MMP encontra-se amplamente distribuída em células DU145 (A, painel superior) (A). Colocalização de MT1-MMP e Tks4 é evidenciada nos painéis de sobreposição e no Linescan (asterisco no gráfico do painel superior). Nas amostras tratadas por C16SX não são observadas áreas relevantes de digestão da matriz nem de colocalização entre Tks4 e MT1-MMP (A, painel inferior). Immunoblot revela que C16 estimula a expressão de MT1-MMP e de Tks4, comparados a C16SX (B). Esse aumento não é dose-dependente. Escalas em A: 10 $\mu \mathrm{m}$. 

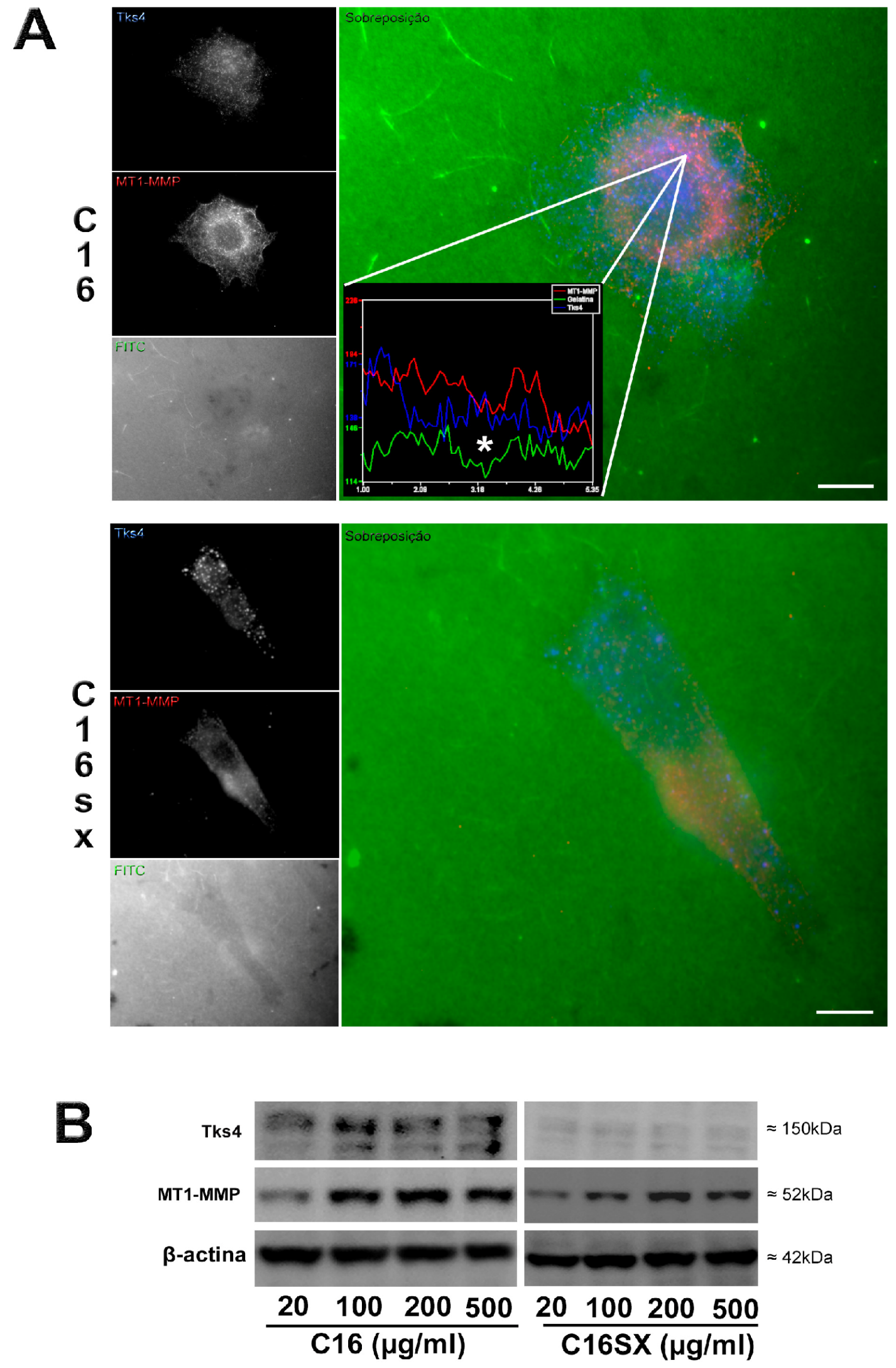

Figura 5.3 - O peptídeo C16 estimula a expressão de Tks4 e MT1-MMP de células DU145 
Figura 5.4

O peptídeo C16 estimula a expressão de cortactina e Tks5. Células DU145 tratadas com $\mathrm{C} 16$ exibem Tks5 e cortactina difusos pelo citoplasma (A, painel superior). Colocalização de cortactina e Tks5 é observada em focos de digestão da matriz de gelatina, conforme mostrado na análise por Linescan (A, asterisco no gráfico do painel superior). Células DU145 tratadas pelo peptídeo controle C16SX apresentam distribuição de Tks5 nas porções centrais, enquanto que cortactina predomina nos domínios periféricos do citoplasma (A, painel inferior). Nas amostras tratadas por C16SX não exibem áreas relevantes de digestão da matriz nem de colocalização de cortactina e Tks5. (A, painel inferior). Immunoblot revela que C16 estimula a expressão de Tks5 e cortactina ( $B$, painel à esquerda), bem com a fosforilação de resíduos de tirosina de Tks5 (B, painel à direita). Escalas em $A: 10$ $\mu \mathrm{m}$. 

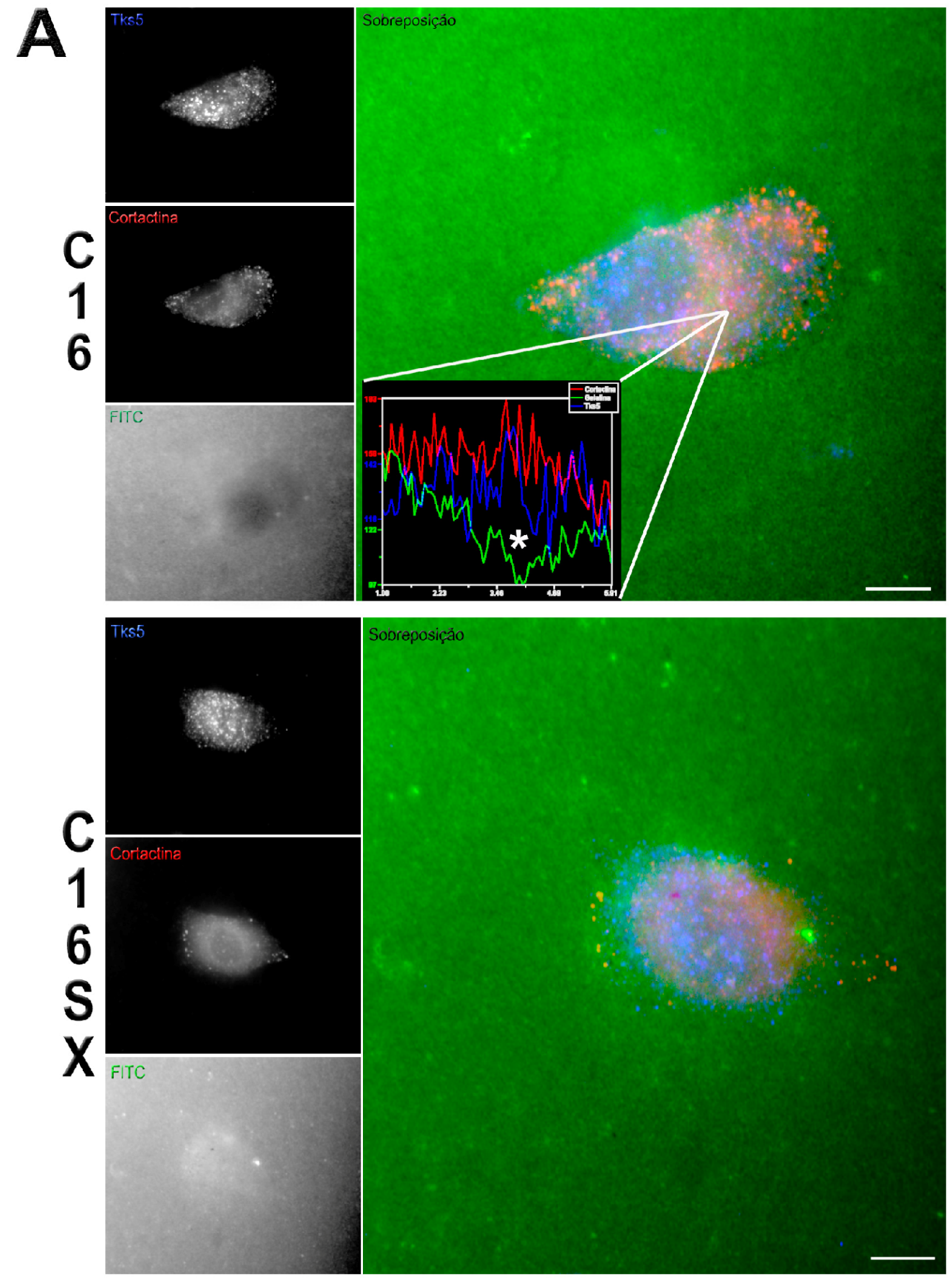

\section{B}

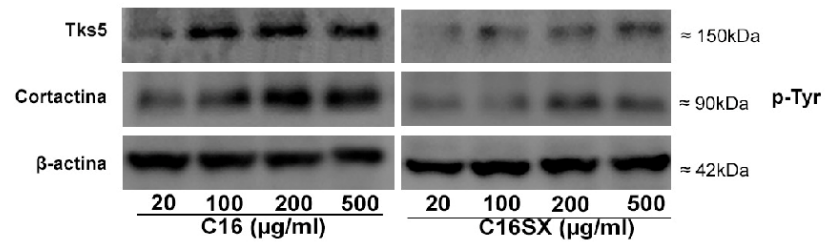

IP: Tks5

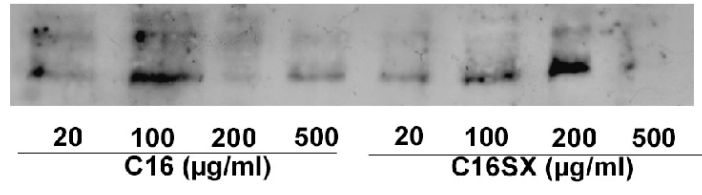

Figura 5.4 - Peptídeo C16 estimula a expressão de cortactina e p-Tks5 
Figura 5.5

O peptídeo C16 modula a produção de espécies reativas de oxigênio em células DU145. Células tratadas com peptídeo $\mathrm{C} 16$ exibem pronunciada marcação de fluorescência para ROS quando comparadas ao grupo de células tratado com C16SX ( $A$ e B). Mensuração da intensidade de fluorescência nos mostra que há um aumento em até duas vezes da produção de ROS (C). Asteriscos em A e B indicam diferenças estatisticamente significantes entre os grupos C16 e C16SX $(p<0,05)$. Linhas horizontais representam média da intensidade de fluorescência o dos grupos controles não peptídicos positivo (10\% SBF) e negativo (0,5\% SBF) (C). Resultados representam média \pm erro da média de três experimentos. Citometria de fluxo confirma esse resultado, revelando aumento na geração de ROS no grupo tratado com C16 (D). Escalas: $10 \mu \mathrm{m}$. 


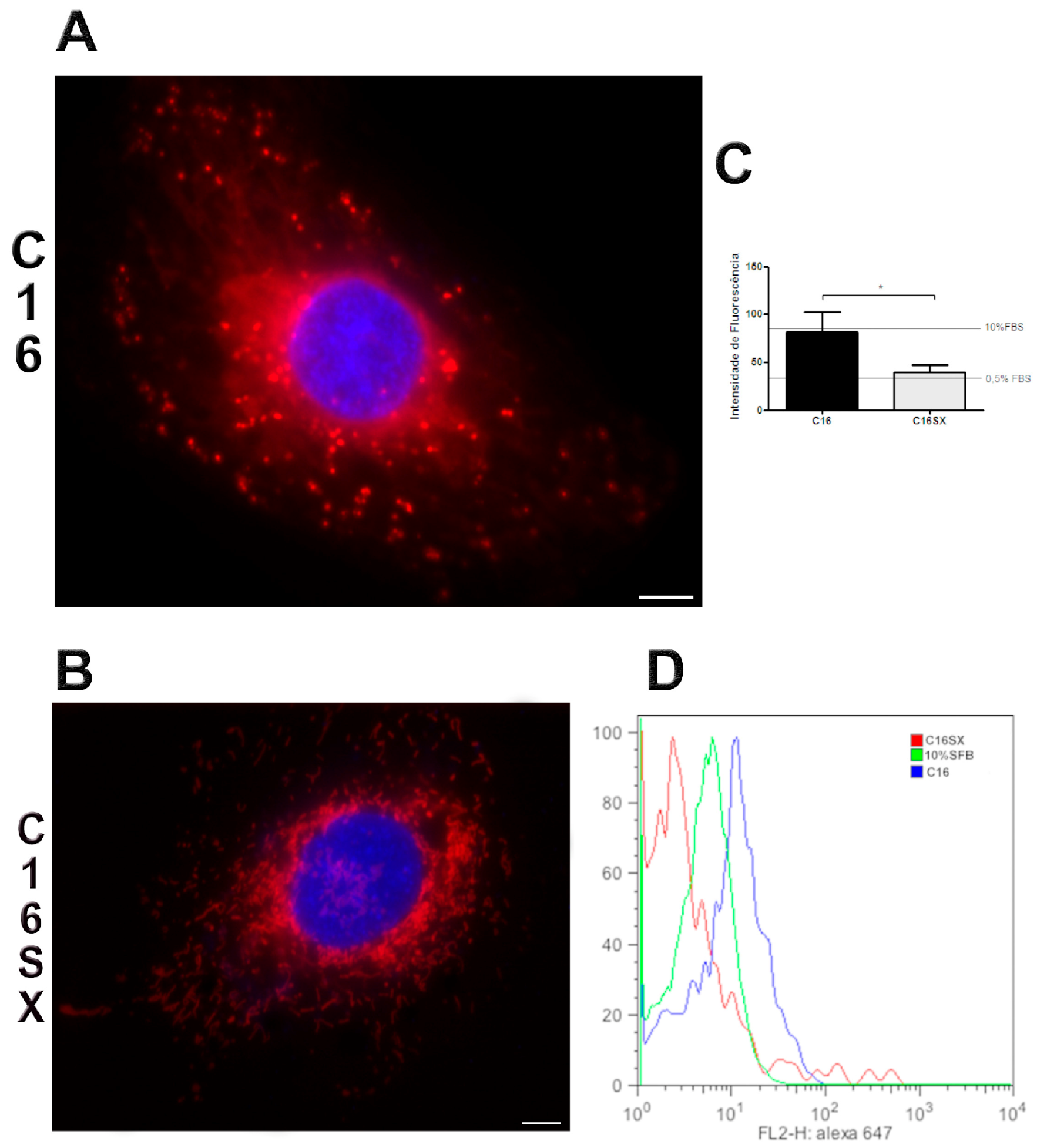

Figura 5.5 - Peptídeo C16 modula a geração de espécies reatvas de oxigênio em células DU145 


\section{DISCUSSÃO}

Demonstramos neste trabalho, que o peptídeo $\mathrm{C} 16$, derivado da cadeia $\gamma 1 \mathrm{da}$ laminina, estimula migração, invasão, bem como a atividade de invadopódios em linhagem celular derivada de carcinoma prostático (DU145). C16 promoveu aumento das áreas de degradação relacionadas à atividade de invadopódios e estimulou a expressão de Tks4, Tks5, cortactina e MT1-MMP, que são proteínas marcadoras de invadopódios. Buscamos também elucidar possíveis mecanismos regulatórios envolvidos nos efeitos mediados por C16 em células DU145. Verificamos que este peptídeo promove a fosforilação/ativação da via de sinalização Src. Adicionalmente, observamos que C16 modulou geração de espécies reativas de oxigênio (ROS) nas células tumorais da próstata. Nosso grupo já havia investigado os efeitos desse peptídeo em outra linhagens tumorais (NASCIMENTO et al., 2011; SIQUEIRA, 2014). Para nosso conhecimento, este é o primeiro trabalho mostrando que o peptídeo C16, derivado da laminina, regula migração, invasão, invadopódios e suas moléculas-chave, bem como geração de espécies reativas de oxigênio em células tumorais prostáticas

Sabe-se que o microambiente circundante do tumor está relacionado com o seu comportamento biológico (ZENG et al., 2013). Durante a invasão tumoral, as células neoplásicas penetram a parede dos vasos sanguíneos e linfáticos, rompem a membrana basal e atravessam para o lúmen do vaso para disseminar e formar metástase em órgãos distantes do sítio primário de desenvolvimento (FIDLER, 2003). A disseminação tumoral envolve interações das células neoplásicas com componentes da MEC, onde as moléculas da matriz podem regulam as funções células tumorais a medida que elas cruzam a membrana basal e o estroma intersticial (COMOGLIO; TRUSOLINO, 2005).

A matriz extracelular (MEC) é composta por grande variedade de moléculas estruturais, como colágenos, glicoproteínas não colágenas e proteoglicanos, que desempenham um papel crucial na regulação do comportamento das células com que faz contato, influenciando seu desenvolvimento, crescimento, sobrevivência, migração, forma e função (MINER; YURCHENCO, 2004a; YURCHENCO; O'REAR, 1994).

A lâmina basal, uma fina camada de MEC especializada, é produzida por células na interface epitélio-tecido conjuntivo e não atua apenas como suporte para 
as células, mas também como fonte de citocinas, fatores de crescimento e tem participação ativa em funções celulares como morfogênese tecidual, adesão, migração, crescimento e diferenciação celulares (AUMAILLEY et al., 2005; COLOGNATO; YURCHENCO, 2000; YURCHENCO et al., 2004).

Moléculas que compõe a membrana basal e a matriz extracelular apresentam em sua estrutura íntegra sítios escondidos que em condições fisiológicas, não estão expostos. Estes sítios possuem funções biológicas e geralmente são expostos através da proteólise, dando origem a fragmentos e peptídeos bioativos (MOTT; WERB, 2004; SCHENK; QUARANTA, 2003). Durante o processo de metástase, sabe-se que as células tumorais utilizam-se de enzimas proteolíticas para quebra da membrana basal para invasão. Neste evento, as células tumorais ficam expostas aos componentes da MEC, bem como aos peptídeos bioativos derivados, que regulam funções celulares (SIQUEIRA et al., 2010; WILSON et al., 1999).

Dentre as proteínas da membrana basal, a laminina possui múltiplos sítios crípticos relacionados com diferentes atividades biológicas incluindo adesão, migração, diferenciação, angiogênese e secreção de proteases (FREITAS; JAEGER, 2002; FREITAS et al., 2004; GRANT et al., 1992). A proeminente expressão de laminina na membrana basal pode influenciar a invasão tumoral, especialmente quando há seu rompimento, onde peptídeos com atividades biológicas podem ser liberados (AUMAILLEY et al., 2005; GIVANT-HORWITZ; DAVIDSON; REICH, 2005). Nosso laboratório já demonstrou que o $\mathrm{C} 16$, um dos peptídeos derivados da proteólise da laminina-111, regula migração, invasão e secreção de proteases em células derivadas de carcinoma adenóide cístico (FREITAS; JAEGER, 2002; GAMADE-SOUZA et al., 2008).

O peptídeo C16 (KAFDITYVRLKF) utilizado em nossos experimentos é derivado da laminina-111, localizado no braço curto da cadeia $\gamma 1$, no primeiro domínio globular (KURATOMl et al., 2002; NOMIZU et al., 1997). A cadeia $\gamma 1$ está presente na maioria das isoformas de laminina, exceto a 332 (antiga laminina 5) (COLOGNATO; YURCHENCO, 2000; NOMIZU et al., 1997). Em tumores de próstata de alta agressividade, há uma proeminente expressão de laminina-511 (antiga laminina 10), que contém a cadeia $\gamma 1$ (STEWART; COOPER; SIKES, 2004). Os estudos nos induzem a concluir que no processo de invasão tumoral prostático, temse a proteólise da laminina e liberação de peptídeos bioativos, como o C16. Os 
eventos que promovem o crescimento do tumor, como a adesão celular e diferenciação, a angiogênese, a migração e a secreção de MMP em células de melanoma foram relacionados com o peptídeo C16 (KURATOMl et al., 2002; NOMIZU et al., 1997; PONCE; KLEINMAN, 2003; PONCE; NOMIZU; KLEINMAN, 2001). Sendo este trabalho o primeiro registro da interação do peptídeo C16 com células tumorais prostáticas, resolvemos investigar então se este peptídeo exerce algum papel na biologia tumoral da linhagem estudada. Observamos que o tratamento com o peptídeo C16 estimulou a migração e o fenótipo invasivo de células de câncer de próstata de maneira dose-dependente, demonstrando que este peptídeo pode induzir mecanismos relacionados com a progressão de células tumorais prostáticas.

Em quase todos os estágios de disseminação do tumor, a reorganização do citoesqueleto de actina se faz necessário para o comportamento das células invasivas, como a perda do contato célula-célula, aumento da mobilidade celular e a formação de protrusões de membrana (NURNBERG; KITZING; GROSSE, 2011). Essas protrusões são chamadas de invadopódios e estão presentes em células tumorais invasivas. São estruturas dinâmicas, ricas em actina circundadas por proteínas adesivas e estruturais, que formam-se ventralmente nas células e se estendem verticalmente para a MEC (COURTNEIDGE, 2012; GIMONA et al., 2008; LINDER, 2007). Eles distinguem-se de outras estruturas de adesão celular devido à sua associação com atividade proteolítica e polimerização da actina (MURPHY; COURTNEIDGE, 2011).

Os invadopódios já foram identificados em linhagem celular derivadas de melanoma, carcinoma de mama e carcinoma adenóide cístico (CLARK et al., 2007; NASCIMENTO et al., 2011). Ensaios para detectar a atividade dos invadopódios in vitro envolvem o cultivo de células sobre lamínulas cobertas com substratos fluorescentes de gelatina (colágeno denaturado), ou derivados de proteínas da MEC (como fibronectina) (ARTYM et al., 2006). Por meio deste ensaio, verificamos que C16 induziu a atividade de invadopódios em células DU145. Além deste ensaio, através da ferramenta Linescan, pode-se melhor visualizar a intensidade da fluorescência emitida pelas amostras, onde nas áreas de degradação há um aumento significativo da fluorescência do canal marcado para actina e uma grande diminuição de fluorescência do canal marcado para a gelatina. Estes resultados nos 
mostram o acúmulo da actina nas áreas focais de degradação, em contraste à proteólise da gelatina.

Estímulos extracelulares como peptídeos da laminina e outros componentes da MEC, podem promover a ativação de moléculas associadas aos invadopódios por meio de vias de sinalização celular (NASCIMENTO et al., 2011; SIQUEIRA et al., 2010). Src quinase participa de uma variedade de funções celulares como proliferação celular, migração e invasão e está superexpresso nos cânceres de próstata de estágio mais avançado (BURGER et al., 2014; GUARINO, 2010). Essa molécula também está envolvida em diferentes eventos relacionados à formação de invadopódios (DESTAING et al., 2008; KELLEY et al., 2010). Demonstramos neste trabalho que C16 estimula a fosforilação do resíduo de tirosina 416 de Src em células DU145 após poucos minutos de tratamento. A fosforilação da tirosina 416 permite o acesso de Src aos seus substratos. Entre esses substratos destacamos Tks4 e Tks5, envolvidos na formação dos invadopódios (COURTNEIDGE et al., 2005).

Proteínas ligantes e nucleadoras de actina, ativadores de polimerização, quinases e pequenas GTPases regulam a maquinaria dos invadopódios (GIMONA et al., 2008). As moléculas chaves do processo de formação dos invadopódios são Tks4, Tks5, cortactina e MT1-MMP (AYALA et al., 2009; BUCCIONE; CALDIERI; AYALA, 2009; CLARK et al., 2007; CRIMALDI; COURTNEIDGE; GIMONA, 2009).

A MT1-MMP é uma metaloprotease (MMP) de membrana que está envolvida com a degradação da MEC, exercendo essa atividade nos invadopódios (ARTYM et al., 2006). Possui papel dominante na migração e invasão de células metastáticas e sua localização em invadopódios é um fator essencial para a maturação das estruturas (MURPHY; COURTNEIDGE, 2011; SABEH et al., 2009). Além disso, MT1-MMP possui papel importante na quebra estrutural do colágeno no processo de invasão de células tumorais, bem como participa da clivagem das lamininas-111 e 511, que são formadas pela cadeia $\gamma 1$ da laminina (BAIR et al., 2005; OHUCHI et al., 1997). Sabe-se que Tks4 é responsável pela regulação e secreção de MT1-MMP nos invadopódios. Estudos mostram que a inibição de Tks4 permite a formação dos invadopódios, porém não há o acúmulo de MT1-MMP nas estruturas e consequentemente, não há proteólise local da MEC.

Partindo do pressuposto que MT1-MMP participa da proteólise controlada da matriz extracelular, poderíamos especular que essa enzima geraria fragmentos da 
laminina-111 contendo o peptídeo C16. Adicionalmente, Tks4 é determinante para função de MT1-MMP nos invadopódios. Dessa forma, resolvemos avaliar se C16 promove o aumento da expressão de MT1-MMP e de Tks4 em células DU145. Através de immnunoblot de células DU145 tratadas com o peptídeo C16, verificamos que a expressão de Tks4 e MT1-MMP aumentou a partir do tratamento com o peptídeo na concentração de $100 \mu \mathrm{g} / \mathrm{ml}$. No entanto, doses maiores do peptídeo não resultaram no aumento da expressão de Tks4 e MT1-MMP.

O resultado de expressão protéica de Tks4 induzido por C16 foi diferente do efeito dose-dependente do peptídeo na migração e invasão de células DU145. Tomando nossos resultados em conjunto, podemos inferir que há uma concentração ideal $(100 \mu \mathrm{g} / \mathrm{ml})$ para saturação dos receptores, que sinalizam posteriormente para promover a síntese de Tks4 e MT1-MMP. Podemos especular que C16 inicialmente induziria aumento da expressão dessas proteínas formadoras dos invadopódios até atingir estabilidade no seu nível de expressão. Doses maiores que $100 \mu \mathrm{g} / \mathrm{ml}$ poderiam induzir redistribuição de Tks4 e MT1-MMP para diferentes locais da membrana. Isso resultaria em aumento da formação de invadopódios e invasão celular, independente da síntese de Tks4 e MT1-MMP.

Além da expressão protéica, verificamos também a localização de Tks4 e MT1-MMP nos invadopódios. Células DU145 foram tratadas com o peptídeo C16 na concentração de $100 \mu \mathrm{g} / \mathrm{ml}$ e submetidas ao ensaio de degradação em substrato fluorescente, com posterior marcação para os anticorpos contra MT1-MMP e Tks4. Os resultados nos mostram que há acúmulo e colocalização das duas proteínas nas áreas de degradação da gelatina. Esse dado é corroborado pela literatura (BUSCHMAN et al., 2009) mostrando que Tks4 tem papel para a regulação de MT1MMP.

A proteína Tks5 participa dos processos de iniciação e de maturação dos invadopódios. Sabe-se que a interação entre Tks5 e cortactina é crucial para a para a formação dos invadopódios, pois desempenham papel crucial no processo de remodelamento do citoesqueleto, permitindo formar protrusões de membrana que mergulham verticalmente na MEC (FEKETE et al., 2013; SHARMA et al., 2013).. Estudos mostram que Tks5 colocaliza com a actina e cortactina em áreas de digestão pericelular (SEALS et al., 2005). Adicionalmente, depleção de Tks5 inibe tanto a formação de invadopódios quanto o recrutamento de cortactina a esses sítios de invasão (CRIMALDI; COURTNEIDGE; GIMONA, 2009; SHARMA et al., 2013; 
YAMAGUCHI et al., 2005). Em condições fisiológicas, Tks5 encontra-se difuso no citoplasma. Por outro lado, em células tumorais observa-se um acúmulo dessa molécula nas áreas dos invadopódios (MURPHY et al., 2011; MURPHY; COURTNEIDGE, 2011). Amostras de tecidos tumorais de próstata mostram correlação entre aumento na expressão de Tks5 e aumento do Score de Gleason. Isso mostra que quanto maior a agressividade do tumor, maior a expressão de Tks5 (BURGER et al., 2014).

Partindo destas informações, analisamos se C16 influenciaria a expressão de Tks5 e cortactina nas células DU145. Immnunoblot mostrou que C16 aumenta os níveis de Tks5 e cortactina na concentração de $100 \mu \mathrm{g} / \mathrm{ml}$. Doses maiores do peptídeo não resultaram no aumento da expressão dessas moléculas. Esses resultados são semelhantes aos observados para as proteínas Tks4 e MT1-MMP e também são diferentes do que foi verificado nos ensaios de migração e invasão. Também podemos especular que C16 inicialmente induziria aumento da expressão dessas proteínas formadoras dos invadopódios até atingir estabilidade no seu nível de expressão. Doses maiores que $100 \mu \mathrm{g} / \mathrm{ml}$ induziriam redistribuição de Tks5 e cortactina para diferentes locais da membrana. Isso resultaria em aumento da formação de invadopódios e invasão celular, independente da síntese de dessas moléculas.

Além da expressão protéica, verificamos também a localização de Tks4 e MT1-MMP nos invadopódios. Células DU145 foram tratadas com o peptídeo C16 na concentração de $100 \mu \mathrm{g} / \mathrm{ml}$ e marcadas com o anticorpo contra Tks5. Os resultados nos revelaram que a proteína Tks5 concentra-se nos locais de degradação da gelatina (pontos escuros) e também as áreas de concentração de actina. Já nas células tratadas com o peptídeo C16SX, Tks5 apresenta-se mais difuso no citoplasma. Adicionalmente, estudamos a localização de Tks5 e cortactina realizando o mesmo ensaio de degradação. Observamos colocalização entre Tks5 e cortactina nas áreas de degradação da matriz fluorescente. A ferramenta Linescan nos auxiliou para melhor análise dos canais das proteínas marcadas, evidenciando uma sobreposição e um aumento da fluorescência de Tks5 e cortactina nas áreas onde há perda da fluorescência do canal da gelatina, evidenciando a degradação.

Adicionalmente, sabe-se que Tks5 possui inúmeros resíduos de tirosina entre o terceiro e quarto domínio SH3, que se assemelham a sítios de fosforilação conhecidos de outros substratos de Src (LOCK et al., 1998). Estudos em linhagem 
de câncer de próstata mostram que a fosforilação de Tks5 é importante para o fenótipo invasivo das células (BURGER et al., 2014). Demonstramos neste trabalho que $\mathrm{C} 16$, na concentração de $100 \mu \mathrm{g} / \mathrm{ml}$, é capaz de promover a fosforilação de resíduos de Tks5, possivelmente através dos mecanismos ativados de Src.

Optamos por estudar também as espécies reativas de oxigênio (ROS), outro importante mecanismo que contribui para a formação dos invadopódios. O estresse metabólico e a mudança fisiológica celular auxiliam na produção de ROS em células tumorais, que promove modificações não só em seu DNA, mas também em vias de sinalização para mudança estrutural (WARIS; AHSAN, 2006). ROS pode auxiliar no aumento da expressão de MMPs, permitindo um maior remodelamento da MEC, ou mesmo modular Src, ativando reguladores dos invadopódios. Neste trabalho, constatou-se através de fluorescência e citometria de fluxo que C16 regulou positivamente a produção de espécies reativas de oxigênio em comparação ao grupo tratado com C16SX. Sabe-se ainda que Tks5 compartilha similaridades em sua estrutura com Nox, uma proteína organizadora que promove a ativação do complexo p47phox que auxilia na produção de ROS. Tks5 pode ativar o complexo e gerar ainda mais espécies reativas de oxigênio, o que contribui para a invasão das células tumorais (WEAVER, 2009). Tomados em conjunto, nossos resultados sugeriram que C16 estimularia Tks5, com posterior geração de espécies reativas de oxigênio (ROS).

Estímulos extracelulares como peptídeos da laminina e outras moléculas da matriz extracelular, podem promover atividades biológicas que contribuem para a capacidade de invasão tumoral. Em conjunto, os nossos resultados sugerem que o peptídeo C16, derivado da laminina, estimula a migração, invasão e atividade de invadopódios em células DU145. Adicionalmente, esse peptídeo regula Src e influencia a expressão de moléculas-chave dos invadopódios, como Tks4, Tks5 e MT1-MMP. Finalmente, verificamos que o peptídeo C16 modula espécies reativas de oxigênio. Esses eventos podem ser relevantes para melhor conhecimento da biologia do câncer prostático. 


\section{CONCLUSÕES}

Baseados nos resultados dos experimentos realizados, concluímos que:

1) Peptídeo $\mathrm{C} 16$, derivado da laminina, promove aumento nas atividades migratória e invasiva de células de carcinoma prostático (DU145)

2) C16 estimula atividade de invadopódios em células DU145.

3) C16 aumento o nível de Tks4, Tks5, MT1-MMP e cortactina, que são proteínas chaves para o processo de formação dos invadopódios

4) C16 estimula a ativação da via de sinalização Src

5) C16 induz a produção de espécies reativas de oxigênio em células DU145 


\section{REFERÊNCIAS*}

ABRAM, C. L.; SEALS, D. F.; PASS, I.; SALINSKY, D.; MAURER, L.; ROTH, T. M.; COURTNEIDGE, S. A. The adaptor protein fish associates with members of the ADAMs family and localizes to podosomes of Src-transformed cells. J. Biol. Chem., v. 278, n. 19, p. 16844-16851, 2003.

ARTYM, V. V.; ZHANG, Y.; SEILLIER-MOISEIWITSCH, F.; YAMADA, K. M.; MUELLER, S. C. Dynamic interactions of cortactin and membrane type 1 matrix metalloproteinase at invadopodia: defining the stages of invadopodia formation and function. Cancer Res., v. 66, n. 6, p. 3034-3043, 2006.

AUMAILLEY, M.; BRUCKNER-TUDERMAN, L.; CARTER, W. G.; DEUTZMANN, R.; EDGAR, D.; EKBLOM, P.; ENGEL, J.; ENGVALL, E.; HOHENESTER, E.; JONES, J. C.; KLEINMAN, H. K.; MARINKOVICH, M. P.; MARTIN, G. R.; MAYER, U.; MENEGUZZI, G.; MINER, J. H.; MIYAZAKI, K.; PATARROYO, M.; PAULSSON, M.; QUARANTA, V.; SANES, J. R.; SASAKI, T.; SEKIGUCHI, K.; SOROKIN, L. M.; TALTS, J. F.; TRYGGVASON, K.; UITTO, J.; VIRTANEN, I.; VON DER MARK, K.; WEWER, U. M.; YAMADA, Y.; YURCHENCO, P. D. A simplified laminin nomenclature. Matrix Biol., v. 24, n. 5, p. 326-332, 2005.

AUMAILLEY, M.; SMYTH, N. The role of laminins in basement membrane function. J. Anat., v. 193, p. 1-21, 1998.

AYALA, I.; BALDASSARRE, M.; CALDIERI, G.; BUCCIONE, R. Invadopodia: a guided tour. Eur. J. Cell Biol., v. 85, n. 3-4, p. 159-164, 2006.

AYALA, I.; GIACCHETTI, G.; CALDIERI, G.; ATTANASIO, F.; MARIGGIO, S.; TETE, S.; POLISHCHUK, R.; CASTRONOVO, V.; BUCCIONE, R. Faciogenital dysplasia protein Fgd1 regulates invadopodia biogenesis and extracellular matrix degradation and is up-regulated in prostate and breast cancer. Cancer Res., v. 69, n. 3, p. 747752, 2009.

BAIR, E. L.; CHEN, M. L.; MCDANIEL, K.; SEKIGUCHI, K.; CRESS, A. E.; NAGLE, R. B.; BOWDEN, G. T. Membrane type 1 matrix metalloprotease cleaves laminin-10 and promotes prostate cancer cell migration. Neoplasia, v. 7, n. 4, p. 380-389, 2005.

BIRK, D. E.; MAYNE, R. Localization of collagen types I, III and V during tendon development. Changes in collagen types I and III are correlated with changes in fibril diameter. Eur. J. Cell. Biol., v. 72, n. 4, p. 352-361, 1997.

BLOUW, B.; SEALS, D. F.; PASS, I.; DIAZ, B.; COURTNEIDGE, S. A. A role for the podosome/invadopodia scaffold protein Tks5 in tumor growth in vivo. Eur. J. Cell Biol., v. 87, n. 8-9, p. 555-567, 2008.

\footnotetext{
* De acordo com:

ASSOCIAÇÃO BRASILEIRA DE NORMAS TÉCNICAS. NBR 6023: informação e documentação: referências: elaboração. Rio de Janeiro, 2002.
} 
BORNSTEIN, P. Cell-matrix interactions: the view from the outside. Methods Cell Biol., v. 69, p. 7-11, 2002.

BOSMAN, F. T.; HAVENITH, M. G.; VISSER, R.; CLEUTJENS, J. P. Basement membranes in neoplasia. Prog. Histochem Cytochem., v. 24, n. 4, p. 1-92, 1992.

BOSMAN, F. T.; STAMENKOVIC, I. Functional structure and composition of the extracellular matrix. J. Pathol., v. 200, n. 4, p. 423-428, 2003.

BOWDEN, E. T.; BARTH, M.; THOMAS, D.; GLAZER, R. I.; MUELLER, S. C. An invasion-related complex of cortactin, paxillin and $\mathrm{PKCmu}$ associates with invadopodia at sites of extracellular matrix degradation. Oncogene, v. 18, n. 31, p. 4440-4449, 1999.

BRAR, S. S.; CORBIN, Z.; KENNEDY, T. P.; HEMENDINGER, R.; THORNTON, L.; BOMMARIUS, B.; ARNOLD, R. S.; WHORTON, A. R.; STURROCK, A. B.; HUECKSTEADT, T. P.; QUINN, M. T.; KRENITSKY, K.; ARDIE, K. G.; LAMBETH, J. D.; HOIDAL, J. R. NOX5 NAD(P)H oxidase regulates growth and apoptosis in DU 145 prostate cancer cells. Am. J. Physiol. Cell Physiol., v. 285, n. 2, p. C353-369, 2003.

BRIEGER, K.; SCHIAVONE, S.; MILLER, F. J., JR.; KRAUSE, K. H. Reactive oxygen species: from health to disease. Swiss Med. Wkly, v. 142, n., p. w13659, 2012.

BRYANT, C.; MENDENHALL, N. P.; HENDERSON, R. H.; NICHOLS, R. C.; MENDENHALL, W. M.; MORRIS, C. G.; WILLIAMS, C.; SU, Z.; LI, Z.; HOPPE, B. S. Does Race Influence Health-related Quality of Life and Toxicity Following Proton Therapy for Prostate Cancer? Am. J. Clin. Oncol., 2014. In press.

BRYCE, N. S.; CLARK, E. S.; LEYSATH, J. L.; CURRIE, J. D.; WEBB, D. J.; WEAVER, A. M. Cortactin promotes cell motility by enhancing lamellipodial persistence. Curr. Biol., v. 15, n. 14, p. 1276-1285, 2005.

BUCCIONE, R.; CALDIERI, G.; AYALA, I. Invadopodia: specialized tumor cell structures for the focal degradation of the extracellular matrix. Cancer Metastasis Rev., v. 28, n. 1-2, p. 137-149, 2009.

BUCCIONE, R.; ORTH, J. D.; MCNIVEN, M. A. Foot and mouth: podosomes, invadopodia and circular dorsal ruffles. Nat. Rev. Mol. Cell Biol., v. 5, n. 8, p. 647657, 2004.

BURGER, K. L.; LEARMAN, B. S.; BOUCHERLE, A. K.; SIRINTRAPUN, S. J.; ISOM, S.; DIAZ, B.; COURTNEIDGE, S. A.; SEALS, D. F. Src-dependent Tks5 phosphorylation regulates invadopodia-associated invasion in prostate cancer cells. Prostate, v. 74, n. 2, p. 134-148, 2014.

BURGESON, R. E.; CHIQUET, M.; DEUTZMANN, R.; EKBLOM, P.; ENGEL, J.; KLEINMAN, H.; MARTIN, G. R.; MENEGUZZI, G.; PAULSSON, M.; SANES, J.; ET AL. A new nomenclature for the laminins. Matrix Biol., v. 14, n. 3, p. 209-211, 1994. 
BUSCHMAN, M. D.; BROMANN, P. A.; CEJUDO-MARTIN, P.; WEN, F.; PASS, I.; COURTNEIDGE, S. A. The novel adaptor protein Tks4 (SH3PXD2B) is required for functional podosome formation. Molecular biology of the cell, v. 20, n. 5, p. 13021311, 2009.

CAPUANO, A. C.; JAEGER, R. G. The effect of laminin and its peptide SIKVAV on a human salivary gland myoepithelioma cell line. Oral Oncol., v. 40, n. 1, p. 36-42, 2004.

CARDOSO, S. V.; DO NASCIMENTO SOUZA, K. C.; DE FARIA, P. R.; LIMA, R. A.; NASCIMENTO, M. F.; EISENBERG, A. L.; DIAS, F. L.; LOYOLA, A. M. Warthin's tumor at the Brazilian National Cancer Institute: additional evidence of homogeneous sex prevalence and association with other neoplasms. ORL J. Otorhinolaryngol Relat. Spec., v. 70, n. 6, p. 339-343, 2008.

CASTRO, E.; EELES, R. The role of BRCA1 and BRCA2 in prostate cancer. Asian J. Androl., v. 14, n. 3, p. 409-414, 2012.

CHEN, W. T. Proteolytic activity of specialized surface protrusions formed at rosette contact sites of transformed cells. J. Exp. Zool., v. 251, n. 2, p. 167-185, 1989.

CHEN, W. T.; CHEN, J. M.; PARSONS, S. J.; PARSONS, J. T. Local degradation of fibronectin at sites of expression of the transforming gene product pp60src. Nature, v. 316, n. 6024, p. 156-158, 1985.

CHOI, Y. J.; KIM, J. K.; KIM, N.; KIM, K. W.; CHOI, E. K.; CHO, K. S. Functional MR imaging of prostate cancer. Radiographics, v. 27, n. 1, p. 63-75; discussion 75-67, 2007.

CHUN, T. H.; SABEH, F.; OTA, I.; MURPHY, H.; MCDONAGH, K. T.; HOLMBECK, K.; BIRKEDAL-HANSEN, H.; ALLEN, E. D.; WEISS, S. J. MT1-MMP-dependent neovessel formation within the confines of the three-dimensional extracellular matrix. J. Cell Biol., v. 167, n. 4, p. 757-767, 2004.

CLARK, E. S.; WEAVER, A. M. A new role for cortactin in invadopodia: regulation of protease secretion. Eur. J. Cell Biol., v. 87, n. 8-9, p. 581-590, 2008.

CLARK, E. S.; WHIGHAM, A. S.; YARBROUGH, W. G.; WEAVER, A. M. Cortactin is an essential regulator of matrix metalloproteinase secretion and extracellular matrix degradation in invadopodia. Cancer Res., v. 67, n. 9, p. 4227-4235, 2007.

COLOGNATO, H.; YURCHENCO, P. D. Form and function: the laminin family of heterotrimers. Dev. Dyn., v. 218, n. 2, p. 213-234, 2000.

COMOGLIO, P. M.; TRUSOLINO, L. Cancer: the matrix is now in control. Nat. Med., v. 11, n. 11, p. 1156-1159, 2005.

COURTNEIDGE, S. A. Cell migration and invasion in human disease: the Tks adaptor proteins. Biochem. Soc. Trans., v. 40, n. 1, p. 129-132, 2012. 
COURTNEIDGE, S. A.; AZUCENA, E. F.; PASS, I.; SEALS, D. F.; TESFAY, L. The SRC substrate Tks5, podosomes (invadopodia), and cancer cell invasion. Cold Spring Harb. Symp. Quant. Biol., v. 70, n., p. 167-171, 2005.

CRIMALDI, L.; COURTNEIDGE, S. A.; GIMONA, M. Tks5 recruits AFAP-110, p190RhoGAP, and cortactin for podosome formation. Experimental cell research, v. 315, n. 15, p. 2581-2592, 2009.

CROCETTI, E.; DE ANGELIS, R.; BUZZONI, C.; MARIOTTO, A.; STORM, H.; COLONNA, M.; ZANETTI, R.; SERRAINO, D.; MICHIARA, M.; CIRILLI, C.; IANNELLI, A.; MAZZOLENI, G.; SECHI, O.; SANOJA GONZALEZ, M. E.; GUZZINATI, S.; CAPOCACCIA, R.; DAL MASO, L.; GROUP, A. W. Cancer prevalence in United States, Nordic Countries, Italy, Australia, and France: an analysis of geographic variability. Br. J. Cancer, v. 109, n. 1, p. 219-228, 2013.

D'AUTREAUX, B.; TOLEDANO, M. B. ROS as signalling molecules: mechanisms that generate specificity in ROS homeostasis. Nat. Rev. Mol. Cell Biol., v. 8, n. 10, p. 813-824, 2007.

DALEY, W. P.; PETERS, S. B.; LARSEN, M. Extracellular matrix dynamics in development and regenerative medicine. J. Cell Sci., v. 121, n. Pt 3, p. 255-264, 2008.

DAVID-PFEUTY, T.; SINGER, S. J. Altered distributions of the cytoskeletal proteins vinculin and alpha-actinin in cultured fibroblasts transformed by Rous sarcoma virus.

Proc. Natl. Acad. Sci. U S A, v. 77, n. 11, p. 6687-6691, 1980.

DAVIS, G. E.; BAYLESS, K. J.; DAVIS, M. J.; MEININGER, G. A. Regulation of tissue injury responses by the exposure of matricryptic sites within extracellular matrix molecules. Am.J Pathol, v. 156, n. 5, p. 1489-1498, 2000.

DELAHUNT, B.; MILLER, R. J.; SRIGLEY, J. R.; EVANS, A. J.; SAMARATUNGA, H. Gleason grading: past, present and future. Histopathology, v. 60, n. 1, p. 75-86, 2012.

DEMICHELIS, F.; STANFORD, J. L. Genetic predisposition to prostate cancer: Update and future perspectives. Urol. Oncol., v., n., p., 2014.

DESAI, B.; MA, T.; CHELLAIAH, M. A. Invadopodia and matrix degradation, a new property of prostate cancer cells during migration and invasion. J. Biol. Chem., v. 283, n. 20, p. 13856-13866, 2008.

DESTAING, O.; SANJAY, A.; ITZSTEIN, C.; HORNE, W. C.; TOOMRE, D.; DE CAMILLI, P.; BARON, R. The tyrosine kinase activity of $\mathrm{c}$-Src regulates actin dynamics and organization of podosomes in osteoclasts. Molecular biology of the cell, v. 19, n. 1, p. 394-404, 2008. 
DIAMANDIS, E. P.; YOUSEF, G. M. Human tissue kallikrein gene family: a rich source of novel disease biomarkers. Expert Rev. Mol. Diagn., v. 1, n. 2, p. 182-190, 2001.

DIAZ, B.; SHANI, G.; PASS, I.; ANDERSON, D.; QUINTAVALLE, M.; COURTNEIDGE, S. A. Tks5-dependent, nox-mediated generation of reactive oxygen species is necessary for invadopodia formation. Sci. Signal., v. 2, n. 88, p. ra53, 2009.

EDWARDS, D. R. The cancer degradome : proteases and cancer biology. ed. New York, NY: Springer, 2008.

EDWARDS, S. M.; EELES, R. A. Unravelling the genetics of prostate cancer. Am. J. Med. Genet. C. Semin. Med. Genet., v. 129C, n. 1, p. 65-73, 2004.

EKBLOM, M.; FALK, M.; SALMIVIRTA, K.; DURBEEJ, M.; EKBLOM, P. Laminin isoforms and epithelial development. Ann. N. Y. Acad. Sci., v. 857, n., p. 194-211, 1998a.

EKBLOM, M.; FALK, M.; SALMIVIRTA, K.; DURBEEJ, M.; EKBLOM, P. Laminin isoforms and epithelial development. Ann. N. Y. Acad. Sci., v. 857, n., p. 194-211, $1998 b$.

EKBLOM, P. Receptors for laminins during epithelial morphogenesis. Curr. Opin. Cell Biol., v. 8, n. 5, p. 700-706, 1996.

EKBLOM, P.; TIMPL, R. Cell-to-cell contact and extracellular matrix. A multifaceted approach emerging. Curr. Opin. Cell Biol., v. 8, n. 5, p. 599-601, 1996.

ELLEM, S. J.; DE-JUAN-PARDO, E. M.; RISBRIDGER, G. P. In vitro modeling of the prostate cancer microenvironment. Adv. Drug Deliv. Rev., v., n., p., 2014.

ELSHAFEI, A.; KARTHA, G.; LI, Y.; A, S. M.; HATEM, A.; GAO, T.; JONES, J. S. Low risk patients benefit from extreme anterior apical sampling on initial biopsy for prostate cancer diagnosis. Prostate, v. 74, n. 12, p. 1183-1188, 2014.

EPSTEIN, J. I.; PARTIN, A. W.; SAUVAGEOT, J.; WALSH, P. C. Prediction of progression following radical prostatectomy. A multivariate analysis of 721 men with long-term follow-up. Am. J. Surg. Pathol., v. 20, n. 3, p. 286-292, 1996.

EPSTEIN, J. I.; SANDERSON, H.; CARTER, H. B.; SCHARFSTEIN, D. O. Utility of saturation biopsy to predict insignificant cancer at radical prostatectomy. Urology, $\mathrm{v}$. 66, n. 2, p. 356-360, 2005.

FAISAL KHAN, K. M.; LAURIE, G. W.; MCCAFFREY, T. A.; FALCONE, D. J. Exposure of cryptic domains in the alpha 1-chain of laminin-1 by elastase stimulates macrophages urokinase and matrix metalloproteinase-9 expression. J. Biol. Chem., v. 277, n. 16, p. 13778-13786, 2002. 
FARIA, E. F.; CARVALHAL, G. F.; DOS REIS, R. B.; TOBIAS-MACHADO, M.; VIEIRA, R. A.; REIS, L. O.; NOGUEIRA, L.; MACHADO, R. D.; FREITAS, C. H., JR.; MAGNABOSCO, W. J.; MAUAD, E. C.; CARVALHO, A. L. Use of low free to total PSA ratio in prostate cancer screening: detection rates, clinical and pathological findings in Brazilian men with serum PSA levels $<4.0 \mathrm{ng} / \mathrm{mL}$. BJU Int., v. $110, \mathrm{n} .11$ Pt B, p. E653-657, 2012.

FEKETE, A.; BOGEL, G.; PESTI, S.; PETERFI, Z.; GEISZT, M.; BUDAY, L. EGF regulates tyrosine phosphorylation and membrane-translocation of the scaffold protein Tks5. J. Mol. Signal., v. 8, n., p. 8, 2013.

FIANDALO, M. V.; WILTON, J.; MOHLER, J. L. Roles for the Backdoor Pathway of Androgen Metabolism in Prostate Cancer Response to Castration and Drug Treatment. Int. J. Biol. Sci., v. 10, n. 6, p. 596-601, 2014.

FIDLER, I. J. The pathogenesis of cancer metastasis: the 'seed and soil' hypothesis revisited. Nat. Rev. Cancer, v. 3, n. 6, p. 453-458, 2003.

FRANTZ, C.; STEWART, K. M.; WEAVER, V. M. The extracellular matrix at a glance. J. Cell Sci., v. 123, n. Pt 24, p. 4195-4200, 2010.

FREITAS, V. M.; JAEGER, R. G. The effect of laminin and its peptide SIKVAV on a human salivary gland adenoid cystic carcinoma cell line. Virchows Arch., v. 441, n. 6, p. 569-576, 2002.

FREITAS, V. M.; SCHEREMETA, B.; HOFFMAN, M. P.; JAEGER, R. G. Laminin-1 and SIKVAV a laminin-1-derived peptide, regulate the morphology and protease activity of a human salivary gland adenoid cystic carcinoma cell line. Oral Oncol., v. 40, n. 5, p. 483-489, 2004.

FREITAS, V. M.; VILAS-BOAS, V. F.; PIMENTA, D. C.; LOUREIRO, V.; JULIANO, M. A.; CARVALHO, M. R.; PINHEIRO, J. J.; CAMARGO, A. C.; MORISCOT, A. S.; HOFFMAN, M. P.; JAEGER, R. G. SIKVAV, a laminin alpha1-derived peptide, interacts with integrins and increases protease activity of a human salivary gland adenoid cystic carcinoma cell line through the ERK 1/2 signaling pathway. Am. J. Pathol., v. 171, n. 1, p. 124-138, 2007.

FRIDMAN, R.; GIACCONE, G.; KANEMOTO, T.; MARTIN, G. R.; GAZDAR, A. F.; MULSHINE, J. L. Reconstituted basement membrane (matrigel) and laminin can enhance the tumorigenicity and the drug resistance of small cell lung cancer cell lines. Proc. Natl. Acad. Sci. U S A, v. 87, n. 17, p. 6698-6702, 1990.

FRITZ, V.; BENFODDA, Z.; HENRIQUET, C.; HURE, S.; CRISTOL, J. P.; MICHEL, F.; CARBONNEAU, M. A.; CASAS, F.; FAJAS, L. Metabolic intervention on lipid synthesis converging pathways abrogates prostate cancer growth. Oncogene, v. 32, n. 42, p. 5101-5110, 2013.

GAMA-DE-SOUZA, L. N.; CYRENO-OLIVEIRA, E.; FREITAS, V. M.; MELO, E. S.; VILAS-BOAS, V. F.; MORISCOT, A. S.; JAEGER, R. G. Adhesion and protease activity in cell lines from human salivary gland tumors are regulated by the laminin- 
derived peptide AG73, syndecan-1 and beta1 integrin. Matrix Biol., v. 27, n. 5, p. 402-419, 2008.

GHAFOORI, M.; ALAVI, M.; ALIYARI GHASABEH, M. MRI in prostate cancer. Iran. Red. Crescent Med. J., v. 15, n. 12, p. e16620, 2013.

GHOSH, S.; STACK, M. S. Proteolytic modification of laminins: functional consequences. Microsc. Res. Tech., v. 51, n. 3, p. 238-246, 2000.

GIANNI, D.; DIAZ, B.; TAULET, N.; FOWLER, B.; COURTNEIDGE, S. A.; BOKOCH, G. M. Novel p47(phox)-related organizers regulate localized NADPH oxidase 1 (Nox1) activity. Sci. Signal., v. 2, n. 88, p. ra54, 2009.

GIMONA, M.; BUCCIONE, R.; COURTNEIDGE, S. A.; LINDER, S. Assembly and biological role of podosomes and invadopodia. Curr. Opin. Cell Biol., v. 20, n. 2, p. 235-241, 2008.

GINSBURG, S. B.; VISWANATH, S. E.; BLOCH, B. N.; ROFSKY, N. M.; GENEGA, E. M.; LENKINSKI, R. E.; MADABHUSHI, A. Novel PCA-VIP scheme for ranking MRI protocols and identifying computer-extracted MRI measurements associated with central gland and peripheral zone prostate tumors. J. Magn. Reson. Imaging, v., n., p., 2014.

GIVANT-HORWITZ, V.; DAVIDSON, B.; REICH, R. Laminin-induced signaling in tumor cells. Cancer Lett., v. 223, n. 1, p. 1-10, 2005.

GOMELLA, L. G.; LIU, X. S.; TRABULSI, E. J.; KELLY, W. K.; MYERS, R.; SHOWALTER, T.; DICKER, A.; WENDER, R. Screening for prostate cancer: the current evidence and guidelines controversy. Can. J. Urol., v. 18, n. 5, p. 5875-5883, 2011.

GONG, Y.; CHIPPADA-VENKATA, U. D.; OH, W. K. Roles of matrix metalloproteinases and their natural inhibitors in prostate cancer progression. Cancers (Basel), v. 6, n. 3, p. 1298-1327, 2014.

GRANT, D. S.; KINSELLA, J. L.; FRIDMAN, R.; AUERBACH, R.; PIASECKI, B. A.; YAMADA, Y.; ZAIN, M.; KLEINMAN, H. K. Interaction of endothelial cells with a laminin A chain peptide (SIKVAV) in vitro and induction of angiogenic behavior in vivo. J. Cell Physiol., v. 153, n. 3, p. 614-625, 1992.

GRUNERT, S.; JECHLINGER, M.; BEUG, H. Diverse cellular and molecular mechanisms contribute to epithelial plasticity and metastasis. Nat. Rev. Mo.I Cell Biol., v. 4, n. 8, p. 657-665, 2003.

GUARINO, M. Src signaling in cancer invasion. J. Cell Physiol., v. 223, n. 1, p. 1426, 2010.

GUDJONSSON, T.; RONNOV-JESSEN, L.; VILLADSEN, R.; RANK, F.; BISSELL, M. J.; PETERSEN, O. W. Normal and tumor-derived myoepithelial cells differ in their 
ability to interact with luminal breast epithelial cells for polarity and basement membrane deposition. J. Cel.I Sci., v. 115, n. Pt 1, p. 39-50, 2002.

HAMELIN-PEYRON, C.; VLAEMINCK-GUILLEM, V.; HAIDOUS, H.; SCHWALL, G. P.; POZNANOVIC, S.; GORIUS-GALLET, E.; MICHEL, S.; LARUE, A.; GUILLOTTE, M.; RUFFION, A.; CHOQUET-KASTYLEVSKY, G.; ATAMAN-ONAL, Y. Prostate cancer biomarker annexin $\mathrm{A} 3$ detected in urines obtained following digital rectal examination presents antigenic variability. Clin. Biochem., v. 47, n. 10-11, p. 901908, 2014.

HANDSLEY, M. M.; EDWARDS, D. R. Metalloproteinases and their inhibitors in tumor angiogenesis. Int. J. Cancer., v. 115, n. 6, p. 849-860, 2005.

HELFAND, B. T.; CATALONA, W. J. The epidemiology and clinical implications of genetic variation in prostate cancer. Urol. Clin. North Am., v. 41, n. 2, p. 277-297, 2014.

HONG, S. K.; OH, J. J.; BYUN, S. S.; HWANG, S. I.; CHOO, M. S.; LEE, S. E. Value of prostate-specific antigen (PSA) mass ratio in the detection of prostate cancer in men with PSA levels of </=10 ng/mL. BJU Int., v. 110, n. 2 Pt 2, p. E81-85, 2012.

HUMPHREY, P. A. Gleason pattern 5 adenocarcinoma in prostate needle biopsy. J. Urol., v. 188, n. 4, p. 1341-1342, 2012a.

HUMPHREY, P. A. Minimal adenocarcinoma on prostate needle biopsy and falsenegative diagnosis of malignancy. J. Urol., v. 187, n. 1, p. 283-284, 2012b.

HYNES, R. O. The extracellular matrix: not just pretty fibrils. Science, v. 326, n. 5957, p. 1216-1219, 2009.

INSTITUTO NACIONAL DO CÂNCER. Estimativa 2014: incidência de câncer no Brasil. Rio de Janeiro: Ministério da Saúde, 2014.

IRELLI, A.; BRUERA, G.; CANNITA, K.; PALLUZZI, E.; GRAVINA, G. L.; FESTUCCIA, C.; FICORELLA, C.; RICEVUTO, E. Bioclinical Parameters Driving Decision-Making of Subsequent Lines of Treatment in Metastatic CastrationResistant Prostate Cancer. Biomed. Res. Int., v. 2014, n., p. 909623, 2014.

ISAACS, W. B. Inherited susceptibility for aggressive prostate cancer. Asian J. Androl., v. 14, n. 3, p. 415-418, 2012.

IWAMOTO, Y.; ROBEY, F. A.; GRAF, J.; SASAKI, M.; KLEINMAN, H. K.; YAMADA, Y.; MARTIN, G. R. YIGSR, a synthetic laminin pentapeptide, inhibits experimental metastasis formation. Science, v. 238, n. 4830, p. 1132-1134, 1987.

KADLER, K. E.; HOLMES, D. F.; TROTTER, J. A.; CHAPMAN, J. A. Collagen fibril formation. Biochem. J., v. 316 ( Pt 1), n., p. 1-11, 1996. 
KAHN, B.; COLLAZO, J.; KYPRIANOU, N. Androgen Receptor as a Driver of Therapeutic Resistance in Advanced Prostate Cancer. Int. J. Biol. Sci., v. 10, n. 6, p. 588-595, 2014.

KANEMOTO, T.; REICH, R.; ROYCE, L.; GREATOREX, D.; ADLER, S. H.; SHIRAISHI, N.; MARTIN, G. R.; YAMADA, Y.; KLEINMAN, H. K. Identification of an amino acid sequence from the laminin $A$ chain that stimulates metastasis and collagenase IV production. Proc. Natl. Acad. Sci. U S A, v. 87, n. 6, p. 2279-2283, 1990.

KELLEY, L. C.; AMMER, A. G.; HAYES, K. E.; MARTIN, K. H.; MACHIDA, K.; JIA, L.; MAYER, B. J.; WEED, S. A. Oncogenic Src requires a wild-type counterpart to regulate invadopodia maturation. J. Cell Sci., v. 123, n. Pt 22, p. 3923-3932, 2010.

KELLY, T.; MUELLER, S. C.; YEH, Y.; CHEN, W. T. Invadopodia promote proteolysis of a wide variety of extracellular matrix proteins. J. Cell Physiol., v. 158, n. 2, p. 299308, 1994.

KESSENBROCK, K.; PLAKS, V.; WERB, Z. Matrix metalloproteinases: regulators of the tumor microenvironment. Cell, v. 141, n. 1, p. 52-67, 2010.

KNOX, J. D.; CRESS, A. E.; CLARK, V.; MANRIQUEZ, L.; AFFINITO, K. S.; DALKIN, B. L.; NAGLE, R. B. Differential expression of extracellular matrix molecules and the alpha 6-integrins in the normal and neoplastic prostate. Am. J. Pathol., v. 145, n. 1, p. 167-174, 1994.

KOOCHEKPOUR, S. Biological and clinical significance of androgens and androgen receptor in prostate cancer. Int. J. Biol. Sci., v. 10, n. 6, p. 652-653, 2014.

KOUTROS, S.; BEANE FREEMAN, L. E.; LUBIN, J. H.; HELTSHE, S. L.; ANDREOTTI, G.; BARRY, K. H.; DELLAVALLE, C. T.; HOPPIN, J. A.; SANDLER, D. P.; LYNCH, C. F.; BLAIR, A.; ALAVANJA, M. C. Risk of total and aggressive prostate cancer and pesticide use in the Agricultural Health Study. Am. J. Epidemiol., v. 177, n. 1, p. 59-74, $2013 a$.

KOUTROS, S.; BERNDT, S. I.; HUGHES BARRY, K.; ANDREOTTI, G.; HOPPIN, J. A.; SANDLER, D. P.; YEAGER, M.; BURDETT, L. A.; YUENGER, J.; ALAVANJA, M. C.; BEANE FREEMAN, L. E. Genetic susceptibility loci, pesticide exposure and prostate cancer risk. PLoS One, v. 8, n. 4, p. e58195, 2013b.

KURATOMI, Y.; NOMIZU, M.; TANAKA, K.; PONCE, M. L.; KOMIYAMA, S.; KLEINMAN, H. K.; YAMADA, Y. Laminin gamma 1 chain peptide, C-16 (KAFDITYVRLKF), promotes migration, MMP-9 secretion, and pulmonary metastasis of B16-F10 mouse melanoma cells. Br. J. Cancer, v. 86, n. 7, p. 1169-1173, 2002.

LI, X. Y.; OTA, I.; YANA, I.; SABEH, F.; WEISS, S. J. Molecular dissection of the structural machinery underlying the tissue-invasive activity of membrane type-1 matrix metalloproteinase. Molecular biology of the cell, v. 19, n. 8, p. 3221-3233, 2008. 
LILJA, H. A kallikrein-like serine protease in prostatic fluid cleaves the predominant seminal vesicle protein. J. Clin. Invest., v. 76, n. 5, p. 1899-1903, 1985.

LINDER, S. The matrix corroded: podosomes and invadopodia in extracellular matrix degradation. Trends Cell Biol. v. 17, n. 3, p. 107-117, 2007.

LITTLEPAGE, L. E.; STERNLICHT, M. D.; ROUGIER, N.; PHILLIPS, J.; GALLO, E.; YU, Y.; WILLIAMS, K.; BRENOT, A.; GORDON, J. I.; WERB, Z. Matrix metalloproteinases contribute distinct roles in neuroendocrine prostate carcinogenesis, metastasis, and angiogenesis progression. Cancer Res, v. 70, n. 6 , p. 2224-2234, 2010.

LOCK, P.; ABRAM, C. L.; GIBSON, T.; COURTNEIDGE, S. A. A new method for isolating tyrosine kinase substrates used to identify fish, an $\mathrm{SH} 3$ and PX domaincontaining protein, and Src substrate. EMBO J., v. 17, n. 15, p. 4346-4357, 1998.

LU, P.; WEAVER, V. M.; WERB, Z. The extracellular matrix: a dynamic niche in cancer progression. J. Cell Biol., v. 196, n. 4, p. 395-406, 2012.

LUCIANI, L. G.; DE GIORGI, G.; VALOTTO, C.; ZANIN, M.; BIERTI, S.; ZATTONI, F. Role of transperineal six-core prostate biopsy in patients with prostate-specific antigen level greater than $10 \mathrm{ng} / \mathrm{mL}$ and abnormal digital rectal examination findings. Urology, v. 67, n. 3, p. 555-558, 2006.

LUKASHEV, M. E.; WERB, Z. ECM signalling: orchestrating cell behaviour and misbehaviour. Trends Cell Biol., v. 8, n. 11, p. 437-441, 1998.

MALINDA, K. M.; KLEINMAN, H. K. The laminins. Int. J. Biochem. Cell Biol., v. 28, n. 9, p. 957-959, 1996.

MANDAIR, D.; ROSSI, R. E.; PERICLEOUS, M.; WHYAND, T.; CAPLIN, M. E. Prostate cancer and the influence of dietary factors and supplements: a systematic review. Nutr. Metab. (Lond), v. 11, n., p. 30, 2014.

MAO, Y.; SCHWARZBAUER, J. E. Fibronectin fibrillogenesis, a cell-mediated matrix assembly process. Matrix Biol., v. 24, n. 6, p. 389-399, 2005.

MARASTONI, S.; LIGRESTI, G.; LORENZON, E.; COLOMBATTI, A.; MONGIAT, M. Extracellular matrix: a matter of life and death. Connect. Tissue Res., v. 49, n. 3, p. 203-206, 2008.

MARCHISIO, P. C.; CIRILLO, D.; NALDINI, L.; PRIMAVERA, M. V.; TETI, A.; ZAMBONIN-ZALLONE, A. Cell-substratum interaction of cultured avian osteoclasts is mediated by specific adhesion structures. J. Cell Biol., v. 99, n. 5, p. 1696-1705, 1984.

MARTIN, G. R.; TIMPL, R. Laminin and other basement membrane components. Annu. Rev. Cell Biol., v. 3, n., p. 57-85, 1987. 
MEHROTRA, R.; YADAV, S. Oral squamous cell carcinoma: etiology, pathogenesis and prognostic value of genomic alterations. Indian J. Cancer, v. 43, n. 2, p. 60-66, 2006.

MILECKI, T.; ANTCZAK, A.; KWIAS, Z.; MILECKI, P. The use of luteinizing hormonereleasing hormone analogues is still an indispensable element of therapy in castrateresistant prostate cancer. Contemp. Oncol. (Pozn), v. 18, n. 2, p. 85-89, 2014.

MILES, F. L.; SIKES, R. A. Insidious Changes in Stromal Matrix Fuel Cancer Progression. Mol. Cancer Res., v., n., p., 2014.

MINER, J. H.; YURCHENCO, P. D. Laminin functions in tissue morphogenesis. Annu. Rev. Cell Dev. Biol., v. 20, n., p. 255-284, $2004 a$.

MINER, J. H.; YURCHENCO, P. D. Laminin functions in tissue morphogenesis. Annu. Rev. Cell Dev. Biol., v. 20, n., p. 255-284, 2004b.

MONSKY, W. L.; CHEN, W. T. Proteases of cell adhesion proteins in cancer. Semin. Cancer Biol., v. 4, n. 4, p. 251-258, 1993.

MOSTAGHEL, E. A.; NELSON, P. S.; LANGE, P.; LIN, D. W.; TAPLIN, M. E.; BALK, S.; ELLIS, W.; KANTOFF, P.; MARCK, B.; TAMAE, D.; MATSUMOTO, A. M.; TRUE, L. D.; VESSELLA, R.; PENNING, T.; HUNTER MERRILL, R.; GULATI, R.; MONTGOMERY, B. Targeted androgen pathway suppression in localized prostate cancer: a pilot study. J. Clin. Oncol., v. 32, n. 3, p. 229-237, 2014.

MOTT, J. D.; WERB, Z. Regulation of matrix biology by matrix metalloproteinases. Curr. Opin. Cell Biol., v. 16, n. 5, p. 558-564, 2004.

MURASHIMA, A.; KISHIGAMI, S.; THOMSON, A.; YAMADA, G. Androgens and mammalian male reproductive tract development. Biochim. Biophys Acta, v., n., p., 2014.

MURPHY, D. A.; COURTNEIDGE, S. A. The 'ins' and 'outs' of podosomes and invadopodia: characteristics, formation and function. Nat. Rev. Mol. Cell Biol., v. 12, n. 7, p. 413-426, 2011.

NAKAGAWA, $\mathrm{H}$. [Prostate cancer biomarker search by genome analysis]. Nihon. Rinsho., v. 69 Suppl 5, n., p. 145-149, 2011.

NASCIMENTO, C. F.; DE SIQUEIRA, A. S.; PINHEIRO, J. J.; FREITAS, V. M.; JAEGER, R. G. Laminin-111 derived peptides AG73 and C16 regulate invadopodia activity of a human adenoid cystic carcinoma cell line. Experimental cell research, v. 317, n. 18, p. 2562-2572, 2011.

NASKAR, S.; KUNDU, S. K.; BHATTACHARYYA, N. K.; BHATTACHARYYA, P. K.; KUNDU, A. K. A study to correlate histopathology, biochemical marker and immunohistochemical expression of sex-steroid receptors in prostatic growth. Indian J. Med. Paediatr. Oncol., v. 35, n. 1, p. 40-43, 2014. 
NOMIZU, M.; KURATOMI, Y.; PONCE, M. L.; SONG, S. Y.; MIYOSHI, K.; OTAKA, A.; POWELL, S. K.; HOFFMAN, M. P.; KLEINMAN, H. K.; YAMADA, Y. Cell adhesive sequences in mouse laminin beta1 chain. Arch. Biochem. Biophys, v. 378, n. 2, p. 311-320, 2000.

NOMIZU, M.; KURATOMI, Y.; SONG, S. Y.; PONCE, M. L.; HOFFMAN, M. P.; POWELL, S. K.; MIYOSHI, K.; OTAKA, A.; KLEINMAN, H. K.; YAMADA, Y. Identification of cell binding sequences in mouse laminin gamma1 chain by systematic peptide screening. J. Biol. Chem., v. 272, n. 51, p. 32198-32205, 1997.

NOMIZU, M.; YOKOYAMA, F.; SUZUKI, N.; OKAZAKI, I.; NISHI, N.; PONCE, M. L.; KLEINMAN, H. K.; YAMAMOTO, Y.; NAKAGAWA, S.; MAYUMI, T. Identification of homologous biologically active sites on the $\mathrm{N}$-terminal domain of laminin alpha chains. Biochemistry, v. 40, n. 50, p. 15310-15317, 2001.

NURNBERG, A.; KITZING, T.; GROSSE, R. Nucleating actin for invasion. Nat. Rev. Cancer, v. 11, n. 3, p. 177-187, 2011.

OHUCHI, E.; IMAI, K.; FUJII, Y.; SATO, H.; SEIKI, M.; OKADA, Y. Membrane type 1 matrix metalloproteinase digests interstitial collagens and other extracellular matrix macromolecules. J. Biol. Chem., v. 272, n. 4, p. 2446-2451, 1997.

OIKAWA, T.; ITOH, T.; TAKENAWA, T. Sequential signals toward podosome formation in NIH-src cells. J. Cell Biol., v. 182, n. 1, p. 157-169, 2008.

OIKAWA, Y.; HANSSON, J.; SASAKI, T.; ROUSSELLE, P.; DOMOGATSKAYA, A.; RODIN, S.; TRYGGVASON, K.; PATARROYO, M. Melanoma cells produce multiple laminin isoforms and strongly migrate on alpha5 laminin(s) via several integrin receptors. Experimental cell research, v. 317, n. 8, p. 1119-1133, 2011.

ORGANIZAÇÃO MUNDIAL DA SAÚDE. The global burden of disease, 2013.

OSER, M.; YAMAGUCHI, H.; MADER, C. C.; BRAVO-CORDERO, J. J.; ARIAS, M.; CHEN, X.; DESMARAIS, V.; VAN RHEENEN, J.; KOLESKE, A. J.; CONDEELIS, J. Cortactin regulates cofilin and N-WASp activities to control the stages of invadopodium assembly and maturation. J. Cell Biol., v. 186, n. 4, p. 571-587, 2009.

OVERALL, C. M.; BLOBEL, C. P. In search of partners: linking extracellular proteases to substrates. Nat. Rev. Mol. Cell Biol., v. 8, n. 3, p. 245-257, 2007.

PAGE-MCCAW, A.; EWALD, A. J.; WERB, Z. Matrix metalloproteinases and the regulation of tissue remodelling. Nat. Rev. Mol. Cell Biol., v. 8, n. 3, p. 221-233, 2007.

PATARROYO, M.; TRYGGVASON, K.; VIRTANEN, I. Laminin isoforms in tumor invasion, angiogenesis and metastasis. Semin. Cancer. Biol., v. 12, n. 3, p. $197-$ 207, 2002. 
PONCE, M. L.; KLEINMAN, H. K. Identification of redundant angiogenic sites in laminin alpha1 and gamma1 chains. Experimental cell research, v. 285, n. 2, p. 189-195, 2003.

PONCE, M. L.; NOMIZU, M.; KLEINMAN, H. K. An angiogenic laminin site and its antagonist bind through the alpha(v)beta3 and alpha5beta1 integrins. Faseb J., v. 15, n. 8, p. 1389-1397, 2001.

POWELL, S. K.; KLEINMAN, H. K. Neuronal laminins and their cellular receptors. Int. J. Biochem Cell Biol., v. 29, n. 3, p. 401-414, 1997.

REESE, A. C.; COWAN, J. E.; BRAJTBORD, J. S.; HARRIS, C. R.; CARROLL, P. R.; COOPERBERG, M. R. The quantitative Gleason score improves prostate cancer risk assessment. Cancer, v. 118, n. 24, p. 6046-6054, 2012.

ROWE, R. G.; WEISS, S. J. Navigating ECM barriers at the invasive front: the cancer cell-stroma interface. Annu. Rev. Cell. Dev. Biol., v. 25, n., p. 567-595, 2009.

RUFFELL, B.; AU, A.; RUGO, H. S.; ESSERMAN, L. J.; HWANG, E. S.; COUSSENS, L. M. Leukocyte composition of human breast cancer. Proc. Natl. Acad. Sci. U S A, v. 109, n. 8, p. 2796-2801, 2012.

SABEH, F.; LI, X. Y.; SAUNDERS, T. L.; ROWE, R. G.; WEISS, S. J. Secreted versus membrane-anchored collagenases: relative roles in fibroblast-dependent collagenolysis and invasion. J. Biol. Chem., v. 284, n. 34, p. 23001-23011, 2009.

SABEH, F.; OTA, I.; HOLMBECK, K.; BIRKEDAL-HANSEN, H.; SOLOWAY, P.; BALBIN, M.; LOPEZ-OTIN, C.; SHAPIRO, S.; INADA, M.; KRANE, S.; ALLEN, E.; CHUNG, D.; WEISS, S. J. Tumor cell traffic through the extracellular matrix is controlled by the membrane-anchored collagenase MT1-MMP. J. Cell Biol., v. 167, n. 4, p. 769-781, 2004.

SASAKI, T.; FASSLER, R.; HOHENESTER, E. Laminin: the crux of basement membrane assembly. J. Cell Biol., v. 164, n. 7, p. 959-963, 2004.

SCHENK, S.; QUARANTA, V. Tales from the crypt[ic] sites of the extracellular matrix. Trends Cell Biol., v. 13, n. 7, p. 366-375, 2003.

SCHRODER, F. H. Landmarks in prostate cancer screening. BJU Int., v. 110 Suppl 1, n., p. 3-7, 2012.

SEALS, D. F.; AZUCENA, E. F., JR.; PASS, I.; TESFAY, L.; GORDON, R.; WOODROW, M.; RESAU, J. H.; COURTNEIDGE, S. A. The adaptor protein Tks5/Fish is required for podosome formation and function, and for the proteasedriven invasion of cancer cells. Cancer Cell, v. 7, n. 2, p. 155-165, 2005.

SHARMA, V. P.; EDDY, R.; ENTENBERG, D.; KAI, M.; GERTLER, F. B.; CONDEELIS, J. Tks5 and SHIP2 regulate invadopodium maturation, but not initiation, in breast carcinoma cells. Curr. Biol., v. 23, n. 21, p. 2079-2089, 2013. 
SIBONY-BENYAMINI, H.; GIL-HENN, H. Invadopodia: the leading force. Eur. J. Cell Biol., v. 91, n. 11-12, p. 896-901, 2012.

SIQUEIRA, A. S.; GAMA-DE-SOUZA, L. N.; ARNAUD, M. V.; PINHEIRO, J. J.; JAEGER, R. G. Laminin-derived peptide AG73 regulates migration, invasion, and protease activity of human oral squamous cell carcinoma cells through syndecan-1 and beta1 integrin. Tumour Biol., v. 31, n. 1, p. 46-58, 2010.

SIQUEIRA, A. S.; Peptídeo C16, derivado da laminina, regula invasão, dinâmica de formação e atividade de invadopódios em linhagens celulares de carcinoma epidermóide e fibrossarcoma. 2014.110 f. Tese (Doutorado em Biologia Celular e Tecidual) - Instituto de Ciências Biomédicas, Universidade de São Paulo, São Paulo, 2014.

SOUNNI, N. E.; BARAMOVA, E. N.; MUNAUT, C.; MAQUOI, E.; FRANKENNE, F.; FOIDART, J. M.; NOEL, A. Expression of membrane type 1 matrix metalloproteinase (MT1-MMP) in A2058 melanoma cells is associated with MMP-2 activation and increased tumor growth and vascularization. Int. J. Cancer., v. 98, n. 1, p. 23-28, 2002.

STANGELBERGER, A.; SCHALLY, A. V.; DJAVAN, B. New treatment approaches for prostate cancer based on peptide analogues. Eur. Urol., v. 53, n. 5, p. 890-900, 2008

STANGELBERGER, A.; WALDERT, M.; DJAVAN, B. Prostate cancer in elderly men. Rev. Urol., v. 10, n. 2, p. 111-119, 2008.

STERNLICHT, M. D.; WERB, Z. How matrix metalloproteinases regulate cell behavior. Annu. Rev. Cell Dev. Biol., v. 17, n., p. 463-516, 2001.

STEUBER, T.; O'BRIEN, M. F.; LILJA, H. Serum markers for prostate cancer: a rational approach to the literature. Eur. Urol., v. 54, n. 1, p. 31-40, 2008.

STEWART, D. A.; COOPER, C. R.; SIKES, R. A. Changes in extracellular matrix $(E C M)$ and $E C M$-associated proteins in the metastatic progression of prostate cancer. Reprod. Biol. Endocrinol., v. 2, n., p. 2, 2004.

STYLLI, S. S.; KAYE, A. H.; LOCK, P. Invadopodia: at the cutting edge of tumour invasion. J. Clin. Neurosci., v. 15, n. 7, p. 725-737, 2008.

TAMMI, M. I.; DAY, A. J.; TURLEY, E. A. Hyaluronan and homeostasis: a balancing act. J. Biol. Chem., v. 277, n. 7, p. 4581-4584, 2002.

TANZER, M. L. Current concepts of extracellular matrix. J. Orthop. Sci., v. 11, n. 3, p. 326-331, 2006.

TARONE, G.; CIRILLO, D.; GIANCOTTI, F. G.; COMOGLIO, P. M.; MARCHISIO, P. C. Rous sarcoma virus-transformed fibroblasts adhere primarily at discrete protrusions of the ventral membrane called podosomes. Experimental cell research, v. 159, n. 1, p. 141-157, 1985. 
TERRANOVA, V. P.; WILLIAMS, J. E.; LIOTTA, L. A.; MARTIN, G. R. Modulation of the metastatic activity of melanoma cells by laminin and fibronectin. Science, v. 226, n. 4677, p. 982-985, 1984.

THOMAS, S. M.; BRUGGE, J. S. Cellular functions regulated by Src family kinases. Annu. Rev. Cell Dev. Biol., v. 13, n., p. 513-609, 1997.

TIMPL, R.; BROWN, J. C. The laminins. Matrix Biol., v. 14, n. 4, p. 275-281, 1994.

TIMPL, R.; ROHDE, H.; ROBEY, P. G.; RENNARD, S. I.; FOIDART, J. M.; MARTIN, G. R. Laminin--a glycoprotein from basement membranes. J. Biol. Chem., v. 254, n. 19, p. 9933-9937, 1979.

WARIS, G.; AHSAN, H. Reactive oxygen species: role in the development of cancer and various chronic conditions. J. Carcinog., v. 5, n., p. 14, 2006.

WEAVER, A. M. Regulation of cancer invasion by reactive oxygen species and Tks family scaffold proteins. Sci. Signal., v. 2, n. 88, p. pe56, 2009.

WILSON, D. F.; JIANG, D. J.; PIERCE, A. M.; WIEBKIN, O. W. Oral cancer: role of the basement membrane in invasion. Australian dental journal, v. 44, n. 2, p. 9397, 1999.

YAMAGUCHI, H.; LORENZ, M.; KEMPIAK, S.; SARMIENTO, C.; CONIGLIO, S.; SYMONS, M.; SEGALL, J.; EDDY, R.; MIKI, H.; TAKENAWA, T.; CONDEELIS, J. Molecular mechanisms of invadopodium formation: the role of the N-WASP-Arp2/3 complex pathway and cofilin. J. Cell Biol., v. 168, n. 3, p. 441-452, 2005.

YAMAGUCHI, H.; OIKAWA, T. Membrane lipids in invadopodia and podosomes: key structures for cancer invasion and metastasis. Oncotarget, v. 1, n. 5, p. 320-328, 2010.

YAMAGUCHI, H.; PIXLEY, F.; CONDEELIS, J. Invadopodia and podosomes in tumor invasion. Eur. J. Cell Biol., v. 85, n. 3-4, p. 213-218, 2006.

YURCHENCO, P. D.; AMENTA, P. S.; PATTON, B. L. Basement membrane assembly, stability and activities observed through a developmental lens. Matrix Biol., v. 22, n. 7, p. 521-538, 2004.

YURCHENCO, P. D.; CHENG, Y. S.; CAMPBELL, K.; LI, S. Loss of basement membrane, receptor and cytoskeletal lattices in a laminin-deficient muscular dystrophy. J. Cell Sci., v. 117, n. Pt 5, p. 735-742, 2004.

YURCHENCO, P. D.; O'REAR, J. J. Basal lamina assembly. Curr. Opin. Cell Biol., v. 6, n. 5 , p. $674-681,1994$.

YURCHENCO, P. D.; WADSWORTH, W. G. Assembly and tissue functions of early embryonic laminins and netrins. Curr. Opin. Cell Biol., v. 16, n. 5, p. 572-579, 2004a. 
YURCHENCO, P. D.; WADSWORTH, W. G. Assembly and tissue functions of early embryonic laminins and netrins. Curr. Opin. Cell Biol., v. 16, n. 5, p. 572-579, $2004 b$.

ZAMBONIN-ZALLONE, A.; TETI, A.; CARANO, A.; MARCHISIO, P. C. The distribution of podosomes in osteoclasts cultured on bone laminae: effect of retinol. $\mathbf{J}$. Bone Miner. Res., v. 3, n. 5, p. 517-523, 1988.

ZENG, X.; YANG, P.; CHEN, B.; JIN, X.; LIU, Y.; ZHAO, X.; LIANG, S. Quantitative secretome analysis reveals the interactions between epithelia and tumor cells by in vitro modulating colon cancer microenvironment. J. Proteomics, v. 89, n., p. 51-70, 2013.

ZIOBER, A. F.; FALLS, E. M.; ZIOBER, B. L. The extracellular matrix in oral squamous cell carcinoma: friend or foe? Head Neck, v. 28, n. 8, p. 740-749, 2006. 